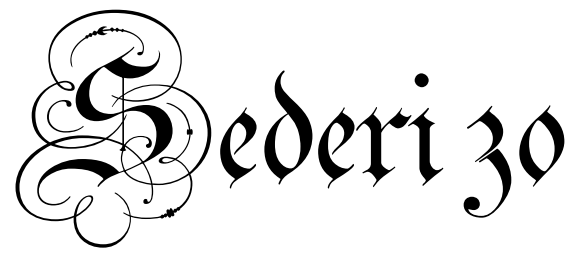

2020

EDITOR

A na Sáez-H idalgo

REVIEW EdITOR

M aría José M ora

Production Editors

Sara M edina Calzada

Tamara Pérez Fernández

M arta Revilla Rivas 
We are grateful to our collaborators for SEDERI 30:

Leticia Álvarez Recio (U. Sevilla, SP)

Antonio Bal lesteros (UNED, SP)

Gerd Bayer (University of Erlangen, DE)

Francisco J. Borge López (U. Oviedo, SP)

Gordon Campbell (U. Leicester, UK)

Marta Cerezo Moreno (UNED, SP)

Agustín Coletes Blanco (U. Oviedo, SP)

William Eamon (New Mexico State University, US)

Jonathan Gibson (Open University, UK)

Manuel Gómez Lara (U. Sevilla, SP)

Andrew Hadfield (U. Sussex, UK)

Sonia Hernández Santano (U. Huelva, SP)

Derek Hughes (U. A berdeen, UK)

Clark Hulse (U. Illinois at Chicago, US)

John Jowett (Shakespeare Institute, U. Birmingham, UK)

James Knapp (Loyola U., Chicago, US)

Gregory Kneidel (U. Connecticut, US)

Alberto Lázaro Lafuente (U. Alcalá de Henares, SP)

Philip Lorenz (Cornell U., US)

Zenón Luis Martínez (U. Huelva, SP)

Joseph Ortiz (U. Texas at El Paso, US)

Deborah Payne (American U., US)

José A. Pérez Díez (U. Leeds, UK)

José Mạ Pérez Fernández (U. Granada, SP)

Reme Perni (U. Alicante, SP)

Jonathan Post (U. Cal ifornia at Los Angeles, US)

Francesca Rayner (U. Minho, PT)

Jonathan Sell (U. Alcalá de Henares, SP)

R.F. Yeager (U. West Florida, US)

Cinta Zunino (U. Jaén, SP) 


\section{Gederizo (2020)}

\section{Table of contents}

\section{Articles}

Luis Javier Conejero-Magro

The School of Salamanca in the sixteenth century and the way kingship is canvassed in Shakespeare's Richard II

Isabel de la Cruz Cabanillas

The Secrets of A lexis in Glasgow University Library MS Ferguson 7

Joan Curbet Soler

Writing and weaving: The textual and the textile in Spenser's 1590 Faerie Q ueene, III.i

Irene Montori

Representing creation, experiencing the sublime: The Longinian tradition in Tasso and Milton

Katherine Romack

The romance of Nahum Tate's King Lear

91-115

Sonia Villegas López

Truth and wonder in Richard Head's geographical fictions

117-37

\section{Reviews}

Magdalena Cieślak, Screening Gender in Shakespeare's Comedies: Film and Television A daptations in Shakespeare's Comedies

(by Coen Heijes)

Neil Corcoran, Reading Shakespeare's Soliloquies: Text, Theatre, Film, and Efertpi Mitsi, ed., Troilus and Cressida. A Critical Reader

(by Jonathan P. A. Sell) $145-50$

Mark Hutchings, ed., The Changeling. A Critical Reader

(by Cinta Zunino-Garrido) $151-55$

María José Mora, ed., R estoration Comedy, 1671-1682

(by Sonia Villegas López) 
Charles Ney, D irecting Shakespeare in A merica. H istorical Perspectives

(by Víctor Huertas Martín)

Patricia Parker, Shakespearean Intersections: Language, Contexts, Critical Keywords

(by Zenón Luis-Martínez) 169-76

Ángel-Luis Pujante, Shakespeare llega a España: Ilustración y R omanticismo (by Jesús Tronch) $177-81$

\section{Performance Reviews}

West Side Story (2018-2020)

(by Víctor Huertas Martín) 183-88

A bout Sederi $189-90$

Submission guidelines $.191-92$

Style sheet and notes for contributors 193-95 


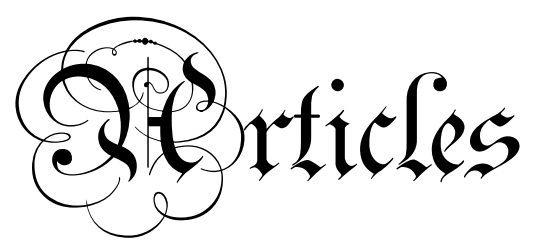





\title{
The School of Salamanca in the sixteenth century and the way kingship is canvassed in Shakespeare's Richard //
}

\author{
Luis Javier Conejero-M agro \\ U niversidad de Extremadura, Spain
}

\begin{abstract}
Although there appears to be no direct evidence that Shakespeare had access to the relectiones taught in the School of Salamanca during the sixteenth century, this study demonstrates that, forty years after their dissemination, the theories of Francisco Vitoria and his disciples were probably in circulation throughout England. The methodology in this article juxtaposes Shakespeare's Richard II with one of Vitoria's relectiones. This relectio modified the medieval idea of the divine origin of kingship, and generated a discussion about the origin of royal power which is central to the plot of Shakespeare's play.
\end{abstract}

KEYWORDS: Shakespeare; School of Salamanca; Richard II; kingship; AngloSpanish textual relations.

\section{La Escuela de Salamanca en el siglo XVI y el modo en que se obtiene la realeza en Richard II, de Shakespeare}

RESUMEN: Aunque parece que no existen pruebas de que Shakespeare conociera las relectiones que se enseñaron en la Escuela de Salamanca en el siglo dieciséis, este estudio demuestra que, cuarenta años después de su divulgación, las teorías de Vitoria y de sus discípulos se encontraban en circulación por Europa. La metodología de este artículo yuxtapone la obra de Shakespeare, Richard II, con una de las relectiones de Vitoria. Esta relectio cambió la idea medieval del origen divino de la majestad y generó un debate sobre el origen del poder real, que resulta tan importante para la urdimbre dramática de Shakespeare.

\section{A Escola de Salamanca no século XVI e a forma como a realeza é obtida em Richard II, de Shakespeare*}

RESUMO: Apesar de parecer não haver provas diretas de que Shakespeare tenha conhecido as relectiones ensinadas na Escola de Salamanca durante o século $X V I$, este estudo demonstra que, quarenta anos após a sua divulgação, as teorias de Vitoria e dos seus discípulos provavelmente se encontravam a circular por toda a Inglaterra. A metodologia deste artigo justapõe Richard II de Shakespeare a uma das relectiones de Vitoria. Esta relectio alterou a ideia medieval da origem divina da realeza e gerou uma discussão sobre a origem do poder real que é central para o enredo da peça de Shakespeare.

*Translation into Portuguese by Miguel Ramalhete.

(5) ederi 30 (2020): 7-28

https:/ / doi.org/ 10.34136/ sederi.2020.1 
PALABRAS CLAVE: Shakespeare; Escuela de Salamanca; Richard II; realeza; relaciones textuales anglo-españolas
PALAVRAS-CHAVE: Shakespeare; Escola de Salamanca; Richard II; realeza; relações textuais anglo-espanholas.

\section{Introduction}

One of the most quoted historico-political anecdotes concerning Shakespeare's Richard II is the well-known controversy generated by the performance of the play on the eve of the Essex Rebellion during Elizabeth I's reign. As Paul E. J. Hammer recounts, "on the afternoon of 7 February 1601 [...] the Lord Chamberlain's Men certainly staged a play 'of Kyng Harry [...] and of the kyllyng of Kyng Richard the Second' at the insistence of certain gentlemen who" paid Shakespeare's company forty shillings above the normal rate to perform the play $(2008,1)$. The identity of the play in question remains uncertain. However, the collective beliefs and experiences represented on stage were clearly considered to carry such literary weight as to convey a convincing argument for the legitimacy of Essex's cause to the audience, and therefore ultimately to the English people. The play must have been understood as a paean to the earl of Essex. As it transpired, on February $8^{\text {th }}$, Essex unsuccessfully marched on London with hundreds of armed men and was later beheaded. Almost a century later, in the 1680s, Charles II would suppress the controversial play (Kantorowicz 1957, 41).

It is acknowledged that Shakespeare "was working within a tradition of English history writing" (Hadfield 2004, 55) and therefore it is not difficult to draw a "parallel between the events of Richard's last years and those of the ageing queen" (Moseley 2009, 95). It would be pointless here to reiterate the details of this issue, which have been more than amply explored. It is nevertheless common knowledge that, when "in 1601 the historian William Lambarde was showing Elizabeth the fruits of his researches in the royal archives and arrived at the time of Richard II, [Elizabeth I] broke in: 'I am Richard II. Know ye not that? [...]'” (Moseley 2009, 95). Despite the rampant rumor that Elizabeth I had compared herself to Richard II, pace most scholars, this seems unlikely (Clegg 1999, 123). ${ }^{1}$ This disputed event serves to illustrate the tortuous

\footnotetext{
${ }^{1}$ For an in-depth study upon the representation of history during the Renaissance, see Woolf (2000), especially pages 32-35.
} 
paths of the knowledge transfer process, which can never be fully verified. As will be explained, this essay deals with comparative semiospherics in order to explain such knowledge transfer processes. What is not in question here is Shakespeare's interest in history and his concern with "the effects of government on the wider populace" (Hadfield 2004, 55). Indeed, his history plays frequently mirror current events. Richard II is a case in point, and a particularly revealing play as it "offers us a picture of an ideology of divine right kingship" when there was an "emerging divine right absolutist tone" (Lake 2016, 252 and 267) in England. As Richard van Oort affirms, "Shakespeare looks back to the old institution of kingship in order to look forward to the new social order in which each individual soul is elected" $(2006,330)$ and this is readily found at the core of Shakespeare's play.

As the dramatic scheme generally shows in Shakespeare's histories, the monarchs are in a quandary about their political attitudes, and their errors lead them to the realization that their ways of administering public policy are not entirely proper. For example, Richard II's form of government, and his belief in the teleological nature of power, shows that he firmly believes in the divine and unmediated right of kingship. This ideology of divine right arises at the very beginning of the play, when John of Gaunt, Richard's uncle, refers to the monarch as "God's substitute,| His deputy anointed in His sight" (1.2.37-38), ${ }^{2}$ and also in terms of Richard's own approach to governing. Richard II is outstanding among Shakespeare's history plays for multiple and varied arguments. Nevertheless, the play has been chosen as the focus for this article for one simple reason: it is the only history play where a truly "anointed king" is represented, even if Richard's belief in his divine status from a Christian standpoint cannot save him from being deposed (Hadfield 2004, 40). Indeed, as is the case with Richard II, it is fairly safe to assume that literature somehow reacts or responds-or even shapes our understanding of-history, as is clearly illustrated by the wideranging sources Shakespeare used to write his histories. ${ }^{3}$ This point

${ }^{2}$ All references to Richard II are from Charles R. Forker's The Third Arden Series Shakespeare edition $(2002,2014)$.

${ }^{3}$ It should be taken into consideration that there were multiple voices speaking from and about the past in the different texts where Shakespeare found inspiration for his plays. As Rackin states, "it is customary to speak of Shakespeare's sources by the names of individual authors (Hall, Holinshed, etc.) even though the chronicles 
is of the utmost importance when the literary power of the representation, driven by dexterity of language, modifies or represents in a particular way concepts as important for the compelling force of history as "kingship." Thus, kingship in Richard II is projected as a motivating force for the action.

This essay focuses on the depiction of kingship in Shakespeare's Richard II. It is proposed here that the way in which it is portrayed responds to the marked influence of emergent ideas about potestas and auctoritas, which suggested that power, though ultimately depending on God, lies within the natural right of the people and the community. ${ }^{4}$ These ideas were a product of the intellectual circle known as the School of Salamanca. In short, the new ideas formulated by this School in the sixteenth century on the origin of the authority of kingship had a strong influence on European culture. As a focus of scholastic thought, the Iberian Peninsula benefited from a number of university luminaries who were determined to challenge the political systems known up to that point. Most of these thinkers were disciples of Francisco de Vitoria (1483-1546), a Dominican friar who, alongside developing existing principles of natural justice, denounced the treatment inflicted by the European conquerors on the inhabitants of the newly discovered lands of the "Americas," and questioned the indisputable power of European rulers of the time through his ontological conception of the state. Ramón Hernández summarizes Vitoria's conception of the authority of kingship in the following terms:

Although the supreme source of power and authority lies in God, Vitoria is careful to point out that this is true in the sense that all created perfection [...] is a participation of the infinite perfection that is God [but] in nature lies the efficient cause or primary origin of all power, be it physical or moral, personal or social, or private or civil. (1991, 1042-43)

Hernández further states that

included the work of many writers-predecessors whose work was incorporated, successors who augmented the narratives after their authors' deaths, and collaborators at the time of their production" (1993, 23).

${ }^{4}$ For more information on the way Shakespeare treats politics in his plays see, in particular, Dollimore and Sinfield (1985); Spiekerman (2001); Alexander (2004); Hadfield (2004); Murley and Button (2006); Armitage, Condren and Fitzmaurice (2009); Green (2010) and Skinner (2014). 
Vitoria held firmly to the view that civil authority resides in the people and in the community [even though the] transmission or delegation of this power to the rulers is always problematic in cases in which broad popular participation is denied or not possible. $(1991,1043)$

In other words, the result of Vitoria's line of thinking was a radical change in the notion of the origin of kingship and power: "the human race had the right to choose a single ruler [...] as this power, as a natural right" belongs to the community or the res publica (1991, 1043-44). ${ }^{5}$ As Hernández has noted, the transmission to rulers is "problematic." Richard II offers a clear opportunity to examine the pathways, lines, and figures by which such transmission takes place.

By introducing this possible source of Shakespeare's representation of the monarch in the first part of his second tetralogy as a chance discovery, this article does not intend to proceed as an exercise in $\mathrm{New}$ Historicism, but some of its terminology will be certainly alluded to, and a further theoretical perspective will be extracted from comparative semiospherics. Borrowing from Stephen Greenblatt's well-known New-Historicist methodology for analyzing cultural process helps "to look less at the presumed center of the literary domain than at its borders, to try to track what can only be glimpsed" $(2001,4)$. Otherwise stated, it considers how the theories about sovereignty proposed by the School of Salamanca, the intellectual pinnacle of which is to be found in Vitoria's lectures or relectiones, enticed Early Modern writers such as Shakespeare to see kingship in a new light. However, the essay does not aim to present two separate, autonomous systems (those of Shakespeare and Vitoria) and then attempt to gauge how one represents the other. Instead, it aims to explore the dynamic exchange involved in these two layers of similarity and homology. This "theory of exchange", as Frank Romany glosses it, is a "two-way flow between text and society", where the "cultural artifacts are produced by "collective negotiation and exchange'," and where "the theatre enjoys a privileged ability to influence and shape the world it represents" (1989, 273). This collective negotiation and exchange of "powers," to use Greenblatt's term, which understands "power" as the mixed

\footnotetext{
${ }^{5}$ The Latin term res publica, as Hadfield correctly elaborates, "meant the 'public thing', but was most frequently translated as the "common weal' or 'commonwealth"' (Hadfield 2004, 8).
} 
motives of the Renaissance culture, reveals the "half-hidden cultural transactions through which great works of art are empowered," transactions which are described in terms of "the circulation of social energy" (Greenblatt 2001, 4-6). ${ }^{6}$ However, unlike most NewHistoricist studies, the current essay does not involve two clearly defined texts, ideally those of Shakespeare and Vitoria, but two distinct systems of signification, Shakespeare's play and Vitoria's postulate of the governing faculty of the people as opposed to a tyrant. It is therefore clearly beneficial here to bring comparative semiospherics into play.

The term semiospherics, borrowed from Yuri Lotman's study (2015), also in many ways broadly connected to the studies of New Historicism, encapsulates "communicative processes and the creation of a new information to be realized" (Lotman 2005, 207). This article uses the term semiosphere rather simplistically, if also intelligibly, to put into practice what Jonathan P. A. Sell casts as "the system of signification or meaning-making which is particular to a given group of individuals, united [...] at a given time and in a given space, be it social, geographical, and so forth," which is "constitutive of and constituted by ideology and its forms in an ongoing, bidirectional process of semiotic symbiosis" (2018, 55-56). Thus, the semiospheres considered here involve, on the one hand, the School of Salamanca and Charles V's court, where Vitoria's theories were born, and on the other, the English court at the time Shakespeare's oeuvre was originated, before and after James I's accession to the throne of England. The collective beliefs and ideological elements involve auctoritas, potestas, kingship and sovereignty. While the point of departure of the present essay is Vitoria's intellectual circle (the School of Salamanca), the argument focuses on Shakespeare's Richard II and the semiosphere in which the dramatist worked. The doctrines put forth by the School of Salamanca form the basis for comparison in order to shed some new light upon Shakespeare's history plays and their context.

\footnotetext{
${ }^{6}$ Lucy Munro's "Shakespeare and the uses of the past: Critical approaches and current debates" (2011) reviews the different historicist approaches to studying Shakespeare in the first decade of the twenty-first century. Munro confronts and differentiates between presentist approaches or $\mathrm{New}$-Historicism and Cultural Materialism.
} 


\section{The School of Salamanca and the English court}

The approach accompanying the new vision Shakespeare introduces into his plays is as innovative, and as much in tune with the new waves of humanism sweeping Europe, as the new theories on the subject proposed by the School of Salamanca. Drawing particularly on the new doctrine proposed by the Dominican friar Francisco de Vitoria, this School is acknowledged to have embodied a Copernican-style reversal in terms of traditional thought on the divine origin of auctoritas. ${ }^{7}$ Vitoria did not receive due acclaim or academic attention until the work of James Brown Scott in 1928, yet he is considered the father of the doctrine of popular sovereignty, ${ }^{8}$ an idea proposed in the sixteenth century, by which the medieval concept of the divine origin of kingship was radically modified. ${ }^{9} \mathrm{H}$ is conception of political power, mainly expressed in his relectio entitled De potestate civili (1528), reinterprets and clarifies the key issues binding the emerging Renaissance state. These include questions concerning necessity and autonomy, the origin and nature of the sovereign power, and the purposes or ends to which this power should aspire. According to Pablo Zapatero, who puts Vitoria's ideas about the origin of kingship in a nutshell, "the power of the monarch and that of the political community are not exclusive" because the "political power resides in the res publica while its exercise is vested in the monarch" and "the administration of power, or government, is conferred upon the ruler by the res publica." To put this another way, "power is limited" (Zapatero 2009, 225). It is precisely in this "mediation" of power, which is transferred from the res publica or the community to the ruler, ${ }^{10}$ where Vitoria's

\footnotetext{
7 According to Hernández (1991), Vitoria anticipated today's human rights and international law (1035-1042). Adolfo Sánchez Hidalgo recalls that "the importance of Francisco de Vitoria [lies in] the conceptualization of [the] subjective right, and consequentially, in the genesis of what would later be known as Human Rights" $(2015,181)$.

${ }^{8}$ For a recent monograph studying Vitoria, see Brunstetter and O'Driscoll (2017).

${ }^{9}$ For more information on Francisco de Vitoria and his theory on civil potestas and natural law, see Pugh (1953); Hernández (1991); Castilla Urbano (1992); Zapatero (2009); Iturbe (2012); Guzmán-Brito (2013); and Valenzuela-Vermehren (2013).

${ }^{10}$ Vitoria's conceptualization of the perfect or pure "community" is founded upon the "notion of self-sufficiency of political society" put forward by Aristotle and Thomas Aquinas (Valenzuela 2013, 98).
} 
thesis is so subversive. The absolutist idea of the divine figure of the king becomes redundant as the "naturally and divinely appointed power rests in the commonwealth" or the "common good," so that "the primary bearer of the public authority is the social body itself, which has received it from God" (Valenzuela 2013, 95). Therefore, the "philosophical or ontological conception of the state [...] is considered to arise from both natural and eternal laws," and is "the result of human will, consent, and legal enactment" (Valenzuela 2013 , 83). Together with Vitoria, based on the tenets of the prestigious School of Salamanca, Domingo de Soto, Francisco Suárez and Luis de Molina taught that in the natural subject and the "subjective" right of the people, theres publica, reside the potestas and the dominium to bestow auctoritas on the prince (Cruz Cruz 2013, 40).

Earlier formulations of the concept of kingship (Coleman, 2000), prior to the School of Salamanca, clearly influenced Vitoria's analytical relectiones. Around the fifth and sixth centuries, Cassiodorus considered the role of governor an object of scrutiny, at a time when other philosophers did not question, or even think about, the pre-eminence of the ruler (Brown Scott 1928). In thirteenth-century Spain, more properly the kingdom of Castile at that time, the literary patronage of Alfonso $X$ fostered works such as Siete Partidas (1256-1265) and Espéculo (1255-1260), which "examined the faculties of kings, counts and judges to enact legislation" and "emphasized the idea of kingly or princely power as [...] an essential part or member of a greater whole" (Valenzuela 2013, 95-97). Alfonso X's statutory codes would clearly influence some of the intellectuals from the School of Salamanca, like Sebastián Fox Morcillo in his D e regni regisque institutione (1556) and Soto in his De Iustitia et iure (1580). They were both disciples of Vitoria (Valenzuela 2013 , 96). However, the most direct source of scholastic influence on Vitoria came from one of his teachers in Paris, Jacques AImain, who instructed Vitoria in Aquinas' ideas of kingship, which were collected and analysed in Almain's works D e dominio naturali, civili et ecclesiastico and Tractatus de Libellus de auctoritate Ecclesia et Conciliorum general im (1512-1516) (Urdánoz 1960, 112-13).

This melting pot helped the Dominican theologian to initiate a major shift not only in Spanish political thought, but also throughout Europe, prompting questions around issues associated with modern political statecraft. This article points to a number of instances of 
confluence between the semiospheres of Vitoria's School of Salamanca on the one hand, and the English court at the end of the sixteenth and the beginning of the seventeenth centuries on the other. The first evidence of the dynamic transaction between these two semiospheres is closely related to the retinue of the Emperor Charles V. Indeed, it is accepted by most biographers of Vitoria that on June $19^{\text {th }}, 1534$, the Emperor attended one of his classes, while he was paying an imperial visit to the University of Salamanca (Castilla Urbano 1992, 366). The troubled relationship between Vitoria and the Emperor needs further explanation. After presenting his second relectio on the indigenous people of the "Indies," De iure belli or De indis, pars posterior (1539), which caused considerable tension at the court of Charles V, the Emperor "wrote a letter, dated N ovember 10, 1539 , to the prior of the Dominican monastery of Salamanca in which he expressed grave concern that some members of his community had called into question Spain's rights over the Indies." He "ordered the prior to collect the various writings and copies in question, send them to the court for further study, and [also] ordered that henceforth such matters were not to be raised or addressed in public" without his permission (Hernández 1991, 1040-41). In addition, Charles V had previously been familiar with Vitoria's texts by another route. Under the imperial auspices, on September $7^{\text {th }}$, 1530, the Empress had written to the Salamanca theologian on behalf of the Pope Clement VII, asking for advice and for an academic defense of the validity of the marriage between Catherine of Aragon (Charles V's aunt) and Henry VIII, who was gathering evidence to support the annulment of his marriage. This defense materialized some months later in the relectio Vitoria delivered in Salamanca, De matrimonio (1531) (Castilla Urbano 1992, 365-66). The paradoxical controversies around the relationship between Charles V and Vitoria would become less pronounced at the end of the Emperor's life, when Vitoria's disciple, Soto, became Charles V's confessor (Ramis Barceló 2018, 99). Vitoria's influence crossed the boundaries of Charles V's empire, and

extended to the universities of Coimbra, with Pedro Barbosa; of Paris, with Juan Maldonado; of Louvain, with Leonardo Lessio; of Dilingen, with Pedro de Soto and Gregory of Valencia; of Rome, with Francisco Suárez; of Mexico, with Alonso Veracruz and Bartholomew de Ledesma; and of Lima, with Juan Ramírez. (Hernández 1991, 1032) 
Furthermore, the principles discussed among the theologians of the School of Salamanca appear to have arrived in England in the first decades of the sixteenth century. Only three years after Vitoria's relectio, De potestate civili, was delivered in Salamanca (Castilla Urbano 1992, 365), sir Thomas Elyot practically rephrased the theologian's words in his well-known treatise The Boke $\mathrm{N}$ amed the Governour (1531), dedicated to Henry VIII. In this work, the humanist "defines public weal," what we would call "commonwealth," as a "body living compact or made of sundry estates and degrees of men, which is disposed by the order of equity and governed by the rule of moderation of reason" (quoted in Moseley 1998, 74; emphasis added). It is worth noting that, at the exact time Elyot was composing the Governour, he was serving as the ambassador to the court of Charles V (Donner 1951, 56). As noted above, the Emperor had met Vitoria and read some of the theses emerging from the School of Salamanca. It seems likely that in this environment Elyot also would have encountered Vitoria's work. Thus, the ideas formulated by Vitoria about the origin of the power of kingship had also brought about a seismic shift in English politics.

The second instance of the point of confluence between the semiospheres of the School of Salamanca and the English court involves a triangular relationship between the humanist George Buchanan, the monarch James I and Vitoria himself. Neither theology nor traditional Christian catechism entertained the least doubt that the power of kings and rulers came from God, especially after James I's publication and distribution of his defense of monarchy in his treatises Basilikon D oron and The Trew Law of Free $M$ onarchies (1598). In these works, the monarch affirmed that "a subject's duty was to obey the king because monarchy was the divinely ordained form of government" and "rebellion was never permitted" (1598, 165). Evidence that the situation in England in no way reflected James I's ideal conception of absolutist power includes the fact that he "made sure that his key works, [...] Basilikon D oron and The Trew Law of Free $M$ onarchies, were published in a new edition before he arrived in England in May 1603" (Hadfield 2003, 216). As a matter of fact, the monarch's "political reflections [...] were written in response to the arguments for regicide of his former tutor, George Buchanan, articulated in De jure regni apud Scotos (published 1579)" (Hadfield 2004, 93). Indeed, James I's tutor in Scotland, Buchanan, is very likely to have met Vitoria when both of them attended John 
Major's lectures on logic and theology at the University of Paris (Brodie 2012, 87-92). The Scottish humanist studied in Paris between the years 1520 and 1522, and later on between 1526 and 1537 (Brodie 2012, 40-46), and Vitoria lived in Paris between 1508 and 1522 (Castilla Urbano 1992, 364).

The third body of evidence indicating that the semiospheres of the School of Salamanca and the English court were in contact is provided by Francisco Suárez. ${ }^{11}$ Probably the most international intellectual of the School of Salamanca (Houliston 2013, 83-86), and one of the most precocious of Vitoria's pupils, Suárez was "chosen by Pope Paul V to respond to James's 0 ath of Allegiance," and immediately found himself "at the center of the seventeenth-century crisis of sovereignty." His work, D efen sio fidei Catholicae et A postolicae (1613) justified tyrannicide, "along with that other Jesuit text, Juan de Mariana's On the King and the King's Education (De Rege et Regis Institutione)" (Lorenz 2013, 39). Valenzuela recalls that Mariana, following the doctrines of Suárez and Vitoria, "limits royal power and establishes that both natural and positive law restricts such power" $(2013,94)$. In fact, Suárez justified mediated power and the potestas of citizens-counter to the absolutist authority supported by James I-in the following terms:

[...] it may become necessary for this prince to be directed, aided, or corrected in his own field of activity by a higher power that governs men in relation to a more excellent and an eternal end. In that case, the dependence, since such a superior power is concerned with temporal affairs, not in themselves nor for their own sake, but [as if they were bestowed] indirectly; and often an account of some other factor. (Suárez 1613, 668) ${ }^{12}$

\footnotetext{
${ }^{11}$ It is pertinent here to pay attention to Philip Lorenz's article, "Christall Mirrors: A nalogy and Onto-Theology in Shakespeare and Francisco Suárez" (2006), where he draws a close parallel between Suárez and Shakespeare.

${ }^{12}$ Although it seems that, for the purposes of this research, Suárez's Selections were published too late, as it is generally considered that most of Shakespeare's plays were written before 1610 and Richard II around the year 1595, "James knew of [Suárez's theses] beforehand through reports from his secret agent in Madrid, Sir John Digby" (Lorenz 2013, 39). It can therefore be concluded that the compelling force of Suárez's theories made it possible for his writings to circulate in society, even before they were published.
} 
The circulation of social energy radiating from Paris and Salamanca to London ${ }^{13}$ during the sixteenth and seventeenth centuries is confirmed and substantiated by James I's fear of regicide, based on Buchanan's arguments, as well as in his relentless persistence that the monarch was "divinely ordained" and that "rebellion" must not be "permitted." This was probably contrary to the situation in England in the decades before James's ascension to the English throne, as some texts attest, such as "An Homilie Against Disobedience and Wylful Rebellion." Part of the collection of Certain Sermons A ppointed by the Q ueen's M ajesty (1574), the Homily "adopts the absolutist position that no rebellion is ever permissible, however tyrannical the king" (Hadfield 2004, 43), an argument which was evidently adopted by James I later on. Actually, the Homily had been

composed in response to a series of events that threatened the stability of Elizabethan government; the last Tudor rebellion, the Northern Rebellion (1569-70), in favour of Mary Stuart's claim to the throne; the papal bull declaring Elizabeth to be illegitimate; and the execution of Thomas Howard, fourth Duke of Norfolk (153672), the leading Catholic courtier, for his part in the Ridolfi plot which aimed to install Mary as queen. (Hadfield 2004, 43)

Often reproduced and read by parsons and vicars at Sunday services, the Homily declares that "a rebel is worse than the worst prince, and rebellion worse than the worst government of the worst prince that hitherto hath been" (1574, 557).

There appears to be no further textual evidence indicative of Vitoria's writings being known in England at the time Shakespeare was writing Richard II. However, as has been demonstrated so far, this cultural transaction can be understood in terms of how the essence of Vitoria's theories was already circulating in society. The presence of Vitoria's text in England seems unlikely, particularly if we take into account that Vitoria was the very theological "lawyer"

\footnotetext{
${ }^{13}$ Vitoria's relectiones not only reached English and Scottish scholastic circles, they also penetrated the circles of seventeenth-century Dutch intellectuals and, later, eighteenth-century English philosophers. Thus, the "Dutchman, Hugo Grotius, in particular in his De Jure et Pacis, published in 1625, refers extensively to Vitoria and transcribes many of his paragraphs." Moreover, the work of Grotius "would influence John Locke and Samuel Pufendorf, who themselves would mark the reflection of the Encyclopedists and journal ists of the eighteenth century" (Hernández 1991, 1032).
} 
who was charged with producing the document condemning Henry VIII's attempt to legitimize divorcing his wife to allow him to marry Anne Boleyn. Nevertheless, the doctrine set out in Vitoria's De potestate civili must have had the occasional defender in England such as, no doubt, London's Erasmian circle. After all, Erasmus of Rotterdam knew Vitoria through his friend Luis Vives, who had been in Paris at the same time as the Dominican before "lectur[ing] in philosophy at Corpus Christi College, Oxford" and being "appointed tutor of Princess Mary, daughter of Henry VIII and Catherine of Aragon" (Morcillo et al. 2018, 121). This last evidence of the interconnected semiospheres of the School of Salamanca and the English court addresses the fact that Vitoria himself had been in contact with the circle of Erasmus when he became friends with Vives, who was in Paris between 1508 and 1512 (Hernández 1991, 1035). Indeed, Vives expressed his respect for Vitoria in a letter to Erasmus:

[Diego] has a brother who is different from him, Francisco de Vitoria, who is also a Dominican, a theologian of Paris. He is an individual of the greatest renown and credit among his brethren. Remember that on more than one occasion he defended your cause before different assemblies of theologians in Paris. He is very skillful in these scholarly argumentations. He has been successfully cultivating good letters since he was a child. (Erasmus 1960, 83-85)

It was in the middle of this political and intellectual turmoil that the university luminaries from the School of Salamanca, never for one moment doubting the principle sanctioned by the sacred texts of the Old and New Testament, developed these ideas and brought them to fruition, claiming that potestas, although of divine origin, was conferred on social entities or on the "collectivity," as these were the natural seat of political power (Cruz Cruz 2013, 40-43). From this arose the belief that the power God confers on a person is based on a teleological purpose, which is none other than the common good of the community or political entity (Valenzuela 2013, 84). Consequently, this does not involve "unmediated," but rather "mediated" power.

\section{Richard II, the perfect exemplum}

It is quite clear that the new doctrine on kingship, put forward by the School of Salamanca, and worded in such simple terms, would have 
consequences which would be characterized as "revolutionary." 14 This compelling force, and the circulation of the social energy of these doctrines, had an effect on the way kingship is represented and addressed in the first part of Shakespeare's second tetralogy, Richard II. Without jettisoning the spirit of historical drama, then, Richard II offers a complex view of kingship with broader historical implications. Here, Shakespeare superimposes a modern framework on a medieval setting, where the historical meaning can only be discerned in terms of a humanist perspective. He does this through a plot structure which is so close to the doctrine of Salamanca that the play will prove "revolutionary." It is not a coincidence that this play - or a very similar one, if it transpires that Shakespeare's Richard II was not the play in question-was chosen to be represented in London on the eve of the Essex Rebellion. As if it were extracted directly from the teaching of Vitoria's De potestate civili, which prefers a mediated power to a divine and unmediated authority, kingship at the end of Shakespeare's play is "no longer located in one place [or] one body" because "it is dispersed [as it] moves into mediation itself" (Lorenz 2006, 115). It is acknowledged that recognition of the mediating role, or the link between God as the source of all authority, and the king, the person with whom God deposits this authority, was a final blow to the medieval conception of kingship. It therefore also amounts to the end of one form of government and the beginning of a new one, or a change in the way politics is played, as we would say today. It goes without saying that all this has a corollary in the way the ruler relates to "the ruled," and in this deep transformation lies the key to explaining the dramatic representation of Richard II's attitude towards his subjects. ${ }^{15}$ Jean E. Howard makes a point which probably has most relevance for anyone studying Richard II, as opposed to any other play. She notes that Shakespeare does not "reflect but refracts political thought" (2006, 109; emphasis added).

Shakespeare's Richard II was recorded in the Stationer's register in London in 1597, coincidentally the same year Suárez's M etaphysical Disputations was published, and is still considered a

\footnotetext{
${ }^{14}$ As a matter of fact, the theory of kingship proposed in the sixteenth century is an embryonic form of sovereignty of the people, or democracy.

${ }^{15}$ Zenón Luis-Martínez refers to the "time of mourning" as "an inherent condition of kingship" $(2008,694)$ when he explains the complex character of Richard II.
} 
play which "posit[s] the theoretical and metaphorical crux of political-theological sovereignty" (Lorenz 2013, 34). The attitude and hence the language of Richard II is therefore commensurate with a monarch convinced of the validity of the old and widely accepted maxims that "the king is above the law" and "the king can do no wrong." However, although Richard is a tyrant at the beginning of the play, and thinks of himself as "the law-give[r] appointed by God, [who] therefore could not be subjected to the indignity of suit by his subjects" (Pugh 1953, 478-79), ${ }^{16}$ after his cousin Henry Bolingbroke's uprising, Richard is "no longer like God" (Lorenz 2006, 113) but a victim of his own wrongdoings. As Robert Miola correctly says, "Shakespeare [...] depicts Richard as both rightful anointed king as well as capricious tyrant" (2000, 46-47). In the first acts, when he assumes that his divine appointment exonerates him from responsibility, he actually believes that he is the "deputy elected by the Lord" (Richard II 3.2.57) because "Not all the water from the rough rude seal Can wash away the balm off from an anointed king" (3.2.54-55). Not only does Richard see himself as a quasi"almighty" ruler, but his relatives and members of the court corroborate this idea with their comments about the body of the king. His uncle York thinks of him as "the anointed King" (2.3.96), and the bishop of Carlisle, who is "a proponent of the ideology of sacred monarchy and divine right" (Lake 2016, 252), describes Richard as

the figure of God's majesty

His captain, steward, deputy elected,

A nointed, crowned, planted many years. (4.1.126-8)

Regardless of the extent to which Richard appears to be "elected by the Lord" (3.2.57), the change in the concept of kingship brought about by the turn of events in act four would seem to be borrowed from the theories of the School of Salamanca. At this moment in the play, when the social order flocks to support his cousin, Richard, who is dragged into what seems like a milites ex machina, reminds the rebels of the unmediated divine and everlasting character of his appointment and anointment. His insistence on comparing himself to Christ reveals the views which have defined his performance as a monarch and is exactly what Vitoria criticizes in his D e potestate civili.

${ }^{16}$ This is how Pugh summarizes the privileged status of the medieval monarch, as an absolutist monarchy of the nation state $(1953,478-79)$. 
Convinced that a king answers to God only, he compares the treason of the nobility, the army and even the Church to that of Judas, and sees himself as Christ: "So Judas did to Christ, but He in twelvel Found truth in all but one; I, in twelve thousand, none." (4.1.171-72) Thus, Richard not only considers himself a victim of treason but also likens his situation to that of the Supreme Victim, going far as to compare his deposition to the sacrifice of Christ himself on the cross, suggesting even further that his experience surpasses Christ's betrayal because his enemies,

some of you, with Pilate, wash your hands,

Showing an outward pity, yet you Pilates

Have here delivered me to my sour cross,

And water cannot wash away your sin. (4.1.239-42)

By comparing the attitude and conduct of the rebels to the behavior of Judas and Pilate, and by comparing his own suffering to the passion of Jesus, he is suggesting clearly that the treason perpetrated against him is greater than the betrayal of Christ himself. In this way, not only is Richard justifying his view of kingship, he is also warning his enemies that regicide of this caliber almost amounts to deicide, something very similar to James I's conception of sovereignty.

This act, along with much of the play, could have been written with Vitoria's words in mind. The correspondence between the rebels who force Richard's deposition and the doctrine proposed by Vitoria could not be more patent. The master of the School of Salamanca suggested in 1528 that:

civil laws are binding on legislators and principally on kings, [so that] a legislator who does not obey his own laws wrongs the res publica and all other citizens. [...] Although the laws be issued by the king, they are equally binding upon the king himself. (1960, 150)

To draw another parallel between Shakespeare's play and Vitoria's treatise: the theologian illustrated his idea on kingship by pointing to the deposition of Peter of Castile-called either the Cruel or the Just, depending on the source-by his bastard brother, Henry of Trastámara, who would later become Henry II of Castile (Castilla Urbano 1992, 125-26). 


\section{Concluding remarks}

The impact of the new political thought emanating from one of the most powerful countries in Europe at the time, and grounded in a naturalistic vision of political life, had an important bearing on how Shakespeare characterized his monarchs. This is particularly true of the protagonist of the first part of his second tetralogy, Richard II. The link between Shakespeare's play and this new doctrine of popular sovereignty developed in the School of Salamanca is not coincidental. As a matter of fact, both the intellectuals from Salamanca and Shakespeare himself focus their attention on texts or stories pertaining to the responsibility of the usurper or the tyrant, and this is directly related to Vitoria's conception of people's natural power over the king's alleged summa potestas. As van Oort suggests, "Shakespeare's kings are obsessed with the idea of their status as usurpers because they participate in the same resentment that makes it impossible for them to accept their invulnerability at the center." For Shakespeare, "usurpation is thus much more than a political category [as it] implies the awareness that the throne is in reality an 'aesthetic scene' that preexists the individual's place on it" (2006, 325). Both for Shakespeare and the School of Salamanca, the crucial deposition of the king points to a new political order and the decay of the Middle Ages. This change in how kingship is conceptualized is particularly evident in Shakespeare's history plays when, even from

the moment the anointed king is deposed, the self-laceration of feudalism has begun [as the] overthrow of the sacred institution of monarchy, and the general disorder in the ancient, "nature given" communal hierarchy which follows it, are the starting point of society's self-laceration. (Heller 1965, 20)

The supposed chaos followed by the deposition of a king is essential for the new era. There is little doubt that Shakespeare, "focusing on the highest matters of state in work after work, demonstrates a complex engagement with how the wheels of power turn" (DiMatteo 2011, 161), and this is very apparent in Richard II. This essay corroborates the fact that the link between Shakespeare's (re)presentation of kingship and the doctrine proposed by Vitoria and his disciples involves the new role given to the political community, the res publica and the state. 
The findings of this article help to illustrate that Vitoria's conceptualization of kingship and the role of public authority were interlocking issues involving the semiospheres of the School of Salamanca and the English court at the time Richard II was composed. In the light of Vitoria's theories on potestas and auctoritas, Richard II can be seen not only as prefiguring but also as responding to the new ontology of kingship. The rendition of the monarch in Shakespeare's play, and the way he is deposed, are depicted as analogous to the School of Salamanca's thesis on divineright sovereignty. Only in the light of the widely accepted medieval belief in the quasi-divine character of the monarch can the manner of discourse employed by Richard II be understood, as his royal monologue leaves no room for any dialogic interaction, let alone for any political dialogue. This is not to suggest that Shakespeare was cognizant of the relectiones brought forward by the School of Salamanca, or even of Francisco de Vitoria himself and his teachings in Paris or Salamanca. Instead we are faced with a "shared code, a set of interlocking tropes and similitudes that function not only as the objects but as the conditions of representation" (Greenblatt 1988, 277). Such "literary" space or the space of the trope is precisely what unites Shakespeare and Vitoria and where the concepts of auctoritas, potestas and dominium are conveyed. Where these two figures are held close in terms of each others' language demands further research and requires an even closer reading of their language.

The rhetorical and stylistic characterization of Richard II as a tyrant in the first three acts of the play, when he believes in his divine anointment, is what proves the social circulation of the theories of the School of Salamanca to be an essential component of the dramatic framework of Shakespeare's history. Simply put, this incipient and almost embryonic political dialogue resulting from the new doctrine proposed by the School of Salamanca entails an essential change in the mode of communication between political power and the political community, between rulers and ruled, between rex and res publica, and between monarchs and their subjects. The transformation of the concept of kingship is of such importance that it may even affect the language of literary works which represent the past, and whose representation is so relevant to the present. 


\section{References}

Alexander, Catherine M. S., ed. 2004. Shakespeare and Politics. Cambridge: Cambridge University Press.

Armitage, David, Conal Condren, and Andrew Fitzmaurice, eds. 2009. Shakespeare and Early M odern Political Thought. Cambridge: Cambridge University Press.

Brodie, Alexander. 2012. The Scottish Enlightenment. Edinburgh: Birlinn.

Brown Scott, James. 1928. El origen español del derecho internacional. Valladolid: Cuesta.

Brunstetter, Daniel R., and Cian O'Driscoll, eds. 2017. Just W ar Thinkers: From Cicero to the 21st Century. London: Routledge, Taylor \& Francis.

Castilla Urbano, Francisco. 1992. El pensamiento de Francisco de V itoria: filosofía política e indio americano. Barcelona: Anthropos.

Clegg, Cyndia. 1999. "Archival Poetics and the Politics of Literature: Essex and Hayward Revisited." Studies in the Literary Imagination 32: 115-32.

Coleman, Janet. 2000. A History of Political Thought: From Ancient Greece to Early Christianity. Oxford: Blackwell.

Corrie, George Elwes, ed. (1574) 1850. “A Homilie Agaynst Disobedience and Wylful Rebellion." In Certain Sermons: Appointed by the Queen's M ajesty. Cambridge: Cambridge University Press.

Cruz Cruz, Juan. 2013. "La translatio del poder and soberano-una teoría jurídico-política en el Siglo de Oro." M edievalia 16(2): 37-43.

DiMatteo, Anthony. 2011. “'Our sovereign process': Reading Shakespeare's Politics." College Literature 38 (2): 161-70.

Dollimore, Jonathan, and Alan Sinfield, eds. 1985. Political Shakespeare: N ew Essays in Cultural M aterialism. Manchester: Manchester University Press.

Donner, H. W. 1951. "The Emperor and Sir Thomas Elyot." The Review of English Studies 2 (5): 55-59.

Erasmus, Desiderius. (1960) 1992. O pus Epistolarum. Edited by P. S. Allen. Oxford and New York: Oxford University Press.

Forker, Charles R., ed. (2002) 2014. King Richard II. London: Bloomsbury, A rden Shakespeare Third Series, Thomson Learning.

Fox Morcillo, Sebastián. 1556. De regni regisque institutione. Antwerp: Gerard Speelman.

Green, Jeffrey. 2010. The Eyes of the People: Democracy in an Age of Spectatorship. Oxford: Oxford University Press.

Greenblatt, Stephen. (1988) 2001. Shakespearean N egotiations. Oxford: Oxford University Press and Clarendon Paperbacks. 
Guzmán-Brito, Alejandro. 2013. “Breve relación histórica sobre la formación y el desarrollo de la noción de derecho definido como facultad o potestad ('derecho subjetivo')." A rs luris Salmanticensis Estudios 1: 69-91.

Hadfield, Andrew. 2003. "Timon of A thens and Jacobean Politics." Shakespeare Survey 56: 215-26.

Hadfield, Andrew. 2004. Shakespeare and Renaissance Politics. London: Thomson Learning.

Hammer, Paul E. J. 2008. "Shakespeare's Richard II, the Play of 7 February 1601, and the Essex Rising." Shakespeare Q uarterly 59 (1): 1-35.

Heller, Agnes. (1964) 1965. "Shakespeare and History" (review of Shakespeare O ur Contemporary, edited by Jan Klott). N ew Left Review 1 (32): 16-23.

Hernández, Ramón. 1991. "The Internationalization of Francisco de Vitoria and Domingo de Soto." Fordham International Law Journal 15 (4): 1031-59.

Houliston, Victor. 2013. Catholic Resistance in Elizabethan England: Robert Person's Jesuit Polemic, 1580-1610. Aldershot: Ashgate.

Howard, Jean E. 2006. “Dramatic Traditions and Shakespeare's Political Thought." In British Political Thought in History, Literature and Theory 1500-1800, edited by David Armitage, 129-44. Cambridge: Cambridge University Press.

Iturbe, Mariano. 2012. "The Natural Law in the Times of St. Francis Xavier: Francisco de Vitoria (1492-1546)." In St Francis Xavier and the Jesuit $M$ issionary Enterprise. Assimilations between Cultures, edited by Ignacio Arellano and Carlos Mata Induráin, 71-89. Pamplona: Servicio de Publicaciones de la Universidad de Navarra.

James VI and I. (1598, 1616) 1971. The Works. New York and Hildersheim: Georg Olms Verlag.

Kantorowicz, Ernst H. 1957. The King's Two Bodies: A Study in M ediaeval Political Theology. Princeton, New Jersey: Princeton University Press.

Lake, Peter. 2016. H ow Shakespeare Put Politics on the Stage. London and New York: YaleUniversity Press.

Lorenz, Philip. 2006. "Christall Mirrors: Analogy and Onto-theology in Shakespeare and Francisco Suárez." Religion \& Literature 38 (3): 101-19.

Lorenz, Philip. 2013. The Tears of Sovereignty: Perspectives of Power in Renaissance D rama. N ew York: Fordham University Press.

Lotman, Yuri. 2005. “On the Semiosphere.” Translated by Wilma Clark. Sign System Studies 33 (1): 205-26.

Luis-Martínez, Zenón. 2008. “Shakespeare's Historical Drama as Trauerspiel: Richard II -And After." ELH 75 (3): 673-705. 
Morcillo, Aurora G., María Asunción Gómez, Paula de la Cruz-Fernández, and José Manuel Morcillo-Gómez, eds. 2018. The Modern Spain Sourcebook: A Cultural History from 1600 to the Present. London: Bloomsbury.

Moseley, Charles W. R. D. (1998) 2009. Shakespeare's H istory Plays: Richard II to Henry $V$, the Making of a King. London: Penguin Books and Humanities-Ebooks, LLP.

Munro, Lucy. 2011. "Shakespeare and the Uses of the Past: Critical A pproaches and Current Debates." Shakespeare 7 (1): 102-25.

Murley, John A., and Sean Button, eds. 2006. Perspectives on Politics in Shakespeare. Oxford: Lexington Books.

Oort, Richard van. 2006. "Shakespeare and the Idea of the Modern." N ew Literary History, Critical Inquiries 37 (2): 319-39.

Pope, Alexander. (1742) 1743. The Dunciad. Edited by George Faulkner. London and Dublin: M. Cooper at the Globe in Paster-N oster-Row.

Pugh, George W. 1953. "Historical Approach to the Doctrine of Sovereign Immunity." Louisiana Law Review 13(3): 476-94.

Rackin, Phyllis, and Jean E. Howard. 1997. Engendering a Nation: A Feminist A ccount of Shakespeare's English H istories. London: Routledge.

Rackin, Phyllis. (1990) 1993. Stages of H istory: Shakespeare's English Chronicles. Ithaca, New York: Cornell University Press.

Ramis Barceló, Rafael. 2018. “La presencia de Erasmo en las obras de Vitoria y Soto." Relectiones 5: 93-114.

Romany, Frank. 1989. "Shakespeare and the New Historicism." Essays in Criticism, A Q uarterly Journal 39 (4): 271-88.

Sánchez Hidalgo, Adolfo. 2015. “Voluntarism and Intellectualism in Francisco de Vitoria." Persona \& D erecho 73: 181-202.

Sell, Jonathan P. A. 2018. "Sleep and the Shepherd-king in Quevedo and Shakespeare: An Essay in Comparative semi ospherics." ELH 85: 55-84.

Skinner, Quentin. 2014. Forensic Shakespeare. Oxford: Oxford University Press.

Soto, Domingo de. 1580. De lustitia et iure. Salamanca: Excudebat Ioannes Baptista a Terranova.

Spiekerman, Tim. 2001 Shakespeare's Political Realism. Albany: State University of New York Press.

Urdánoz, Teófilo, ed. 1960. O bras de Francisco de V itoria. R elecciones Teológicas. Madrid: Biblioteca de Autores Cristianos.

Valenzuela-Vermehren, Luis. 2013. "The Origin and Nature of the State in Francisco de Vitoria's M oral Philosophy." I deas y V al ores 62 (151): 81-103. 
Vitoria, Francisco de. (1528) 1960. "De potestate civili, proposition 21." In O bras de Francisco de Vitoria. Relecciones Teológicas, edited by Teófilo Urdánoz, 107-290. Madrid: Biblioteca de Autores Cristianos.

Woolf, Daniel R. 2000. Reading History in Early M odern England. Cambridge: Cambridge University Press.

Zapatero, Pablo. 2009. "Legal Imagination in Vitoria - The Power of Ideas." Journal of the History of International Law 11 (2): 221-71.

How to cite this article:

Conejero-Magro, Luis Javier. "The School of Salamanca in the Sixteenth Century and the Way Kingship is Canvassed in Shakespeare's Richard II." SEDERI 30 (2020): 7-28.

https:/ / doi.org/ 10.34136/ sederi.2020.1

A uthor's contact: conejeroluis@unex.es

Postal address: Dpto. Filología Inglesa - Universidad de Extremadura - Avda. Universidad, s/ n. - 10071 Cáceres - Spain

Submission: 18/ 10/ 2019 A cceptance: 28/ 01/ 2020 


\title{
The Secrets of Alexis in G lasgow University Library M S Ferguson 7
}

\author{
Isabel de la Cruz-Cabanillas \\ U niversidad de A Icalá, Spain
}

This article deal s with a handwritten, hitherto unexplored copy of a printed text, The Secrets of Reverend A lexis of Piedmont, held in Glasgow University Library, MS Ferguson 7, which dates to 1565. The manuscript includes a collection of secrets by an anonymous compiler from the English translation of De' Secreti del reverendo donno A lessio de Piemontese, a highly popular book of secrets published in Venice in 1555 and immediately rendered into other languages, including English. The handwritten compilation proves to be a dynamic artifact which is personalized to suit the compiler's needs and ultimately becomes an independent new product.

KEYWORDS: early modern manuscript studies; Books of Secrets; MS Ferguson 7; Secrets of A lexis of P iedmont; Girolamo Ruscelli; William Warde.

\section{The Secrets of Alexis \\ del M s Ferguson 7 de la Biblioteca de la Universidad de G lasgow}

RESUMEN : Este artículo analiza una copia manuscrita inédita del texto impreso The Secrets of Reverend A lexis of Piedmont, conservada en la Biblioteca de la Universidad deGlasgow, Ms Ferguson 7, fechada en 1565. El manuscrito incluye una colección de secretos por parte de un compilador anónimo extraídos de la traducción inglesa de $D e^{\prime}$ Secreti del reverendo donno A lessio de Piemontese, un libro de secretos muy popular publicado en Venecia en 1555 y que se tradujo inmediatamente a otras lenguas, entre ellas a inglés. La re copilación manuscrita resulta ser un artefacto dinámico que se personaliza para atender a las necesidades del compilador y que finalmente se convierte en un producto nuevo eindependiente.

PALABRAS CLAVE: cultura manuscrita de la época moderna temprana; Libros de

\section{The Secrets of Alexis \\ no MS Ferguson 7 da Biblioteca da Universidade de G lasgow*}

RESUMO: Este artigo analisa uma cópia manuscrita inédita de um texto impresso, The Secrets of Reverend A lexis of Piedmont, que se encontra no MS Ferguson $7 \mathrm{da} \mathrm{Bi-}$ blioteca da Universidade de Glasgow, e que data de 1565. O manuscrito inclui uma coleção de segredos elaborada por um compilador anónimo a partir da tradução para inglês de $D$ e' Secreti del reverendo donno A lessio de Piemontese, um livro desegredos al tamentepopular publicado em Veneza em 1555 e imediatamente traduzido para outras línguas, incluindo o inglês. A compilação manuscrita demonstra ser um artefacto dinâmico, personalizado de modo a servir as necessidades do compilador, etornandose, em última análise, num produto novo e independente.

PALAVRAS-CHAVE: cultura manuscrita da idade proto-moderna; Livros de Segre-

*Translation into Portuguese by Miguel Ramal hete. ederi 30 (2020): 29-46

https:/ / doi.org/ 10.34136/ sederi.2020.2 
secretos; Secrets of Alexis of Piedmont; Girolamo Ruscelli; William Warde. dos; Secrets of Alexis of Piedmont;

Girolamo Ruscelli; William Warde.

\section{Introduction}

In the early modern period, a large assortment of how-to books became popular. Thus, technical books, such as collections of recipes, household management volumes, and instructional medical texts experienced an increasing demand. Of thesevarious medical writings, collections of recipes, experiments, and secrets ${ }^{1}$ flourished in the sixteenth and seventeenth centuries.

The three kinds of texts-recipes, experiments, and secrets-share structural features that identify them as belonging to the recipe genre. In fact, the definition provided by Sara Pennell and Michelle DiMeo for recipe books could apply to any of the three. ${ }^{2}$ According to Francisco Alonso-Almeida (2013) and Isabel de la Cruz-Cabanillas (2017), recipes in the Early Modern English period usually havea title, which indicates the purpose. After this, a verb in the imperativemood introduces the ingredients to be used, followed by the method of preparation. The dose and duration of the treatment may also be present in medical remedies. Finally, there may be an efficacy phrase stating the validity of the preparation. Thus, the recipe genre encompasses all these types of texts, regardless of whether they could be classified specifically as a recipe, an experiment, or a secret. Therefore, the term recipe is also used to refer to secrets here.

The purpose of this article is to examine a thus-far unexplored manuscript copy from the printed English version of The Secrets of Reverend Alexis of Piedmont, which is located at Glasgow University Library MS Ferguson 7. The handwritten compilation proves to be a

\footnotetext{
${ }^{1}$ According to Eamon, secrets cannot be interpreted as "The lore of ancient sages or magi, but recipes, formulae, and 'experiments', often of a fairly conventional sort, associated with one of the crafts or with medicine: e.g., quenching waters for hardening steel, recipes for dyes and pigments, instructions for making drugs, and 'practical alchemical' formulae such as a jeweller or tinsmith might use" $(1985,27)$. For further details on the book of secrets, see Eamon (1984; 1985).

2 "A recipe book, whether printed or manuscript, is one which collects together and communicates information about the preparation of foodstuffs, drink, medications, cosmetics, household substances and other materials, including veterinary treatments, paints and occupationally specific materials (for example, lacquers)" (Pennell and DiMeo 2013, 6).
} 
dynamic artifact which is personalized to suit the compiler's needs and ultimately becomes an independent new product.

\section{The Secrets of Alexis of Piedmont}

After it was first published in Italian in 1555, The Secrets of A lexis circulated widely in print, as attested by its numerous reprintings in Italian and translations into several languages. According to William Eamon (1994, 140), only four years after its publication, there were already 17 editions of the work. This spectacular trend continued; from 1559 to 1569, it was printed 28 times, and 13 more in the following decade. No wonder this bestseller was the perfect candidate to be rendered into other languages. Thus, the text was translated profusely. In fact, Eamon $(1994,252)$ records 104 editions and translations between 1555 and 1699. Furthermore, Ad Stijmann (2012, 36-47) offers details of up to 269 editions from 1558 to 1999, including the Italian editions as well as the Catalan, Danish, Dutch, English, French, German, Latin, Polish, and Spanish versions. ${ }^{3}$

In discussing the relevance of the book, according to Eamon, "Alessio's most important contribution to early modern science was not his compilation of experiments but his discovery that publishing secrets was ethically superior to concealing them from the unworthy" $(2011,45)$. British printers and translators must have been of the same opinion, since the first translator of the work into English, William Warde, claims in his epistle to Lord Russell:

I have taken in hande to translate this noble and excellent worke called. The Secretes of the reuerende Maister, Alexis of Piemount, firste written in the Italian tongue, and after tourned into Frenche, and of late into Dutche, and nowe last of al into English, because that as well Englishemen, as Italians, Frechmen or Dutchmen, maye sucke knowledge and profit hereof. (Piemontese/ Warde 1562a)

Who the author of the book of secrets was is a moot issue. Stijnman $(2012,32)$ mentions that while most scholars take for granted that Alessio de Piemontese was a pseudonym for the Venetian humanist Girolamo Ruscelli, some authors disagree. Eamon claims that

\footnotetext{
${ }^{3}$ For Spanish translations, see Rey-Bueno (2005) and Saguar-García (2012); Polish versions as well as editions in other languages have been revised by Bela (1999), and Ferguson studied different English editions (1959).
} 
Ruscelli's involvement was "in all probability as its editor and not as the original author" (1994, 140). In turn, Ferguson $(1906,22)$ rejects Ruscelli's authorship. ${ }^{4}$ Regardless of who theoriginal author was, this study's focus is the handwritten version in MS Ferguson 7 with the purpose of investigating the motivations behind the copy, the compiler's concerns, and the use of the manuscript as a living artifact that could be personalized.

\section{The Secrets of Alexisin M anuscript Ferguson 7}

\subsection{Physical description of the manuscript and its contents}

The manuscript under scrutiny is referenced as GB 247 MS Ferguson 7. It is part of the collection of John Ferguson, Chemistry professor at the University of Glasgow from 1874 to 1915. Ferguson's personal library was extensive, containing approximately 18,000 volumes. After his death an important part of his collection was purchased by Glasgow University in 1921 . The collection is made up of ca. 500 manuscripts and ca. 7,500 printed books datable from 1363 to 1864. The volumes in the collection are mainly about chemistry, alchemy and medicine. The manuscript under study comes from Ferguson's personal library and has been in Glasgow University Library for almost a century now.

It is a bound volume of 64 folios, which measures $22.2 \mathrm{~cm}$ by 15.2 $\mathrm{cm}$ and is written on wove paper with no watermarks. The paper has been lined in pencil. Ruling serves not only to write above each line, but also to delimit the physical boundaries of the text, since all the margins have been clearly marked. The date of composition is the second half of the sixteenth century, as the dates 1565 and 1578 have been written in the manuscript (fol. $1 \mathrm{r}$ and fol. $23 \mathrm{r}$, respectively). The original card boards are now contained in nineteenth-century decorated boards with maroon leather spine, on which the title is printed in gold.

\footnotetext{
4 "The ascription of the work to Ruscelli, will not bear examination, for it leads to two quite incompatible narratives of the origin of the book and as they both necessarily emanate from him, if he be the author, hemust, in oneor other, if not in both, have been strictly inaccurate. For my own part I have seen no evidence that Ruscelli was the author, but only the assertion of Muzio, which has been followed by later writers" (Ferguson 1906, 22).
} 
The text is written in one column in a sixteenth-century secretary hand, as can be deduced by the shape of its most representative letters: "a single-lobbed" $\langle a\rangle$, "the flat-top open laid" $\langle g\rangle$, as explained by Jean F. Preston and Laetitia Yeandle (1999, vii); letter <e> with several types co-existing “including Greek e, open reversed e, and two-stroke e" (Petti 1977, 17) and the letters $\varangle m>$ and $\triangleleft n>$ with angular angles. The latter easily mistaken for $\varangle>$, since in the secretary hand, most writers usual ly make no distinction between one and the other. Other characteristically shaped letters are the forms of $\langle>$ and $\langle s\rangle$. The former is depicted as a twin-stemmed form, a number 2 format and as "a left-shouldered version" (Petti 1977, 17). Regarding letter «\$, "every writer of the secretary hand systematically employs two radically different types of s- one used initially and medially, the other terminally" (Dawson and Kennedy-Skipton 1966, 15). In MS Ferguson 7 both types are found, the long $<>$ and a kind of sigma type in final position.

The manuscript is divided into two sections: The first one contains part of "The Secretes of ye most reuerend maister A lexis of piemount $1565, " 5$ beginning on folio $1 \mathrm{r}$ and finishing on folio $20 \mathrm{v}$ with "Finish medicamentorum at aliorum è libro magister Alesivs de piedmont." However, the recipes continue from folios $21 \mathrm{r}$ to $22 \mathrm{v}$. For that reason, The Secrets of A lexis is assigned folios $1 r$ to $22 v$ in the online Glasgow University Library catalogue. The other item included in the same manuscript is an herbal that occupies folios 23r to 63v: "Taken out of D. Rembert dodoens phisitian to ye Emp. his herball made anno domini 1578."

Most likely, the intention of the MS Ferguson 7 compiler was to make a copy for personal use selecting material from two printed volumes and adapting the contents, the spelling and other linguistic matters. This practice can be seen in both texts. In the case of the Herbal, the compiler systematically summarizes the detailed information provided by Rembert Dodoens (1578) copying only the medical application of the herb in a recipe format.

Regarding the other item, The Secrets of A lexis, the recipe collection was also gathered from a printed book and shaped to the writer's own taste. Overall, the differences between the printed English version to

\footnotetext{
${ }^{5}$ When present in the manuscript, superscript letters have been preserved, whereas abbreviations have been silently expanded for clarity sake.
} 
which the compiler would have had access and the handwritten copy are diverse in nature. The compiler in MS Ferguson 7 copied only some secrets to shape them to his needs omitting others. Could it be said that this kind of manuscript indicated the shift from the printed text to a new piece of work which had a distinctive author, content, structure, and readership? ${ }^{6}$

\subsection{The Book of Alexis in Warde's edition versus MS Ferguson 7 version}

Each recipe included in the manuscript has been identified in Warde's translation and compared to the printed text. For collation purposes, therevised version of Warde's first part has been used for comparison (1562a). Likewise, the printings of the second (1563) and third parts (1562b) have been employed for collation purposes. ${ }^{7}$

In terms of quantity, the text in MS Ferguson 7 differs from the printed text, as it only reflects a small portion of the original work. The first part of the original opens with an epistle to Lord Russell by Warde, which was not recorded in the manuscript. Nor does the MS Ferguson 7 author include any information on the life of Don Alexis, which was provided to the reader in the section that preceded the first book entitled $D$ on A lexis vnto the gentle reader. Then, the first book is introduced with "the maner and secrete to conserue a mans youth, and to holde back olde age: and to maintaine a man al wayes in health and strength, as in the fairest flower of his age" (1562a, 1). On the whole, the first part of The Secrets of A lexis is organized into six books

\footnotetext{
${ }^{6}$ Barbierato explores the implications of this practice, which entailed "the ubiquitous decontextual ization every reader constantly made, thus creating a gap between the text and its reception that concerned even the most orthodox texts" (2011, 275-76). He even adds that "the copying process offered everyone the freedom to adapt the writings as they wished. They could select portions of the text, summarize it, insert personal considerations, amplify it, provide it with iconography or a new division in chapters, and modify its structure. Thus, the text was not simply duplicated, but ran the risk of becoming something else. Peoplewho undertook the copying for themselves, therefore, had the chance to shape it to their own needs" (2011, 268-69).

7 The fourth part was eventually discarded after it was confirmed that none of the secrets in this final part were included in the manuscript. This is in line with the date provided by the compiler at the beginning of the manuscript, since the fourth part was not published in English until 1569, when Richard Anbrose translated it directly from Italian.
} 
containing an uneven number of recipes each, the distribution of which can be seen in Table 1:

\begin{tabular}{|l|l|c|}
\hline & TOPIC & $\begin{array}{c}\text { NUMBER } \\
\text { OF RECIPES }\end{array}$ \\
\hline Book i & Medical recipes & 108 \\
\hline Book ii & Oils and waters & 78 \\
\hline Book iii & Preserves & 11 \\
\hline Book iiii & Cosmetics: waters, ointments, dyes, etc. & 54 \\
\hline Book v & $\begin{array}{l}\text { Alchemical recipes: dyes and metallurgical } \\
\text { processes }\end{array}$ & 64 \\
\hline Book vi & Alchemical recipes & 35 \\
\hline
\end{tabular}

Table 1: Recipes in the first part of the Secrets of A lexis

On the one hand, as shown in Table 1, the number of remedies in Warde's translation of the first part of the Secreti del reverendo donno A lessio de Piemontese totals 350. On the other hand, disregarding the other recipe collection (20r-22v), within the limits established by the scribe for the work, MS Ferguson 7 records 194 recipes, of which 50 were directly selected from the first part of The Secrets of A lexis (fols $1 r-9 r)$. This means that the 144 remaining secrets mainly come from the second and third parts. A breakdown of the recipes in the second and third parts of the original Secrets of A lexis is shown in Table 2.

\begin{tabular}{|c|c|c|c|}
\hline & \multicolumn{2}{|l|}{ TOPIC } & $\begin{array}{l}\text { NUMBER } \\
\text { OF RECIPES }\end{array}$ \\
\hline $\begin{array}{l}\text { Second } \\
\text { part }\end{array}$ & \multicolumn{2}{|c|}{$\begin{array}{l}\text { Medical recipes; oils and waters and several } \\
\text { alchemical recipes }\end{array}$} & 362 \\
\hline \multirow[t]{6}{*}{$\begin{array}{l}\text { Third } \\
\text { part }\end{array}$} & Book i & $\begin{array}{l}\text { Medical recipes and alchemical } \\
\text { recipes for metals }\end{array}$ & 413 \\
\hline & Book ii & To remove spots & 16 \\
\hline & Book iii & Alchemical recipes: dyes & 23 \\
\hline & Book iiii & Alchemical recipes to gild and to dye & 17 \\
\hline & Book v & $\begin{array}{l}\text { Alchemical recipes to separate metals } \\
\text { (gold, silver, copper and others) }\end{array}$ & 33 \\
\hline & Book vi & Oils and waters & 32 \\
\hline
\end{tabular}

Table 2: Recipes in the second and third parts of The Secrets of A lexis

The second part contains 362 secrets and the third part includes 534. The number of recipes in the two parts totals 896. Of these, 55 
secrets in MS Ferguson 7 were taken from the second part (fols 9r$14 r$ ), while the remaining 89 belong to the third part (fols $14 r-20 \mathrm{v}$ ). Again, the handwritten copy records only a small portion of the content included in the second and third parts. On the whole, of the 1,246 recipes in the original publication, approximately $15.5 \%$ of them are included in the manuscript.

The compiler of MS Ferguson 7 shows a preference for medical remedies, some of which must have been of special concern to the scribe, while others have been completely ignored. The medical recipes were for common troublesome diseases in the sixteenth century. Thus, there are remedies for discomfort in the eyes, toothache, sores, burns, abscesses, bladder stone, intestinal worms, inflammations of the skin, cough and other respiratory ailments, the plague and other disorders, such as king's evil, epilepsy, etc. The treatments may be presented in a solid, semisolid or liquid form. Along with pills, plasters and medicinal drinks, some ointments, such as "A noyntm ${ }^{t} y^{t}$ healith all burning $w^{t}$ fyre not leauing any scarre" on fol. $1 r$, and oils like "To make oyle of brimstone, to heale all manner of cankers-diseases or sores $w^{c}$ com of a putrified humor, $\&$ run continnuallye, called fistules, and also to heale ould wondes" on folio $1 \mathrm{v}$, are also included. In the second and third parts, there are instructions to make inks and dyes, to remove difficult stains, to produce remedies to improve memory, to kill fleas and lice, as well as to create medicines for a great variety of common ailments. Here the same tendency is followed in the selection of the material, inasmuch as most secrets are medical remedies.

In addition to Warde's preface and Don Alessio's biographical account mentioned above, the MS Ferguson 7 scribe also omits the secrets to purge evil humours (Piemontese/ Warde 1562a, 5), a remedy to "heal all maners of Pockes" (Piemontese/ Warde 1562a, 6), "To dissolue and reducte gold into a potablelicoure" (Piemontese/ Warde 1562a, 7), "To heale an excrescens or growing vp of the fleshe, within the yarde of a man" (Piemontese/ Warde 1562a, 8). In fact, the first secret selected comes from Warde's page 9: "To heale al maner of inflamation and euil disposition of the liver, and by this small secrete haue been healed certaine persons, which had their faces as it were Leparie, great swollen legges, theyr handes inflamed, and rough within syde." Likewise, in the second part, after omitting the first 38 recipes, the first secret that is copied down is taken from page 6: "To 
make a glew or paste $\mathrm{y}^{\mathrm{t}}$ holdeth as fast as a nayle" (MS Ferguson 7, fol. 9r).

The MS Ferguson 7 scribe thus clearly is selective, choosing the material of interest following the order in which the secrets are arranged in Warde's translation; that is, some recipes may be skipped, but no information from previous pages ever appears. Does this mean that there was a premeditated plan about which secrets should be copied down and which were to be left out of the handwritten copy? $\mathrm{No}$ evidence of this is found in the manuscript.

\subsection{The scribe's identity}

Although most recipes in The Secrets of A lexis are of a medical nature, the first part of the book was of interest to craftsmen and artisans, as well as beauty lovers, since it was one of the first works to pay extensive attention to different beauty treatments, as well as dyes and inks. However, the compiler of MS Ferguson 7 includes very little of this information, as can be seen in Table 3:

\begin{tabular}{|c|c|c|c|}
\hline & & $\begin{array}{l}\text { SECRETS OF } \\
\text { ALEXIS }\end{array}$ & $\begin{array}{c}\text { MS } \\
\text { FERGUSON } 7\end{array}$ \\
\hline \multirow[t]{4}{*}{$\begin{array}{l}\text { Cosmetic } \\
\text { recipes }\end{array}$} & $\begin{array}{l}\text { Skin treatments to remove spots, } \\
\text { wrinkles }\end{array}$ & 4 & 4 \\
\hline & Hair treatment (e.g. dyes) & 12 & 0 \\
\hline & Tooth, gum, breath treatments & 7 & 0 \\
\hline & Other facial and skin treatments & 28 & 2 \\
\hline \multirow{5}{*}{$\begin{array}{l}\text { Technical } \\
\text { recipes }\end{array}$} & Alchemical products & 14 & 0 \\
\hline & Paints, pigments, dyes, ink & 59 & 6 \\
\hline & Metallurgical products & 16 & 0 \\
\hline & $\begin{array}{l}\text { Miscellaneous (glue, artificial } \\
\text { amber) }\end{array}$ & 25 & 0 \\
\hline & Perfumes, oils, soap, pomanders & 77 & 4 \\
\hline Total & & $242^{8}$ & 15 \\
\hline
\end{tabular}

Table 3: N umber of cosmetic and technical recipes in the first part of The Secrets of Alexis and MS Ferguson 7

A lack of interest in perfumes, soaps, and other beauty products like waters contained in books two and four, as well as the cooking

\footnotetext{
${ }^{8}$ Theinformation for this column has been adapted from thetablein Eamon and Paheau (1984, 336).
} 
recipes in book three, can be observed by looking at Table 3 . This fact could indicate that the author was a man rather than a woman. One must also take into consideration the masculine and feminine roles of the period, where women were responsible for the care of the household, which entailed not only looking after sick people in the domestic environment but also supervising cooking matters. This omission of secrets about cosmetics and cuisine leads to the conclusion that the compiler very probably is a man rather than a woman. In fact, the compiler entirely ignores the section from book three on preserving food. The cooking recipes are for how to confit oranges and citrons, to confit peaches, quinces, melons, walnuts and gourds, among others. The scribe in MS Ferguson 7 does include some oils, though. Sometimes, these oils serve a medical purpose, such as a myrrh oil to purge humors (MS Ferguson 7, fol. 7v), but at times the medical purpose cannot be clearly deduced from the text, as in:

Oyle of Jasemyne and Violettes

Takeswete almondes well pilled and brayed, the floures of Jasemyne as much as you will, and laying them ranke vpon ranke, you shall leaue them in som moist place $\mathrm{x}$ dayes togither or more, then take them away and presse out $y^{e}$ oyle in a pressour, the virtue of the $w^{c}$ oyle serueth for diuers thinges: In ye lyke manner may you haue oile of violettes and oyer floures. (MSFerguson 7, fol. 7v)

\subsection{Linguistic personalization}

In addition to the topics and number of recipes selected, the personality of the scribe can be further deduced from two other features of the manuscript: his linguistic preferences and orthography. First of all, when the title in Warde's edition is too long, the scribe in MS Ferguson 7 shortens it, as in " $A$ very goodlie secrete to dye or colour woode, of what colour a man will, which some joyners do vse that make tables and other thinges of diuers colours and do esteme it amonge them selues to be of such excellencie, that one brother will not teache it another" (Piemontese/ Warde 1562a, 86), which is rendered in the manuscript as: "A very goodly secrete to dye or colour wood, of what colour a man will" (MS Ferguson 7, fol. 8r).

Likewise, the scribe tends to simplify coordinated synonymic nouns to keep only one of them. Thus, griefe disappears in "Pylles of mayster Michaell a Scot, the which heale the griefe or payne of the 
heade, be it inueterate or recent, purge the brayne, clarifye the syghte, cause a man to haue a good memorye, good colour in the face, and be also very good for many infirmities" (Piemontese/ Warde 1562a, 33), which is reproduced as: "Pilles of $\mathrm{m}^{r}$ mighell a scott, $\mathrm{w}^{\mathrm{c}}$ healethe pain of the head, be it inweterate or recent, purg the brayne, clarifie the sight, cause good memorye, good colour in the face, $\&$ be also good for many infirmities" (MS Ferguson 7, fol. 4v). Similarly, ciatrice as a synonym of skarre is not present in the title in MS Ferguson 7: "A synguler ointment, whiche healeth all burnynges wyth fyre, not leauing any cicatrice or skarre where it hath been" (Piemontese/ Warde 1562a, 9), which is rendered as: "Anoyntm" $\mathrm{y}^{\mathrm{t}}$ healith all burning $w^{t}$ fyre not leauing any scarre" (MS Ferguson 7, fol. 1r).

This simplification not only occurs in the titles, but also in the selection of the recipes and in the contents. When there are two secrets for the same disease, the scribe renders the shorter one. Likewise, the author of MS Ferguson 7 often summarizes the contents of the secrets. For example, the secret "To kill and destroy fleas" in the original text reads as follows:

Take white Elebore, and steepe it in milke or sodden wine, then put to it Auripigmentum, otherwise called Arsenick or orpine, \& sprinkle your house with it, and you shall destroyeall the flees. Also the decoction of Eldern cast about the house worketh the like effect. (Piemontese/ Warde 1563, 22)

However, the MS Ferguson 7 scribe reduces the recipe to simply "Make a decoction of elderne \& cast about in the howse" (MS Ferguson 7, fol. 11v). In a similar fashion, in another remedy for the same problem, the original "Take Penniriall when it is in Blossome, and burne it where the flees be, and the smell of that wyll kyll and destroy them" (Piemontese/ Warde 1563, 22) has been turned into "Take penyeriall when it is in blossom \& burn it when they be" (MS Ferguson 7, fol. 11v).

This explains why it is not al ways easy to trace the original recipe. The titles do not always resemble the original, inasmuch as, when there was a previous remedy for the same disease, the title of the recipe in the manuscript reads simply another. Moreover, especially in the second and third parts, the compiler tends to read the contents, internalize them, and come up with a new linguistic formulation in the word order, paraphrasing the sentences and choosing his 
preferred terms. Thus, in the third part of the book, one of the recipes "to make lutum sapientiae" reads as follows:

Take Potters earth very cleane two partes, horse dong one part, a lytle pouder of a Bricke, and the fylyng of yron, and a plaster of quicke lyme: and mingle it with salte water, and the yelke of egges: and make therof a paste for to lute or clay pots withall. Or elles take drie earth, and stampe it small, and sifte, it cast vpon it some wheate flower rancke vpon rancke, and than the yelkes of Egges and Winaigre, and mingle all together. Than playster or lute glasses, pottes or limbeckes with it, and drie them in the shadowe, and they will neuer faile nor brake in the fyer. You maye also mingle it with Oxe bloode in steede of water, it is also good for that purpose. (Piemontese/ Warde 1562b, 68)

In MS Ferguson 7, the first part of the recipe has completely disappeared, and the second alternative treatment is rendered as:

Take drye earth, \& stamp it small, \& sifte it, \& cast upon it, some wheat flower rank upon ranke, $\&$ then the yolke of egge $\&$ vinegar $\&$ mingle all togither. Then plaster or lute glasses, pottes or limbeckes $w^{\text {th }}$ it, \& drye them in the shadow, \& then will neuer fayle now breake in the fire. You may also mingle it $w^{t}$ oxe bloude in steed of water, it is al so good for that purpose. (MS Ferguson 7, fol. 20r)

In the same vein, the scribe is not interested in etymological matters and, subsequently, omits every reference to other languages. Thus, the original secret "To make an akinge tooth to fall out" reads:

Take wheate, and mixe it with the milke of the herbe called in latin Herba lactaria, in french Tintimaille: or herbe a laite, in English Spurge, that hath milke in it, in greekeTithymalos, which is an herbe well inoughe knowen, and thereof make as it were a paste or dowe, $w^{t}$ the wich you shal fill the hole of thetooth, and leaue it in a certaine tyme, and the toothe wyll fall out of it selfe. (Piemontese/ Warde 1563, 74)

However, in the manuscript the information is rendered as "Take wheat, $\&$ mix it $w^{t}$ the milk of spurge, $\&$ make therof a paste $\&$ fill ye holed toth therof $\&$ leaue it in a certaine tyme $\&$ the toth wyll fall out by it self" (MS Ferguson 7, fol. 13r). Similarly, the instruction "Take the herbe that is called Pentaphillon or Quinquefollium, in Englishe Cinkfoyle, and braye it with any grease: and lay it vpon the place and the naile will come againe incontinent" (Piemontese/ Warde 1562b, 40) is copied down as: "Take the hearb Cinkfoile $\&$ bray it w ${ }^{t}$ anye greace, $\&$ lay it vpon ye place" (MS Ferguson 7, fol. 17r). 
As the manuscript is intended for personal use, the creator of MS Ferguson 7 frequently employs abbreviations for common endings, such as -er in neuer, -ur in humour and your, -es as in violettes and -us as in maruelous. The reader also finds shortenings, such as $\mathrm{lb}$ for pound, superscript letters, as in $y^{e}$ for the, $y^{t}$ for that, oyer for other, $w^{t}$ for with, $\mathrm{w}^{\mathrm{c}}$ for which and the omission of nasals, which are marked with a bar on top of the preceding vowel, as in then, them and wound, among other words. All these abbreviations are widely used in the period (Dawson and Kennedy-Skipton 1966, 18-21), since this sort of adaptation is commonplace practice in manuscript writing.

Additionally, the scribe in MS Ferguson 7 continually adapts the spelling of the printed text to conform to his own taste. Thus, a secret "To make a carbuncle, $\&$ all other botches, apostumes, $\&$ plague sores to breake a present remedye $\&$ easie to make," which appears in the manuscript as:

Take baysalt well beaten into pouder and sifted, incorporate $w^{t}$ the yolk of an egg, and lay it vpon the carbuncle or sores, and be assured $\mathrm{y}^{\mathrm{t}}\left(\mathrm{w}^{\mathrm{t}} \mathrm{y}^{\mathrm{e}}\right.$ grace of god) it will draw to it self all the venym and poyson of $\mathrm{y}^{\mathrm{e}}$ plague or sore, so $\mathrm{y}^{\mathrm{t}}$ in short tyme he shalbe cured: A remedy often times proued. (MS Ferguson 7, fol. 7r)

does not corresponds to the original spelling in Warde's edition:

Take Bay salte well beaten into pouder and sifted, incorporate it wyth the yelke of an Egge, and laye it vpon the Carbumcle or soore, and be assured that (wyth the grace of God) it wyll drawe to it selfe all the venim and poyson of the plague or soore, so that in short tyme he shall be cured: A remedy often tymes proued. (1562a, 39)

While Warde (or his editor) uses capitals in several ingredients and important words, the scribe in MS Ferguson 7 does not. Likewise, Warde's edition includes a final silent $<$ e in words such as laye, drawe, egge and yelke and a preference for $\langle y>$ in several common words, such as wyll and wyth. In turn, the compiler of MS Ferguson 7 abbreviates that, with and the, abbreviations that do not appear in Warde's translation.

In this respect, the compiler of MSFerguson 7 also personalizes the vocabulary and sometimes uses a synonym instead of the original term. Similarly, in "Oyle of Bengewyne," the last cause clause is slightly different: the MS Ferguson 7 scribe prefers the connector as, where the original uses for and, following the tendency for simplification, deintie has been omitted in the former. Likewise, the 
reader will notice the differences in punctuation: MS Ferguson 7 makes use of fewer or no punctuation marks, as in this case:

Take Bengewine as much as you will, and lay it vnder a dungehill in a vyolle or glasse well stopped (so that it take no vente) by the space of fiftene or twentye dayes: Than strayne it, and kepe it in a vyole, for it is a singuler and deintie oyle. (Piemontese/ Warde 1562a, 51)

Take bengewine asmoch as you will and lay it vnder a dongehill in a viole or glasse well stopped (so $\mathrm{y}^{\mathrm{t}}$ it take no vent) by the space of 15 or 20 dayes, then streyn it and kepe it in a viole as a singuler oile. (MSFerguson 7, fol. 7v)

Finally, with very few exceptions, the scribe of MS Ferguson 7 omits comments which are not of a proper medical nature, such as "It is a secrete that Women commonly vse" (Piemontese/ Warde 1562b, 36), as well as the final efficacy phrase that is present to assure the reader of the validity of the remedy. When included, the scribe often prefers the Latin formulation, as in "et curabitur" (MS Ferguson 7, fol. 16v) instead of the original "and it shalbe cured" (Piemontese/ Warde 1562b, 35). The preference for Latin is patent in a title which in Warde's edition is in English "To make a woman beare Children" $(1563,8)$, but is in Latin in the manuscript: "Of mulier fiat puerpera" (MS Ferguson 7, fol. 9r), and in other formulas whereby "as before is sayde" (Piemontese/ Warde 1562b, 62) turns into "vt predictum" (MS Ferguson 7, fol. 19v). Whoever the creator of the handwritten copy was, the fact that he translated these parts into Latin indicates the learned character of the owner and likely his familiarity with the recipe genre, since the usual formulas used in recipes were wellknown to him.

\section{Conclusions}

The advent of the printing press hel ped popularize medical writings. Within that genre, books of secrets enjoyed such widespread circulation in sixteenth-century Europe that some, such as The Secrets of A lexis, were true bestsellers of the period. Thus, some readers even made their own handwritten copies intended for personal use. One of these handwritten versions, MS Ferguson 7, is kept in Glasgow University Library. From the examination of the manuscript several conclusions can be drawn. 
First, the title can be considered inaccurate, given that the handwritten copy includes only a small portion of the secrets contained in the well-known printed book. A mong the varied array of secrets included in the original The Secrets of A lexis, the scribe's main preferences were for medical remedies. The lack of interest in other topics included in the printed book, such as recipes to produce perfumes and soaps and to preserve food, which are completely absent in the handwritten collection, could indicate the compiler's sex. Theneeds and interests are more in line with those of an early modern man rather than with those of a woman from the period.

Similarly, the exploration of the content of MS Ferguson 7 suggests that the compilation is the result of a personalization of the contents. In the process of writing, the author of the manuscript did not simply duplicate the original source, but rather modified, summarized, and shaped the copy. He made a personal adaptation of the contents, the spelling and the linguistic formulation of the material.

In contrast to the printed text, which is usually considered to be invariable, handwritten recipe compilations are to be seen as dynamic artifacts that are personalized to suit the creator's needs. In this way, the manuscript becomes a flexible text, unlike its source. The printed text is susceptible to being altered according to the compiler's preferences in terms of content and linguistic formulation. This practice shows the vitality of manuscript culture at the time, as well as the interplay between the printed text and manuscript writing, whereby readers are not just scribes, but creators of new texts.

In the end, the printed text is the foundation and the necessary component for the entire compilation, even if the scribe voluntarily fails to acknowledge the modifications made. Here, the MS Ferguson 7 compiler is not a mere copyist but becomes a creator of a new text, given the plasticity and flexibility provided by the manuscript as opposed to the immutability of the printed text. This is an idea that needs further exploration in a different study. A nother matter which has not been resolved is who the compiler of MS Ferguson 7 was. Unfortunately, this is one of the many secrets that remain to be revealed in the future. 


\section{References}

Alonso-Almeida, Francisco. 2013. "Genre Conventions in English Recipes, 1600-1800." In Reading and Writing Recipe Books 1550-1800, edited by Michelle DiMeo and Sara Pennell, 68-92. Manchester: Manchester University Press.

Barbierato, Federico. 2011. "Writing, Reading, Writing: Scribal Culture and Magical Texts in Early Modern Venice." Italian Studies 66 (2): 263-76. doi: 10.1179/ 174861811X13009843386710.

Bela, Zbigniew. 1999. A lexego Pedemontaná táiemnice. Krakow: Wydawnictwo Medycyna Praktyczna.

Cruz-Cabanillas, Isabel de la. 2017. "Genre and Text-Type Conventions in Early Modern Women's Recipe Books." Revista de Lingüística y Lenguas A plicadas 12: 13-21.

Dawson, Giles E., and Laetitia Kennedy-Skipton. 1966. Elizabethan $\mathrm{H}$ andwriting 1500-1650: A Guide to the Reading of Documents and $\mathrm{M}$ anuscripts. London: Faber and Faber.

Dodoens, Rembert. 1578. A Nievve Herball, or Historie of Plantes: wherein is contayned the vvhole discourse and perfect description of all sortes of $\mathrm{H}$ erbes and Plantes: their diuers \& sundry kindes: their straunge Figures, Fashions, and Shapes: their $\mathrm{N}$ ames/ $\mathrm{N}$ atures/O perations/and $\mathrm{V}$ ertues: and that not onely of those whiche are here growyng in this our Countrie of Englande/but of all others also of forrayne Realmes commonly vsed in Physicke. London: by Mr. Gerard Dewes.

Eamon, William. 1984. "Arcana Disclosed: The Advent of Printing, the Books of Secrets Tradition and The Development of Experimental Science in the Sixteenth Century." H istory of Science 22 (2): 111-50.

Eamon, William. 1985. "Books of Secrets in Medieval and Early Modern Science." Sudhoff's A rchiv 69 (1): 26-49.

Eamon, William. 1994. Science and the Secrets of $\mathrm{N}$ ature. Princeton: Princeton University Press.

Eamon, William. 2011. "How to Read a Book of Secrets." In Secrets and Knowledge in M edicine and Science, 1500-1800, edited by Elaine Leong and Alisha Rankin, 23-46. Aldershot: Ashgate.

Eamon, William, and Francoise Paheau 1984. "The Accademia Segreta of Girolamo Ruscelli: A Sixteenth-Century Italian Scientific Society." I sis 75 (2): 327-42.

Ferguson, John. 1906. Bibliotheca Chemica: A catal ogue of the al chemical, chemical and pharmaceutical books in the collection of the late James Y oung of Kelly and D urris. Glasgow: James Maclehose and Sons. 
Ferguson, John. 1959. Bibliographical $\mathrm{N}$ otes on Histories of Invention and Books of Secrets. 2 vols. London: Holland Press.

Glasgow University Library. Catalogue of the Glasgow University Library. Accessed July 8, 2020.

http:/ / collections.gla.ac.uk/ \# details/ ecatalogue/ 265620.

Pennell, Sara, and Michelle DiMeo. 2013. "Introduction." In Reading and Writing Recipe Books 1550-1800, edited by Michelle DiMeo and Sara Pennell, 2-22. Manchester: Manchester University Press.

Petti, Anthony G. 1977. English Literary H ands from Chau cer to D ryden. London: Edward Arnold.

Piemontese, Alessio. 1562a. The Secretes of the Reuerende M ayster A lexis of Piemovnt. Containing excellent remedies against diuers disease, woundes, and other accidentes, with the maner to make distillations, parfumes, confitures, dyinges, colours, fusions, and meltinges. A worke well approued, very profitable and necessarie for euery man. $\mathrm{N}$ ew ely corrected and amended, and al so somew hat enlarged in certaine places, whiche wanted in the fyrst edition. Translated oute of Frenche into Englyshe, by William Warde. Translated by William Warde. London: Roland Hall for Nycholas England.

Piemontese, Alessio. 1562b. The thyrde and last parte of the Secretes of the reuerende $M$ aisster A lexis of $P$ iemont, by him collected out of diuers excellente A uthors, with a necessary Table in the en de, contayining all the matters treated of in this present worke. Englished by Wylliam Warde. Translated by William Warde. London: Roulande Hall for Nycholas England.

Piemontese, Alessio. 1563. The second parte of the Secretes of M aister Alexis of P iemont, by him collected out of diuers excellent auctheurs, and newly translated out of French into English, with a generall Table of all the matters conteyned in the sayde Booke. By W ylliam W ard. Translated by William Warde. London: Roland Hall for Nicholas Englande.

Piemontese, Alessio. 1565. Glasgow U niversity Library M S Ferguson 7.

Preston, Jean F., and Laetitia Yeandle. 1999. English H andwriting 1400-1650: A n Introductory M anual. North Carolina: Pegassus Press.

Rey-Bueno, Mar. 2005. "Primeras ediciones en castellano delos libros secretos deAlejo Piamontés." Pecia Complutense 2 (2): 26-34.

Saguar-García, Amaranta. 2012. "Una edición desconocida del Libro de los Secretos de Alejo Piamontés: Juan Perier, Salamanca, 1573." In El pasado ajeno. Estudios en honor y recuerdo de J aime M oll, edited by Guillermo Gómez Sánchez-Ferrer and Amaranta Saguar-García, 59-80. Córdoba: Academia de Cronistas de Ciudades de Andalucía.

Stijnman, Ad. 2012. "A Short-Title Bibliography of the Secreti by Alessio Piemontese." In TheA rtist's Process: Technol ogy and Interpretation, edited by 
Cruz-Cabanillas

Sigrid Eyb-Green, Joyce H. Townsend, Mark Clarke, Jilleen Nadolny and Stephanos Kroustallis, 32-47. London: A rchetype Publications.

How to cite this article:

Cruz-Cabanillas, Isabel de la. "The Secrets of A lexis in Glasgow University Library MS Ferguson 7." SEDERI 30 (2020): 29-46.

https:/ / doi.org/ 10.34136/ sederi.2020.2

A uthor's contact: isabel.cruz@uah.es

Postal address: Departamento de Filología Moderna - Universidad deA Icalá de Henares

- Colegio de San José de Caracciolos - Trinidad 3 - 28801 Alcalá de Henares (Madrid) - Spain

Submission: 07/ 11/ 2019

A cceptance: 13/ 02/ 2020 


\title{
Writing and weaving: The textual and the textile in Spenser's 1590 Faerie Queene, III. .*
}

\author{
Joan Curbet Soler \\ U niversitat A utònoma de Barcelona, Spain
}

\begin{abstract}
Most often, Ovidian allusions are woven into Edmund Spenser's The Faerie Queene (Books I-III, 1590) without developing into an open re-telling of myths. Onesignificant exception occurs in Book III, Canto 1: theretheaction comes to a temporary stop in order to make space for a detailed description of the tapestry in the hall of Castle Joyous, which depicts thestory of Venus and Adonis. This article intends to offer a reading of that episode that focuses on the importance of materiality and self-reflexivity as keys to its significance at the opening of Book III, and in the larger structure of The Faerie Q ueene.

Here, the descriptive powers of the poet are both foregrounded and questioned, in a double movement of ekphrasis which gestures towards a serious interrogation of the value of representation, both in poetry and the visual arts. Implicitly, it is the poet (and through him, the reader him/ herself) that must question his/ her role and participation in the gradual and often painful awareness of the body that is foregrounded throughout Book III.
\end{abstract}

KEYWORDS: Spenser; representation; "Arras" tapestries; ekphrasis; textuality; Britomart; body.

Escritura y tapiz:

Lo textual y lo textil en The Faerie Queenede Edmund Spenser, I.1 (1590)

RESUMEN: Muchas alusiones ovidianas se incluyen en The Faerie Queene (1590) de Edmund Spenser (Libros I-III), sin que ello implique una recreación completa de esos mitos. Una excepción muy significativa a esta regla sucede en el Libro III, Canto I: en ese momento la acción del

\section{Escrita e tecelagem: \\ 0 textual e o têxtil em The Faerie Queenede Spenser, III.1. (1590)**}

RESUMO: Texto São muitas as alusões ovidianas que Edmund Spenser entretece em The Faerie Q ueene (Livros I-III, 1590), sem que isso implique voltar a narrar esses mitos inteiros. Uma exceção significativa ocorre no Livro III, Canto 1: aí a ação é temporariamente suspensa para dar lu-

\footnotetext{
* This research article is part of the project "Towards a New Aesthetics of Elizabethan Poetry: Critical Reassessments and New Editions of Neglected Texts" (reference number FFI2017-82269-P, ENARGIA).
}

** Translation into Portuguese by Miguel Ramal hete. 
poema llega a detenerse por unos momentos, para así hacer una descripción detallada del tapiz del salón principal de Castle Joyous, que narra la historia de Venus y Adonis. El presenteartículo pretende ofrecer una lectura de ese episodio que se centre en la importancia de los conceptos de materialidad y autoconciencia como claves de su significado, al principio del libro III.

En este episodio, los poderes descriptivos del poeta quedan notablemente destacados, pero también cuestionados, en un doble movimiento de ekphrasis que apunta hacia una interrogación seria del propio valor de la representación, tanto en la poesía como en las artes visuales. Implícitamente, es el poeta (y a través de éste, el propio lector o lectora) quien debe cuestionar, al fin, su papel y su participación en la gradual y dolorosa conciencia del cuerpo que se desarrolla y se explora a lo largo de todo el libro III.

PALABRAS CLAVE: Spenser; representación; tapices de "Arras"; ekphrasis; textualidad; Britomart; cuerpo. gar a uma descrição detalhada da tapeçaria no salão de Castle Joyous, que descreve a história de Vénus e Adónis. Este artigo oferece uma leitura desse episódio centrada na importância da materialidade e da autoreflexividade como chaves para a sua relevância na abertura do Livro III e na estrutura mais vasta de The Faerie Quene.

Nesteepisódio, os poderes descritivos do poeta são simultaneamente postos em relevo e em questão, num duplo movimento de écfrase que aponta para uma interrogação séria sobre o valor da representação, tanto na poesia quanto nas artes visuais. Implicitamente, é o poeta (e, através dele, o próprio leitor ou a própria leitora) que deve questionar o seu papel e participação na consciência gradual e muitas vezes dolorosa do corpo que está em primeiro plano ao longo do Livro III.

PalavRas-Chave: Edmund Spenser; representação; tapeçarias de arrás; écfrase; textualidade; Britomart; corpo.

\section{Introduction}

On the walls of a magnificent inner room at Castle Joyous, several tapestries are hanging. The reader of Edmund Spenser's The Faerie Q ueen e has the opportunity of considering them in detail in Canto 1 of the third Book, in the 1590 edition of the epic; as the female knight Britomart is received into Malecasta's rooms along with Redcrosse, the poem noticeably slows its pace so as to offer a detailed description of these embroideries, which showcase a vivid retelling of the myth of Venus and Adonis. Spenser was of course familiar with tapestries such as these existing in actual reality, and many of the readers of the 1590 Faerie Q ueene were as well, especially those belonging to the upper circles of the aristocracy or to the immediate environment of the court. But the imagined hangings in the poem exert a peculiar fascination of their own, being "a work of rare deuice, and wondrous wit" (III.i.32.6). They call attention both to the short narrative they offer and to their own nature as objects of decoration and art, and this double function requires a particular attention and effort on the part 
of the reader/ viewer. An attention that the abundant secondary literature on the poem has not al ways dedicated to them, often being attracted to other, more polemical critical loci.

The aim of the present article is to return to that specific moment in the poem, to re-evaluate its significance within Book III and within the quest of the female knight, Britomart; beyond this, it attempts to assess its ekphrastic quality and the light that it sheds on Spenser's critical self-consciousness as a poet. I intend to show that this episode, because of the questions it poses (rather than the certitudes it may offer) is especially indicative of one aspect of Spenser's art of allusion and suggestion, allowing the reader not only to establish key thematic connections all across the fabric of the poem, but also leading him or her to consider the difficult position of the poet in his artistic endeavor. All this is done through a serious emphasis on the material quality both of the tapestries that are described and of the text within which they are embedded; both poem and visual art appear here as complex, physically articulated constructs that require a consideration of their involvement within each other, and of the author's role as the ultimate maker of both. It is necessary to proceed, however, from a brief consideration of previous critical discussions of this passage; it is only in this way that we will be able to weave our own path into the patterns of the poem.

\section{Earlier approaches}

While the ornaments in Malecasta's rooms have been examined several times in the complex alleyways of Spenserian criticism, some significant work remains to done. Let us discuss briefly the emphases of these discussions, before moving on and trying to complement them. In the classic The Allegory of Love, C.S.Lewis cannily described those tapestries as "a picture not of lust in action, but of lust suspended, lust turning into what now would be called skeptophilia"; the figures of Venus and Adonis were considered there not as related to Britomart's individual quest, but only in contrast to their later representation in the Gardens of Adonis (1936, 331-32). ${ }^{1}$ Only a few

\footnotetext{
${ }^{1}$ Immediately after his discussion of the Gardens of Adonis and of the Bower of Bliss, Lewis was quick to point out that "allegory is not a puzzle [...]. The worst thing that we can do is to read it with our eyes skinned for clues, as we read a detective story"
} 
years earlier (1930), Frederick Hard had explored a completely different approach, focusing also on the tapestries, but broadening the perspective so as to imagine Spenser's experience of similar works within aristocratic houses, and in the court itself; in this way, a solid connection was established between the fictional hangings and their role in actual reality as objects of luxury, even if no direct links were established with specific historical embroideries. In later studies concentrating on Britomart's adventures, such as the magisterial monograph by Thomas P. Roche on Books III and IV of The Faerie Q ueene (The Kindly Flame, 1964), the Venus/ Adonis tapestry was alluded to, but only in passing and connecting it to C.S. Lewis's earlier analysis, and thus relating the lascivious gaze of Venus on Adonis to that which Malecasta projects on Britomart: "Lust in the eyes is precisely the particular vice of Castle Joyous, and the tapestry of Venus and Adonis is its appropriate emblem [...]. The vice of skeptophilia is precisely what Spenser emphasizes in describing Malecasta" $(1964,68)$. At this particular point, thematic analysis still predominated over materialist readings, or over interpretations involving the history of decorative objects.

In the last decades of the twentieth century, other works of art and other tapestries in The Faerie Q ueene were commented on far more often than Malecasta's: the embroideries at the castle of Busirane, as well as his sadistic pageantries, naturally attracted more critical attention, in great part because they are more transparently involved with gender politics. Essential articles concentrating on Book III, such as the one published by Lauren Silberman in 1987, do not even mention the episode at Castle Joyous. An earlier article from the seventies, however, needs to be mentioned in this context: Claud A. Thompson's “Spenser's 'Many Faire Pourtraicts, and Many a Faire Feate'" (1972), which considers the visual arts and their various roles in the poem, paying special attention to therhetorical devices through which Spenser makes their descriptions so vivid, beyond their possible allegorical function. A major step in the same direction has been made more recently by Christopher Burlinson in his book-length study A llegory, Space and the $M$ aterial W orld in the W ritings of Edmund Spenser: a short but suggestive mention of the Castle Joyous episode

(1936), an observation that has been inspirational to much criticism on Spenser, and that I have also tried to take into account in this article. 
allows Burlinson to sidestep the question of poetic signification and to place it within a richer, wider context:

Paying attention to objects allows us to think historically about them, about how their stories areinscribed or effaced both within the poem and in the world from which the poem emerges. Such questions invite a partly historicized reading; looking at the literary passage describing the hangings against the physical contexts which informed gallery spaces in the sixteenth century, but also a reading that is sensitive to the poem's approach to objects and the difficulty it has (and flaunts) when describing them. (Burlinson 2007, 65)

Here we are far closer to cultural history than to a simple literary analysis. The consideration of the tapestries qua tapestries (which Burlinson proposes, but does not develop in relation to the Venus/ Adonis hangings) will allow us to think of them as objects, deeply embedded within The Faerie Q ueene, but also finding their place within the history of material goods in the Renaissance. ${ }^{2}$ The cultural role of such possessions responded to a variety of political, social and artistic intentions, and could be put to a wide number of uses. This suggests that it would be a mistake to oppose the allegorical or poetic content of the tapestries to their role as physical possessions; both aspects, in fact, are essential in the overall effect produced by the scene, and both are part of the game of signification elicited by it. However, there have been only occasional approaches to The Faerie Q ueene using this kind of methodology: a significant exception is a chapter by Rachel Eisendrath in her book Poetry in a W orld of Things: A esthetics and Empiricism in Renaissance Ekphrasis (2018), in which she identifies the ekphrastic patterns used by Spenser when presenting pictorial works in his poem, but without considering those in Malecasta's castle. Even though Eisendrath produces a major material and objectual reading of the art collection in the House of Busirane, she does not mention the hangings in Castle Joyous at any point. ${ }^{3}$ Much work on them, therefore, remains to be done.

\footnotetext{
${ }^{2}$ A tradition of analysis that was heralded by the influential study by Lisa Jardine, W orldly Goods (1996).

${ }^{3}$ One general point made by Eisendrath deserves special consideration: the idea that, when it comes to representations of visual arts inside the poem, The Faerie Queene "strives towards a completion of meaning at which it can never fully arrive [...]. The poem remains in a state of internal conflict and irresolution, calling for our ongoing involvement" (2018, 80, emphasis mine). The various responses that our specific stanzas (III.I.34-38) may elicit in the reader are also an essential aspect of the present article.
} 
This article will now proceed from a consideration of the material nature of the tapestries towards a discussion of their potential for signification, and of what this potential entails for the respective positions of the reader and the poet.

\section{The tapestry and/in the text}

As the Christian knights enter Castle Joyous, the attention of the reader (far more than that of Britomart or Redcrosse) is led towards the lavishly decorated walls:

The wals were round about apparelled

With costly cloths of Arras and of Toure,

In which with cunning hand was pourtrahed

The love of $V$ enus and her Paramoure

The faire A donis, turned to a flowre,

A work of rare deuice, and wondrous wit. (III.i.34.1-6)

From the beginning of the description, the notion of wonder is associated with the hangings. They are presented as "work of rare deuice and wondrous wit," both characteristics being related to the higher (rational) capacities of the soul: a "deuice" can only be created and appreciated with the help of the intellectus, the "wit" is indispensible in the organization of abstract thought and, of course, in the production both of art and of poetry. Penelope will also be presented by Spenser in the A moretti as having "deuiz'd" a "web" or tapestry thanks to her "subtile craft" (23), and the pen of an artist or of the poet will also be presented there as able to "deuize" the colors in his portrait of the beloved (17); in both poems, significantly, this artistic capacity is undercut by the weaver's will (23) or by the artist's own shortcomings (17), and in neither of them does the work lead to a full, satisfactory mimetic performance. The "wit" and the "deuice" that are so visibly present in the tapestry at Castle Joyous, however, have the function of conveying meanings or significant connotations to their viewers or their audience, even as their relation to the immediate action of the poem is far from immediately transparent. ${ }^{4}$

\footnotetext{
${ }^{4}$ And, in any case, it can never be fixed into a stable, fully unified message, as in the case of most medieval allegories. As Kenneth Gross has put it in relation to Spenserian iconography , "in every expansive progression towards a stablecenter, in every attempt to achieve something like visionary identification with a sacred emblem, the fear of fixation in subsequent misreadings haunts the literary quest like a demon" $(1985,17)$.
} 
In order to understand their function in this particular passage and in Book III at large, we will have to broaden our perspective.

The explicit reference to the "costly clothes of Arras and of Toure" in stanza 34.2 leads the reader's attention firmly towards the material quality of the hangings, and creates a specific set of expectations that frames the entire reading of the following stanzas. These lines appeal directly to cultural memory; in 1590, a number of the readers would have had direct experience of hangings similar to these, and the text seeks to access that part of their experience and to make it work to the benefit of the poem. In late sixteenth-century England, those who had not seen similar tapestries would have at least heard of them; the mention of "Arras" and "Toure" establishes a direct continuity between this precise moment in the poem and the culture of great English houses, where textile works imported from these foreign locations, or commissioned to them, had been prominent since the great revival of that art form under Henry VIII. The tapestries commissioned to Arras, or imported from there, were far more prestigious than those coming from Tours; they would be most vividly displayed in the diplomatic meetings where they performed a decorative role. According to the latest historical scholarship in this area, Queen Elizabeth did not buy many tapestries in her reign; she generally used the enormous collection that had been gathered by her father, which at the end of the century was still considered luxurious enough to be put on display repeatedly. Sometimes the doors of places holding the royal collection of tapestries, such as the Great Wardrobe Depot, were open for specific visitors, such as the lawyer Paul Hentzer:

Upon entering, we were obliged to leave our swords at the gate and deliver them tothe guard. When we were introduced, we were shown about ten large pieces of "A rras" belonging to the Crown, all made of gold, silver and silk; several saddles covered with velvet of different colours; an immense quantity of bed-furniture, some of them most richly ornamented with pearl [...]. (Rye 1865)

This description gives us an initial idea of the richness and variety of the tapestries, even when they were compared to thelavish and pearlornamented bed-furniture of the House of Tudor. But it was at Hampton Court that the tapestries were exhibited to their greatest effect. It was assumed that a number of them would decoratethe walls when diplomatic missions were received there, and that the Queen would surround herself with them, in order to produce a rich, 
brilliant, multi-colored space for the negotiations to take place. Modern historians have suggested that a group of three sets was left hanging all the year round in Hampton Court; these would correspond to the A braham, Tobias and Caesar pieces, three favorites of Henry VIII, which would remain an essential part of the Tudor court decorations until the early seventeenth century. ${ }^{5}$ In 1599 , Thomas Platter wrote about his own experience of these or similar tapestries in a guided visit to Hampton Court. There he was led to a large hall

[...] containing many fine royal beds, also numerous canopies and royal chairs all very lavish and ornate; and the walls everywhere were hung with extremely costly tapestries worked with gold, silver and silk, so life-like that one might take the people and plants for real. $(1937,201)$

This "life-like" quality is the most remembered characteristic of the tapestries, the one which recurs most often in contemporary descriptions of them. This almost illusionistic capacity was generated by the suggestion of the tinctures, including deep reds, blues and greens that were richly painted over the metallic threads of the embroideries, aiming to preserve their brilliance for centuries. It is precisely in theseterms that wehaveto think of Malecasta's tapestries: as richly ornamented textiles meant not only to dazzle and to impress, but to provoke in the viewer an impression of liveliness that, for the contemporary reader, would be unequalled by any other material goods of the period.

Once the connections to actual material tapestries have been established (a subject to which I will shortly return), the poem proceeds to the description of the myth itself. To what extent is its rendering of a visual narrativesuccessful? The answer to this question must depend on the degree to which the reader is willing to collaborate in the appreciation of the textual and poetic quality of these specific stanzas. Their emphasis is put on the active role of Venus as seducer, and on the passive position of A donis as seduced; the hunting scenes from Ovid are completely sidestepped, so that the erotic aspects of the narrative can be enhanced. In doing this, Spenser moves away from the cynegetic themes that were common to many real-life tapestries, and which had contributed so much to their dynamism and visual impact (for instance, in the lavish and

${ }^{5}$ This detail has been suggested by the art historian Thomas P. Campbell $(2007,352)$. 
spectacular H unts of M aximilian, produced in 1531-1533 in Brussels, in which the representation of the encounter with a boar plays a fundamental part). ${ }^{6}$ The natural environments that are described instead in stanza 35, however, are also among the favorite themes of the art of Arrras tapestries: the lush, flowery spaces in which Venus makes the garlands for his lover ("girlonds of each floure that grew, To crowne his golden locks with honour dew," III.1.35, 4-5), or the fountain where she bathes him away from the sight of mortals (" [...] or bathe him in a fountaine by some covert glade," III.1.35, 9). This allows the reader to think of scenes in which the predominant tinctures would be bright green and deep blue; at this point it is the reader him/ herself who is establishing theconnection between words and images, since the situations are enumerated rather than described. The expectations that have been generated by alluding earlier to the Arras/ Tours tapestries work here to provide the cultural memory on which the poet is counting, so that these scenes can be imagined by the reader in visual terms as the lines enumerate them.

In stanza 36, the visual and sensual quality of the description takes a clear precedence over the simple narration of events. The mantle of Venus is spread over Adonis, "colour'd like starry skies," while her arm is set "underneath his hed" (III.i.36, 1-3); here her gesture and bodily attitude are captured in movement as she covers him, and the colors of her clothes reproduce a clear nocturnal sky, thus evoking, over the surface of thetapestry, an interplay between golden and deep blue tinctures (stars and sky). The visual description is here carefully framed in lines that, at the same time, call our attention to their own verbal nature; with the help of anaphora and of alliteration, the reader is led to appreciate the linguistic quality of the text even as the description of the images proceeds:

And with ambrosiall kisses bathe hereyes;

And whilest he bath'd, with her two crafty spyes,

She secretly would would search each daintie lim,

And throw into the well sweet Rosemaryes. (III.i.36, 4-7)

The text is here as ornamented, through purely linguistic means, as the textile surface that is described, verbal virtuosity mirroring the tinctured decoration of an Arras tapestry. The anaphorical and

\footnotetext{
${ }^{6}$ It is in the tapestry dedicated to the month of December where the hunting of a wild boar features more prominently. The series $H$ unts of $M$ aximilian was designed Barend van Orley. http:/ / cartelfr.louvre.fr/ cartelfr/ visite?srv=car_not\&idN otice=14769.
} 
alliterative nature of these lines appeals to the ear of the reader as much as the imaginary tapestries would appeal to the eye of its viewers. ${ }^{7}$

The removal of Adonis' encounter with the boar from this version allows it to sidestep, to a large extent, the conventional Christian discourse on the story, and diminishes its doctrinal or moral content; by the same token, it enhances the more decorative and sensual quality of the text/ tapestry. The Spenserian rendering of the Ovidian myth concentrates first on the erotic play between thelovers, in which Venus takes the active part, and secondly on the bloodshed of Adonis's body and the lamentation of Venus, which finally leads to her regenerating act of life-giving, turning his gory remains into a living plant, one that seems to livesimultaneously on the tapestry and on the page. The removal of the boar from the scene certainly responds to an iconographic tradition that was developing and asserting itself firmly throughout Europe. In the second half of the sixteenth century, the versions painted by Titian or by Paolo Veronese dwelt on different moments of the erotic attraction between Venus and Adonis, leaving aside the more violent aspects of the hunting scene. Veronese's 1580 version foregrounded an entirely relaxed contact between lovers, with Adonis profoundly asleep in Venus's lap, even as Cupid covered one of his dogs with a mantle, indicating an underlying tension in the scene which would only emerge later, but was not visible in the painting itself. ${ }^{8}$ Earlier approaches by Titian (from the decade of 1550) showed a far more conflicted situation with Adonis abandoning a pleading Venus, already on his way to his death. Titian's renderings of the story, and of that particular moment in it, showcased the fact that it was not necessary to actually represent the boar in order to explore its larger connotations: it was presented, therefore, as an erotic encounter prefacing a tragic ending. His last approach to the myth (1554) can be read as a delicate prolepsis, showing the movement of the boy away from the protection and love of Venus and towards the teeth of mortal, physical reality. The gesture

\footnotetext{
${ }^{7}$ This particular solution of the pictura/ poesis debates seems to follow very much al ong the lines of the indications given by Leonardo da Vinci in his notebooks on the subject, especially in what concerns the respective forms of sensorial reception by readers and by viewers (Da Vinci 1970, I, 57).

${ }^{8}$ Veronese's oil painting is in the Museo del Prado, and can be seen through the museum website: https:/ / www.museodel prado.es/ coleccion/ obra-de-arte/ venus-yadonis/ 692667da-d0f5-4765-ba03-30fdce3513d1.
} 
of Adonis wrestling himself from the arms of Venus was, without a doubt, the most original element of Titian's version; the moment of death was thus removed from the scene but el egantly suggested, with Cupid left sleeping in the background, unable to protect the couple. ${ }^{9}$ It can be asserted, then, that the removal of the boar from Spenser's approach to the myth in III.i (and, as a consequence, its relocation in a cage in thelater description of the Gardens of A donis) was a conscious and measured artistic option, which inserts itself in a specific tradition of visual renderings of the story. Considered exclusively as art objects, Malecasta's tapestries show interesting connections to the European iconographic tradition.

The last line of stanza 38 proves to be the one that poses the most questions, both in relation to the stanza it belongs to and in relation to Spenser's version of the myth ("Him to a dainty floure she did transmew| Which in that cloth was wrought, as if it liuely grew," III.i. $38,8-9)$. The leaves of the anemone seem to come out of the tapestry as if they were alive; there are no further indications about this movement other than the reference to their lifelikeness, so we must assume that this is the impression they have given to the knights who see them as they head towards the inner rooms of Castle Joyous. This is the impression they give, as well, to the reader who has followed the description of the myth through the last five stanzas. The projection of his/ her gaze meets the flower at the point at which it stands out from the entire work (or rather, works: textile and textual) it belongs to. Its organic quality has been given to it by the artists within its fictional world, but theultimateresponsibility for it lies with the poet. Does that near-miraculous presence confirm and complete the potent, bodily, sensual quality of the entire representation they belong to? And, if it does, does that naturalistic quality detract from the allegorical or moral potential of that representation?

The question can certainly be put in more general terms, before we return to stanza 38. Indeed, how can art (here, both visual and verbal) avoid becoming an enticement to physical desire if it inevitably depends on the figuring forth of vivid images, and if it is rendered in spectacular and lavish forms? At no point in the poem can we forget the deeply iconoclastic ideology rooted in late sixteenth-

${ }^{9}$ Titian's painting is to befound in the Museo del Prado, and is availableonlinethrough the museum website url: https:/ / www.museodel prado.es/ coleccion/ obra-dearte/ venus-y-adonis/ 692667da-d0f5-4765-ba03-30fdce3513d1. 
century Protestantism, which saw the use of images as dangerous in itself, and as responding to deep tendencies in the human soul. If this applies to religious discourse or to forms of spiritual teaching (as the writings of John Jewel, Richard Hooker and many others repeatedly asserted), the situation is even more dangerous in the case of secular writings or works of art. As Rufus Wood put it in his study of metaphorical language in The Faerie Q ueene, "the allegorist always faces either a representational compromise, or the risk of contaminating the work's own metaphors" (1997, 140); in late sixteenth-century culture there is always an underlying risk of "contamination" or lack of purity in the use of complex images with didactic purposes. And yet, in the particular stanzas we are examining, these dangers are not only suggested, but actively assumed and integrated in the act of representation. Spenser chooses to confront head on the moral dangers of artistic mimesis. The erotic potency of stanzas 35 and 36 prevents, as we have seen, their being received only in abstract or didactic terms: the reader must integrate that sensuality on his or her act of reading, as an essential part of his or her enjoyment of the lines. Whatever moral content the text might communicate, it certainly cannot come at the cost of forsaking its sensual pleasures, which here are foregrounded rather than eluded.

The whole stanza in which Adonis's transformation occurs (38) requires the full implication of the reader and cannot work adequately without it. The active wiping away of the blood from his body is represented as a constant movement of Venus's soft garment over his snowy skin, stained with his own gore; the alliterative play on sibilants recovers and renews the sensuality of stanza 36, until the moment of the transformation comes. It is therefore even more significant that this metamorphosis should not be directly described, but only mentioned: "Him to a dainty floure she did transmew, Which in that cloth was wrought, as if it lively grew" (III.i.38, 8-9, emphasis mine). The life-like quality of the anemones culminates the whole process of description (on the part of the poet) and observation (on the part of the reader), but the actual "transmewing" is not expanded on. The abundant blood, the white corpse, the movements of Venus are the elements described; what is it, then, that produces the powerful liveliness of the anemone? It is precisely the capacity of the reader him/ herself to imagine that plant "in the cl oth," designed in the A rras tapestry and having become al most alive in it. 
The emphasis on the textile nature of the scene ("which in that cloth was wrought") insists pointedly on the fact that the whole experience we are recreating as readers is a transference, a translatio, between the textile and the verbal. The final line brings us back firmly to the material, objectual nature of the hangings, and reminds us that the whole description has occurred under the sign of ekphrasis, the description of an art object in verbal terms. ${ }^{10}$ More specifically, the poet has gone as far as to develop a form of notional ekphrasis, developed over an imagined artwork. ${ }^{11}$ The sensuality of the description has ensured the reader's involvement in the imaginative construction of the tapestry; at its end, the cultural memories and expectations invoked at the beginning of the sequence are firmly recovered, and it is precisely on them that the culmination of the episode depends. An "Arras" tapestry would have involved only the finest materials, metallic threads that would have been carefully colored, and periodically cleaned and polished to ensure their quality; their dazzling nature and brightness would have been their most evident and memorable characteristics. Spenser does not need to describe the anemone in full: the colorful nature of the final scene, along with the final reminder that this is all rendered in Arras-like quality, and with the colors (red, white, green) belonging to that level of artistic execution, ensures that the reader's memories of actual tapestries (directly seen, or at least heard about) will allow the anemone to appear in his or her imagination.

The poet has enlisted the imagination of the reader in order to project living images in the mind of the latter. Commenting on the various uses of ekphrasis in D on Quijote, E. C. Riley has made the point that it is not necessary for the reader to directly remember a specific visual work, or to have direct knowledge of it, for the effect to take place. "A piece of verbal discourse (and initially nothing else) has evoked an image in the mind of individual readers [...]. These visual

\footnotetext{
${ }^{10}$ The original use of the term in Hellenistic rhetoric was, according to Murray Krieger, "completely unrestricted: it referred, most broadly, to the description of something, al most anything, in life or in art" $(1992,7)$. It was only gradually that it came to define the description of an artistic object, with the description of the shield of Achilles in the Iliad as its main reference.

${ }^{11}$ The concept of a "notional" ekphrasis, as applied to fictional (non-existent) artworks, was originally introduced by Hollander (1988, 209), and was later developed by Heffernan (1993, 7). In an article centered on The Rape of Lucrece, Catherine Belsey has usefully offered a revision of scholarship on that theoretical matter $(2012,175-98)$.
} 
recognitions are capable of triggering a response of recognition from people who only know theoriginal by allusion or hearsay" $(1988,108)$. A similar effect would have been achieved by Spenser in readers who had not directly seen any real Arras tapestries, but knew them through verbal descriptions, of through their fame and prestige. Those few who had had a real experience of them would have been able to make the imaginary transition even more fluidly.

This particular use of notional ekphrasis, involving as it does the cultural memory of the reader and his/ her knowledge of artistic objects, inevitably calls our attention to the very fabric of the poem (textual, not textile) and to its own nature as an object of delicacy and virtuosic art. The poem is no less finely woven, no less rich in textures, than the Arras tapestry it includes within itself. Ultimately, its narrative role as a proem to Britomart's quest reminds us that the poet is the author of both: the tapestry has allowed him to introduce key topics (seduction, bloody sacrifice, creation, life-giving) that are essential to the plot involving the female hero and her evolution. The gore that covers Adonis's body and Venus' clothes is not only the result of the boy's ambition as a hunter; it is not only the boar that has shed it, but also the author himself, in his verbal imitation of textile matter, and it will be shed again in Britomart's quest, in moments that will remind us of Malecasta's tapestries. And the first of these moments will come very soon, as Britomart tries to leave the castle after the public discovery of her real gender identity, and is slightly wounded by the arrow of the faery knight Gardante ("he who looks," in IIII.i. 65). Despite her virtue and bravery, she is not yet able to protect herself completely against the onset of an external and treacherous desire. ${ }^{12}$

The conclusion of the sequence of tapestries, then, is the starting point for Britomart's dangerous search for her bodily integrity and chaste fulfilment, but it also inaugurates a narrative in which the very body of the poem will be questioned from within, in an interrogation of the author's ambiguous role as creator of vivid images in the mind (intellectus) of the reader. As Ernest Gilman once put it, Spenser, working as "an artist self-divided [...], may thus be said to internalize

${ }^{12}$ As Thomas P. Roche Jr. once put it, "perhaps Spenser is telling us that Britomart has partially succumbed to the beauty of Castle Joyous and thus deserves this slight wound [...]. The power of beauty to draw the eyes is the basis of both lewd and chaste love" (1964, 70-71). 
and, if uneasily, to accommodate the adversary postures of his age" (1986, 82). The ekphrastic quality of the entrance to Castle Joyous is in the end brought to bear on the poet himself and on his conflicted, difficult relationship to his verbal art.

\section{Projections and continuities}

The tapestries in Castle Joyous have acted both as proem and as prolepsis: they have given a ceremonial start to Britomart's adventures and to the main themes explored in them, not only in Canto I of Book III, but through the whole of her quest. On the part of the poet, insofar as he has attempted to become the creator of living images, insofar as he has attempted to breathe into his verbal tapestries the breath of life, he has implicitly established a parallel between himself and other powers, often demonic, in the textual fabric of The Faerie Q ueene. The resonances of this moment are echoed in several parts of the poem, both in the 1590 and 1595 parts, but I will restrict my examples to two moments also occurring in Britomart's quest.

The first of these moments occurs after the sinister procession, or pageant, created by Busirane in order to dramatize his fixation for Amoret in III.xii; there a series of characters masquerade so as to allegorize the diverse powers and capacities activated by personal love (hope, desire, doubt, fear, etc, often grouped in pairs). Allegory seems to run rampant here, representing a series of conventional poetic situations in terms that are sometimes formally coherent, and sometimes less so. In any case, the complex staging that Busirane creates requires a spectator, and does not get one but two: Britomart, the witness to theartistic scene, organized as a series of living pictures, and the reader him/ herself, observing it from the safety of the act of reading, deciphering it on the printed page. We find ourselves, once more, in the domain of notional ekphrasis.

Busirane is not only a wizard, but also a poet and an artist; the procession of living tableaux that includes and integrates the body of A moret is the work of a creative mind, one that is deeply steeped in the Petrarchan discourses of love and in the religio amoris (cultural fields that Spenser himself had mastered so well). When the imprisoned and bound A moret appears in the pageant, her breast is opened, her blood flows and her heart is ripped out, in a literal rendering of the allegorical tradition which puts the heart of the 
beloved at its core (III.xii.21). But the most shocking image in this sequence comes after the procession itself, when we find Busirane dipping his pen in the open breast of Amoret, so as to write with her blood:

[...] And her small wast girt round with yron bands, Unto a brazen pillour, by the which she stands.

And her before the vile Enchaunter sate,

Figuring strange characters of his art,

With liuing blood he those characters wrate,

Dreadfully dropping from her dying hart,

Seeming transfixed with a cruel dart. (III.xii.30, 8-9; 31, 1-5)

The visual, almost dramatic nature of this description, with Amoret tied to the pillar and her tormentor dipping his pen in her breast as he sits before her, both evokes and completes the sadistic pageant she has been a part of: it acts, in fact, as its culminating tableau vivant. ${ }^{13}$ Both Britomart and the reader witness the scene, and its ekphrastic nature is mediated by the presence of the heroine, who pays close attention, distancing herself from the situation even as she prepares to interrupt it. ${ }^{14}$ Britomart is not as innocent as she was in III.i. At this point she cannot become a passive object of desire, nor can she become a mere witness to the blood-shedding that male desire may bring about; she is now able to keep herself away from the dangers of a predatory seduction, and also to free others from it. Only to a certain extent, however: when taking the dart from Busirane's hands, she is also wounded by it and her blood once again falls on her white skin, thus repeating, on a smaller scale, the "goring" inflicted on occurred in Adonis's body in III.i:

From her (i.e. Amoret), to whom his fury first he ment, The wicked weapon rashly she did wrest,

And turning to her selfe his fell intent,

Unwares it strooke into her snowie chest,

That little drops empurpled her faire brest. (III. Xii. 33, 1-5)

\footnotetext{
${ }^{13}$ Harry Berger Jr. notes, in a similar vein, that "one is tempted to read the previous masque as an explication of what is happening here-or, conversely, to read this scene as the dramatic situation, previously unarticulated, which anchors the masque in the story of Britomart, A moret, and Scudamour" (1988, 184).

${ }^{14} \mathrm{~A}$ s Lauren Sil lberman has cleverly pointed out, in theH ouse of Busirane Britomart has become "the reader's surrogate as an onlooker" $(1995,67)$.
} 
Britomart's wound has been "nothing deep imprest" (line 7), as the poet quickly specifies, and the wizard has cut her "unwares," as his attack was meant for A moret. But still "littledrops" of her blood have fallen once more, as they did at the end of Canto III. i. The wounds in A moret's breast will be closed as soon as Britomart rescues her from the wizardry of Busirane, yet the traumatic episode has al ready taken place, to a different degree, for both women: their blood has been shed in a terrifying staging of artistic fantasies, which have brought pictorial images to a semblance of life. If the third Book of The Faerie Q ueene is, as Harry Berger Jr. once put it, an exploration of "one-sided and premature union, development or fulfillment which must be obstructed or destroyed so that they may be repeated in more adequate form at a later, more appropriate phase" $(1988,117)$, then it must be added that both the beginning and ending of this exploration are marked by ekphrastic moments (in Cantos i and xii, with bleeding bodies at their respective centers) that involve a dangerous yet unavoidable bloodletting. The process of individuation and growth into chaste sexuality that Britomart has undertaken cannot take place, cannot be fulfilled, without these steps that make her painfully aware of her body, of its nature and of its limitations.

This physical and figural "goring" projects itself even beyond Book III, and reaches its culminating moment in Britomart's quest, her encounter with Radigund and her rescue of Artegall (V.vii. 29-34). If all of Britomart's progression has been defined by her desire to givea body to her original vision of Artegall in the magic mirror, her definitive encounter with him is preceded by a battle in which her identity as a female warrior has to be finally certified, in opposition to theunruly and matriarchal power of the A mazon: a fight between two models of femininity in which only one can remain. The encounter between them begins in traditionally Arthurian fashion, with each of them running against the other in full determination, until they begin to use their swords in order to mutilate the other's "dainty parts, created| for other uses than they then translated" (V.vii.29,8). This is a battle to the death in which the concept of femininity itself is at risk: it is only logical that blood, associated with female biology and with the act of birth giving, should flow abundantly in terms that take us back once more to the tapestry in Canto I. The women warriors cut each other's body deeply, so that their corporal fluids and entrails issue abundantly from their wounds (just like Adonis's blood fell out of his in III.i.38) and fall over the verdant ground, where they bathe 
the green grass, rendering it unrecognizable: from a site of life and fertility, it seems to be transformed into a space where only death is possible. Only the beheading of Radigund at the hands of Britomart, when she "both head and helmet cleft" (V.vii. 34,6) reverses this situation. ${ }^{15}$ Britomart has been "engor' $d$ " with her own blood, but this blood is also what allows her to free Artegall and to become united to him, in a marriage that will be abundantly blessed with royal offspring.

The use of red, white and green that was so prominent in Malecasta's tapestries is put to spectacular use in the final battle of Radigund versus Britomart. That connection in brilliant colors and in the theme of bloodletting can only become significant if the reader him or herself is willing to weave and unweave the poem as he or she is reading it, even if this reading takes place in different moments over time. Such a movement back and forth, in which colors and themes are constantly recovered, evoked or alluded to, that makes us move forwards even as we are looking backwards, is the most adequate image for almost any reading of The Faerie Q ueene. Because these thematic links have been established through two moments of strong notional ekphrasis (III.i.34-38, and III.xii.30-34), projecting themselves afterwards towards a third moment in the narrative (V.vii. 29-34), it is fully legitimate to ask ourselves about the significance of the relationship between visual arts and poetry in Book III. These two ekphrastic moments, with both reader and characters witnessing artistic pieces which involve a serious, material blood-shedding, suggest connections between the faerie weavers, wizards like Busirane and, inevitably, the author himself, who is weaving the largest pattern of all in his poem. If anything, these moments certainly point towards the strong self-consciousness of the poet, who is fully aware that his work, enmeshed as it is between the textual/ textural and the representation of vivid bodily forms, necessarily runs the risk of spilling over from the merely artistic into the magic, the pagan or the daemonic (the creation of the false Florimell in IIII.viii. 5-8, if it is taken as yet another moment of artistic self-reflection on the part of the poet, would only seem to confirm this). The insistence on the fully material quality of the works of art recreated in the poem implies also, in the end, an insistence on the verbal materiality of the poem itself,

${ }^{15}$ The role of Radigund as a counter-image of Britomart and her further function as a wider cultural signifier in Book V has been discussed in Curbet (2001, 157-72). 
in which words, the very matter of language, are also being used by the poet to create a semblance of life. ${ }^{16}$

In the various processes of blood-shedding that occur in the moments we have examined, neither the author not the reader are completely innocent. Both haveto participate of the bodying forth that occurs in the text at different levels and in different roles, just as the weavers of Malecasta's tapestries require an admiring audience for the gory sacrifice that they havelavishly woven. In order for the work of art to achievea full life-likequality (and, at thelevel of plot, in order for the female body itself to become both fertile and chaste) some blood needs to be shed, whether it is physical or figural, and the audience has to collaborate in its shedding. Like the hanging tapestries in Castle Joyous, the whole of The Faerie Queene stands precisely at the difficult point in which artistic representation attempts to becomelife-like, but also shows a full consciousness of the strong moral dangers involved in this attempt.

\section{Conclusion}

This article does not intend to suggest that the function of notional ekphrasis in Book III is to generate an "endless worke" of interpretation, as Jonathan Goldberg famously stated in reference to the whole of the poem, or as he has continued to affirm in more recent years (1981, 2009). ${ }^{17}$ Rather, my intention has been to show that the narratives embedded within the romance in the form of rich works of art, and witnessed by its fictional characters, draw strong attention to their own physical, material nature, and that by doing this they point to the materiality both of the poem and of the characters that inhabit

\footnotetext{
${ }^{16}$ According to Rachel Eisendrath, the whole poem thrives on contradictions of this kind: "The poem would die of success if it ever overcame its own contradictions; The Faerie Q ueene would at last become the letter to Raleigh. Happily, this is not what has happened. The poem remains in a state of internal conflict and irresolution, calling for our ongoing involvement" (2018, 80-81).

${ }^{17}$ It is worth remembering the entire sentence: "The writerly text is an 'endlesse worke' of substitution, sequences of names in place of other names, structures of differences, deferred identities. It plays upon a void: it occupies the place of loss, where Britomart's wound is extended to Amoret, where Amoret is 'perfect hole'" (Goldberg 1981, 12). Goldberg thus refers to an absolute sense of openness in the text; without going quite so far, I hope to have traced some spaces of fertile and productive ambiguity in my discussion of the tapestries both as objects and signifiers in Book III.i.
} 
it. Seduction and blood-shedding are the main subjects of the tapestries featuring Venus and Adonis in Castle Joyous; they are rendered there in such a spectacular display of craftsmanship that they not only imitate life, but tend to make it occur on their surfaces and especially, as we have seen, in the mind of their spectator/ reader. Seduction and blood-shedding, indeed, are also main topics in Britomart's quest, and they must be not only metaphorically assimilated but physically experienced by her, in a projection of artistic theme towards bodily and personal experience. The textual and the textile, as represented in Book III.i, establish a firm movement towards a greater, more complex awareness of the bodily.

The thematic components of the Venus/ Adonis tapestries are projected all through Book III, while their capacity to produce an imitation of life acts as a mirror both of the poet's artistic virtuosity and of the serious moral dangers it entails. Is it possible to create a near-perfect imitation of life without a sacrifice of blood, bodily or figural? Is it possible to represent life, or even to generate it (and this specific word applies both to Spenser and to Britomart) without losing a part, no matter how small, of one's own virtue or integrity? Finally, is it possible for the reader to distance her or himself completely from the sensual quality of art, visual or verbal, and to escape the inevitable spiritual or moral danger that it entails? The answer to these three questions in the poem rather veers, as I hope to have proved, towards the negative, but this does not detract from our need to rephrase them again and again as we read Book III and the rest of Britomart's adventures. The fact that The F aerie Q ueene should confront its limits in such a serious and sophisticated way is not necessarily a proof of the author's doubts about his poetic ambition; what it rather indicates is his awareness of its inevitable moral pitfalls, and of his need to confront them not from the safety of a doctrinal position, but from within the verbal matter of the poem itself.

\section{References}

Belsey, Catherine. 2012. “Invocation of the Visual Image: Ekphrasis in Lucrece and beyond." Shakespeare Q uarterly 63 (2): 175-98.

Berger, Harry, Jr. 1988. Revisionary Play: Studies in the Spenserian Dynamics. Berkeley: University of California Press.

Burlinson, Christopher. 2007. Allegory, Space and the M aterial World in the W ritings of Edmund Spenser. Cambridge: Boydell \& Brewer. 
Campbell, Thomas P. 2007. Henry V III and the A rt of M ajesty: Tapestries at the Tudor Court. New Haven: Yale University Press.

Curbet, Joan. 2001. "Repressing the Amazon: Cross-Dressing and Militarism in The Faerie Q ueene." In D ressing U p for W ar: Transformations of Gender and Genre in the Discourse and Literature of War, edited by Andrew Monnickendam and A ránzazu Usandizaga, 157-72. Leiden: Rodopi.

Da Vinci, Leonardo. 1970. The Literary W orks of Leonardo da V inci. Edited by Jean-Paul Richter. London and New York: Phaidon Press.

Eisendrath, Rachel. 2018. Poetry in a W orld of Things. A esthetics and Empiricism in Renaissance Ekphrasis. Chicago and London: University of Chicago Press.

Gilman, Ernest B. 1986. Iconoclasm and Poetry in the English R eformation: D own W ent D agon. Chicago: University Chicago Press.

Goldberg, Jonathan. 1981. Endlesse Worke. Spenser and the Structures of D iscourse. Baltimore: Johns Hopkins University Press.

Goldberg, Jonathan. 2009. The Seeds of Things: Theorizing Sexuality and $M$ ateriality in Renaissance Representations. New York: Fordham University Press.

Gross, Kenneth. 1985. Spenserian P oetics: Idolatry, I conoclasm and M agic. Ithaca: Cornell University Press.

Hard, Frederick. 1930. "Spenser's 'Clothes of Arras and of Toure'." Studies in Philology 27: 162-85.

Heffernan, James A.W. 1993. M useum of W ords. The Poetics of Ekphrasis from $\mathrm{H}$ omer to A shbery. Chicago: The University of Chicago Press.

Hollander, John, 1988. “The Poetics of Ekphrasis." W ord and Image 4: 209-19.

Jardine, Lisa. 1996. W orldly Goods. London: Macmillan.

Krieger, Murray. 1992. Ekphrasis: Thelllusion of theN atural Sign. Bal timore: The Johns Hopkins University Press.

Lewis, C. S. 1936. The Allegory of Love. Oxford: Oxford University Press.

Platter, Thomas. 1937. Thomas Platter's Travels in England. Edited and translated by Charles Williams. London: Jonathan Cape.

Riley, E. C. 1988. “Don Quixote: From Text to Icon.” Bulletin of the Spanish Society of A merica 8: 103-15.

Roche, Thomas P., Jr. 1964. The Kindly Flame: A Study of the Third and Fourth B ooks of Spenser's "Faerie Q ueene." Princeton: Princeton University Press.

Rye, William B. 1865. England as Seen by Foreigners in the Realms of Elizabeth I and James I. London: Russell Smith. 
Silberman, Lauren. 1986. “Singing Unsung Heroines: Androgynous Discourse in Book 3 of The F aerie Q ueene." In R ewriting the R enaissance: The Discourse of Sexual Difference in Early Modern Europe, edited by Margaret W. Ferguson, Maureen Quilligan, and Nancy J. Vickers, 267-71. Chicago: University of Chicago Press.

Spenser, Edmund. 1997. A moretti and Epithalamion: A Critical Edition. Edited by Kenneth J. Larsen. Tempe, A rizona: SUNY Press.

Spenser, Edmund. (1590, 1596) 2007. The Faerie Queene. Edited by A. C. Hamilton, Hiroshi Yamashita, Toshiyuki Suzuki, and Shohachi Fukuda. London: Pearson Education.

Thompson, Claud A. 1972. "Spenser's ‘Many Faire Pourtraicts, and Many a Faire Feate'." Studies in English Literature, 1500-1900 12: 21-32.

Wood, Rufus. 1997. Metaphor and Belief in The Faerie Queene. London: Macmillan.

H ow to cite this article:

Curbet Soler, Joan. "Writing and Weaving: The Textual and the Textilein Spenser's 1590 Faerie Q ueene, III.i." SEDERI 30 (2020): 47-68.

https:/ / doi.org/ 10.34136/ sederi.2020.3

A uthor's contact: Joan.Curbet@uab.cat

Postal address: Dept. Filologia Anglesa i de Germanística - Universitat Autònoma de Barcelona - 08193 Bellaterra (Cerdanyola del Vallès) Barcelona - Spain 


\title{
Representing creation, experiencing the sublime: The Longinian tradition in Tasso and Milton
}

\author{
Irene Montori \\ Sapienza U niversità di Roma, Italy
}

\begin{abstract}
This essay aims to demonstrate how Tasso and Milton were conscious of the Longinian tradition and aware of fashioning a poetry of the sublime when rewriting the story of creation. The author of II mondo creato incorporates the Longinian model of sublime ekstasis into his concept of meraviglia to construct his own poetics of artistic creation. Despite Milton's indebtedness to Tasso, in Paradise Lost the English poet distances himself from a full commitment to Longinian ekstasis and locates the sublime in a more dialogical, if not dialectical, compositional model of poetic creation. From a broader perspective, this paper aims to illustrate the centrality of the sublime in fashioning early modern literary poetics.
\end{abstract}

KEYWORDS: Tasso; Milton; creation; wonder; the sublime.

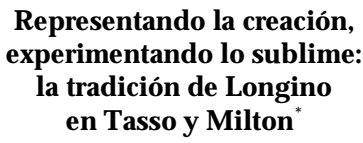

RESUMEN : Este artículo pretende demostrar cómo Tasso y Milton eran conscientes dela tradición longiniana y a la vez de estar creando una poesía de lo sublimeal reescribir la historia de la creación. El autor de II mondo creato incorpora el modelo longiniano del ekstasis sublime a su concepto de meraviglia para construir su propia poética de creación artística. A pesar de la deuda de Milton para con Tasso, en Paradise Lost el poeta inglés se distancia de un compromiso total con el ekstasis longiniano y ubica lo sublime en un modelo composicional más dialógico, si no dialéctico, de creación poética. Desde una perspectiva más amplia, este artículo intenta ilustrar la centralidad de

\section{Representar a criação, experienciar o sublime: A tradição Longiniana em Tasso e Milton ${ }^{* *}$}

RESUMO: Este artigo visa demonstrar como Tasso e Milton estavam autoconscientes da tradição longiniana e cientes de desenvolverem uma poesia do sublime ao reescreverem a história da criação. O autor dell mondo creato incorpora o modelo longiniano de ekstasis sublime no seu conceito de meraviglia para construir a sua própria poética da criação artística. A pesar da dívida de Milton para com Tasso, em Paradise L ost o poeta inglês afasta-se de um compromisso total com a ekstasis Ionginiana e localiza o sublime num modelo composicional mais dialógico, se não mesmo dialético, da criação poética. Em termos mais amplos, este artigo procura ilustrar a centralidade do

*Translation into Spanish by Tamara Pérez-Fernández.

** Translation into Portuguese by Miguel Ramalhete.

$$
\text { (C) ederi } 30 \text { (2020): 69-89 }
$$

https:/ / doi.org/ 10.34136/ sederi.2020.4 
lo sublime en la creación de la poética literaria moderna.

PALABRAS CLAVE: Tasso; Milton; creación; maravilla; lo sublime. sublime na formação da poética literária da idade proto-moderna.

PALAVRAS-CHAVE: Tasso; Milton; criação; maravilha; o sublime.

\section{The making of the sublime in the Fiat LuX}

In chapter nine of his famous tractate $\mathrm{O}$ the Sublime (Peri H ypsous), Longinus quotes the fiat lux passage from Genesis in order to define what the sublime is. By praising the exceptionality of the author of Genesis ("no ordinary man"), Longinus remarks that "[M oses] writes at the very beginning of his Laws: 'God said'-what? 'let there be light,' and there was light, 'Let there be earth,' and there was earth" (9.2). The quotation from Genesis 1.3 is of undeniableinterest, not only for the presence of the Scriptures in a Hellenistic rhetorical tract, but also because Longinus suggests the author's inventive power to construct a poetics of transcendence. What Longinus points out as exceptional is not Moses' rhetorical ability to represent God's creation, but-through his interrogative ("what?")-Moses' mastery to upstage the experience of creation with a sublimity analogous to that performed by God in bringing the world into existence (Porter 2016). The sublime is, therefore, the magnanimous power of the writer to produce a transcendental experience in himself and in the reader alike. The fiat lux passage exemplifies how the author of Genesis recreates in the text an experience of wonder and astonishment, which is comparable to the amazement caused by God's creation in nature.

The link between the fiat lux and the notion of sublimity regains importance again in modernity when the $P$ eri $\mathrm{H}$ ypsous reemerges with Nicolas Boileau's French translation, T raitédu sublime ou du merveilleux dans le discours, in 1674. In this treatise, Boileau considers the fiat lux to be the hallmark of true sublimity for its simplicity, so much so that fiat lux is the only quoted passage from Longinus's text. However, Boileau's most influential imperative on Longinus is his distinction between the sublime styleand the experiential sublime. In addition to its rhetorical meaning, the sublime, for Boileau, is an elevating experience for the reader as a result of the writer's magnanimous mind: the sublime, he claims, "enlève, ravit, transporte" (318).

Despite the centrality of Boileau's interpretation, the Longinian text circulated long before the French translation, starting with Francesco Robortello's editio princeps (1554), which contributed to the 
revival of the sublime in conceptual and experiential patterns. ${ }^{1}$ With the availability of the Hellenistic treatise in the sixteenth century, Renaissance writers incorporated the Longinian idea of the sublimeas ravishment, elevation, and transport in their imagery (Cheney 2018). In this regard, Tasso's II mondo creato (1594, published posthumously in 1607) and Book 7 in Milton's Paradise Lost (1667) are two of the most representative examples of how Renaissance authors merged the sublime, as an experience of transcendence, with the account of biblical creation. Both texts belong to modern hexameral literature, which represents poetic creation as anal ogous to the divine making of the world. ${ }^{2}$ By celebrating the beauty and variety of the created universe, hexameral poetry also praises the ability of the poet to represent the experience of God's molding process. Tasso's and Milton's poems celebrate the wonders in nature and identify the narration of origins as the source of an experience of the divine. ${ }^{3}$

The account of creation in II mondo creato represents the poet's occasion for transport, namely, his ability to transcend to mental and moral heights: "Così chi di celesti obietti eterni | E de le cose smisurate e grandi | Mira le meraviglie," that is, the poet, "Convien cheseco, anzi in sé stesso, apporti| Gli impeti interni, e'I vivo ardore,

\footnotetext{
${ }^{1}$ For an expanded history of the reception of Longinus's Peri Hypsous see Fumaroli (1986) and Goyet (1991).
}

${ }^{2}$ Hexameral literature was a popular genre in the early church and the Middle Ages. Basil of Caesarea wrote a commentary on Genesis in his Exameron, which became the source of Saint Ambrose's H exameron, and Saint Augustine wrote D e Genesi ad litteram on the first three chapters of Genesis. Though not an hexameral poem, Dante's Divina commedia alludes to biblical creation throughout his poem. In light of the new astronomical and geographical discoveries, poetry about Creation reaches a climax between 1562 and 1667, starting with MauriceScève's M icrocosmeand Guillame Sall luste Du Bartas's La sepmaine, ou Création du monde (1578) in France. Du Bartas's hexameral poem inspired Tasso, who read La sepmaine in its Latin version. A lonso de A vecedo uses Du Bartas's and Tasso's poems as models for his De la Creación del M undo (1615). Milton's account of the creation in Book 7 of Paradise Lost concludes this prolific period for hexameral literature (Boitani 2007, 79-90).

${ }^{3}$ Given that Tasso and Milton write in a period antecedent to the eighteenth-century theorization of the sublime, it is important to differentiate the specific term "sublime" from a poetics of the sublime, including an array of ideas, images, themes, and patterns. For clarity, I will use Patrick Cheney's working definition of the Longinian sublime as literary greatness $(2018,16)$. By literary greatness, Longinus means artistic excellence in creating an experience of transport in the character, the author, and the reader alike. In other words, true grandeur in literature activates the transformative potential of the human mind to reach beyond immanence. 
e "I zelo | Fervido, a contemplar rivolto e fisso | Tai cose e tante" (4.14-22). " "Impeti interni," "vivo ardore," "zelo fervido" areall terms that describe meraviglia as the poet's intuitive experience of creativity and elevation and evoke Longinus's effects of transport and wonder from the genius to his audience. ${ }^{5}$

Following the Longinian tradition, Milton reveals his intention to compose his story of the origins in a sublime style: "I thence | Invoke thy aid to my advent'rous song,| That with no middle flight intends to soar| Above the Aonian mount, while it pursues | Things unattempted yet in prose or rhyme" (Paradise Lost, 1.12-16). The English poet declares that his subject matter is manifestly sublime ("advent'rous" and "unattempted") 6 and, therefore, demands a lofty style. ${ }^{7}$ A longside Tasso, Milton understands the sublimity of biblical creation not only in terms of elevated diction, but also as an experience of transcendence. However, despite his indebtedness to Tasso, the author of Paradise L ost chooses not to represent the creation in Book 7 as a source of ecstatic elevation and interpretation. Rather, Milton locates the sublimity of art and nature in a more dialogical, if not dialectical, compositional model.

Rooted in the Longinian combination of artistic and divine creation within the sublime, II mondo creato and Paradise Lost share the same premise in their representations of God's fashioning of the world. Their paths to sublimity, however, differ greatly and these divergences will be the object of scrutiny in the present essay.

\footnotetext{
${ }^{4}$ English translation from Tusiani in Tasso (1982): “Thus he who gazes on the rare delights | of all these heavenly eternal things, | so mighty and so measureless and pure | [...] quickly agrees he must within himself | have the same fervor, harbor the same zeal | to contemplate with rapt attention all | such mighty things."

${ }^{5} \mathrm{O} n$ the Sublime, 1.4: "For the effect of genius is not to persuade the audience but rather to transport them out of themselves;" 8.1: "the second [source of the sublime] is the inspiration of vehement emotions."

${ }^{6}$ Theword "unattempted" translates Ariosto's expression "cosa non detta in prosa mai, né in rima" (O rlando furioso, 1.2). The Italian epic tradition and theory, along with the classical legacy, exerted a strong influence on Milton's Paradise L ost.

7 The expression "middle flight," as David Quint explains, evokes the "middle way" (medio in Latin) that both Ovid's A pollo and Daedalus recommend their sons Phaeton and I carus as the safest course to fly (M etamorphosis 2.137, 8.203). In this regard, Milton distances himself from Du Bartas's cautious invocation of the Muse for "the middle Region" (D ivine W eeks, I.1.136) in Joshua Sylvester's translation (Quint 2014, 89).
} 


\section{Meravigliaand ekstasisin Tasso}

Tasso's involvement with the Longinian tractate is still a debated question given the lack of direct references to the ancient text. However, recent work has suggested that $0 \mathrm{n}$ the Sublime might have exerted an influence on Tasso's poetic theory either directly through Robortello's editio princeps (1554) and Pagano's Latin translation (1572), or indirectly through the many allusions to Longinus in the commentaries by Pietro Vettori (Commentary on A ristotle, 1560; Commentary on Demetrius, 1562) and Francesco Patrizi (D ella Poetica, 1586) (Graziani 1996, 122-23; Doran 2015, 104; Lehtonen 2016, 455). This is not to neglect the importance of other Hellenistic rhetoricians such as Demetrius or to deny the presence of A ristotelian thought in Tasso's poetic theory, but to suggest that, in his later career, Tasso's idea of literature was also informed by some Longinian elements. Tasso drew on the Longinian model of the sublime and incorporated it into his concept of meraviglia merging it with the pattern of divine and artistic creation.

Tasso's meraviglia was an idea that developed over time in his career from his prose writing, Discorsi del poema eroico, published in the same year he most likely concluded II mon do creato, his last work. The understanding of wonder, marvel, and admiration in the Renaissance, according to the orthodox perspective, was based on Aristotle's M etaphysics and Poetics (Platt 1992, 387-88). Francesco Robortello, Antonio Minturno and Giovambattista Giraldi Cinthio maintained that wonder was a necessary component in poetry and was most effective when marvelous moments occurred unexpectedly (Aristotle's P oetics 1452a). Tasso made wonder the hallmark of epic poetry, which he defined as the imitation of a noble action, narrated in the loftiest style and with the purpose of "muovere gli animi con la maraviglia, e di giovare in questa guisa" (D iscorsi, 508). ${ }^{8} \mathrm{M}$ eraviglia, for Tasso, is the final aim of the epic genre not merely because of aesthetic pleasure. The Italian poet invokes a much more complex experience than delight ("giovare") when using the term "wonder": meraviglia makes the readers "attoniti" [astonished] (506) and fills their minds "di tumulto e di perturbazione" [with turmoil and perturbation] (712). In other words, wonder is the author's capacity to

${ }^{8}$ D iscourses, 17: "moving the mind to wonder and thus being useful." 
create an experience of transport that overwhelms the reader. In a similar vein, Longinus affirmed in his tract:

what inspires wonder, with its power of amazing us, al ways prevails over what is merely convincing and pleasing. For our persuasions are usually under our own control, while these things exercise an irresistible power and mastery, and get the better of every listener. (On the Sublime, 1.4)

Longinus places the irresistible power to astonish in the author's nobility of mind. In the same chapter in which the fiat lux citation is found, Longinus claims that "sublimity is the echo of a noble mind" (9.2). The author's capacity to excite wonder depends less on his technical skills than on his genius, his magnitude animi. Analogously, meraviglia in Tasso invokes, as Françoise Graziani explains, the "pouvoir contenu dans l'altezza d'ingegno du poète" (1996, 131). ${ }^{9}$ The poet's intellectual height ("altezza"), which recalls Longinus's term for sublimity hypsos (Doran 2015, 105), is infused by God and emanates from the genius to his audience:

O possa io pur, sì come guida e scorta

Ch'ignoto peregrin conduce intorno,

E gli edifici ele mirabili opre

Di famosa città gli addita e mostra,

Così condur le peregrine menti

De' mortali, qua giù mai sempre erranti,

A le sublimi meraviglie occulte

Di questa ampia città, di questa io dico

Città celeste, ove è la patria antica

Di noi figli d'Adamo, el'alta reggia

In cui gli eterni premi il Re comparte. (II mondo creato, I.76-86) ${ }^{10}$

For Tasso, it is through the emulation of the genius's mind that the reader is raised to a higher mental plane, reaching the vision of the sublime, heavenly city. M eraviglia represents the contemplative experience of elevation whose effects reverberate from the inspired poet to his audience: “Cosi possiam ne l'invisibil luce | Conoscere il

\footnotetext{
${ }^{9}$ Tasso uses the expression al tezza d'ingegno in his Lezione sopra un sonetto di monsignor D ella Casa (Tasso 1875, 122).

10 "And may I also, likea leading guide | who to an unknown passenger makes known | the palaces and wondrous monuments| of a most famous city, now escort| themortal minds till tarrying on earth | to the sublime, concealed magnificence | of this wide City-the celestial Home | that is the ancient fatherland of all | the sons of Adam, and the lofty court where| the King bestows his heavenly rewards."
} 
gran Dio che fece il mondo, | Come dal contemplar la nostra mente | A conoscer la sua leviamo in alto" (6.1615-18). ${ }^{11}$

Tasso's notion of imitation resembles Longinus's concept of zelosismimesis ( $0 \mathrm{n}$ the Sublime, 13.2), rather than Aristotle's concept of imitation. Just as Longinus understands emulation as a competition between past models and the poetic desire for innovation, ${ }^{12}$ the contemplation of the created world in II mondo creato is compared to the physical competitions in tournament and joust ("le contese," "i duri incontri," 4.1, 6). Before the contest, the observer feels "un movimento interno | Ond'è commosso e concitato insieme con quei che fan tra loro duro contrasto" (4.7-9). ${ }^{13}$ Like the Longinian sublime, Tasso's meraviglia is measured by its forcefulness and the powerful effect it exerts on the reader rather than by its rhetorical ornament and exalted eloquence.

Furthermore, a new linguistic and formal phase is inaugurated in II mondo creato, under the influence of Longinus's fiat lux. ${ }^{14} \mathrm{M}$ eraviglia is found in the wonders of creation, as in the fiat lux passage, instead of in the unexpected, the incredible, or the monstrous as in the Gerusalemme liberata (Leo 1954, 9-10). The variatio of style does not hinge on overabundance and the multiplicity of tones; it is not shaped on the contrasts generated by oxymorons, antitheses, and paradoxes, as in the Liberata; rather it is modulated by a regular and rhythmical cadence of language, which privileges repetition in any form (Leo

11 "We in the light invisible at last | can know the mighty Maker of the world | if with our minds we soar to contemplate| His lofty thought."

${ }^{12}$ Longinus clearly expresses the agonistic dynamic of imitation in his description of Plato's brilliant style. Plato would never have achieved his mastery in the philosophical doctrines nor his grandeur in language, Longinus maintains, "had he not striven, with heart and soul, to contest the prize with Homer, like a young antagonist with one who had al ready won his spurs [...] the fight for fame well worth the winning, where even to be worsted by our forerunners is not without glory" ( $0 n$ the Sublime, 13.4). For Milton's notion of the sublime as a dialectic competition see further in this article.

13 "H efeels in his soul a deep enthusiasm | that agitates and rouses all of him | together with the men who fiercely fight."

${ }^{14}$ Before citing the Old Testament, Longinus celebrates Homer's superior ability to produce admiration and powerful emotions in a simple image such as Ajax's silence in the 0 dyssey (11.549-64) without necessarily using an elevated diction or bombastic el oquence ("thoseempty inflations, void of sincerity," O n the Sublime, 3.2): "How grand, for instance, is the silence of Ajax in the Summoning of the Ghosts, more sublime than any speech!"(9.2). A similar modus scribendi, that is, a simpler, unadorned style, characterizes Tasso's last work. 
1954, 15). In terms of style, iterative does not mean monotone or monothematic; in fact, Tasso preserves the idea of variety in the created world. Yet, he gives new shape to multiplicity by placing it in a unified and orderly language. The more uniformed language of II mondo creato reproduces the language of the Bible: it is condensed, sober, sacral and highly iterative, particularly in the account of creation (resembling the phrases in Genesis: "God said," "God saw that it was good").

Iteration in all its forms-anaphora, epistrophe, anadiplosis, amplifications and accumulations-is indeed the dominant rhetorical figure in Tasso's work on creation: "un sistema retorico geminativo," as Rosanna Morace has defined it, a language that magnifies itself through repetition $(2016,133)$. This is the rhetorical property of Tasso's fiat lux in the first day of the creation of the world:

E disse, Fatta sia la luce; et opra

Fu il detto al comandar del Padre eterno,

Né'I suo parlar suon di snodata lingua

Né percossa fu già chel'aria imprima

Di sé medesma, e di sua voce informi,

Ma del santo Voler, ch'a l'opre inchina,

Quell'inchinarsi è la Parola interna.

Così la prima voce e'I primo impero

Del gran Padre del cielo criò repente

La chiarissima pura ebella luce

Che fu prima raccolta, e poi divisa

E 'n più lumi distinta il quarto giorno. (II mondo creato, I.533-44) ${ }^{15}$

Repetition characterizes every aspect of the passage. Epanalepsis connotes the very beginning of God's creation of light: disse, detto. The word "dire" is a key verb in the process of creation and its significance is reiterated through the use of words belonging to the same semantic area: "parlar," "suon," “lingua," "voce," "Parola," and again "voce." The effects of God's utterances are marked by the anaphora of "neither" né il suo parlar | né percossa fu, the alliteration of the same

\footnotetext{
15 “He said, 'Let there be light!' His word was law, | for the Eternal Father is obeyed. | But, though resembling a full-sounding tongue, | his word was not a blow that prints itself | upon theair and shapes it with its voice: | it was his holy will's innermost sound | which he bent down into activity. | Thus the first voice and thus the first command | of the great Heavenly Father made at once | the purest, and the clearest, fairest light, | which first was held together, and then split | in several separatelights on the fourth day."
} 
prefix in- ("imprima," "informi," “inchina”), by epanalepsis ("opra," "opre"; "inchina," "inchinarsi") and the insistence of the adjective "first" ("prima voce," "primo impero," "prima raccolta"). Looking at the text from a phonic approach, the representation of light is forged on an alliterative chain with the letter ' $s$ ': "Né 'I suo parlar suon di snodata lingua | Né percossa fu già che l'aria imprima | Di sé medesma, e di sua voce informi, | Ma del santo Voler, ch'a l'opre inchina, | Quell'inchinarsi." God's light emanates like a whisper, which is pronounced with a single, uninterrupted voice and, in doing so, the Father causes the creation of the world by diffuse reflection. God is light, and he manifests himself in the universe through the reflection of his own light: "O bellissima luce, o luce amica | De la natura e de la mente umana, | De la divinità serena imago" (1.56264). ${ }^{16}$

In a letter addressed to Scipione Gonzaga written in 1578, the same year Tasso was imprisoned in Sant'Anna, which also marks the beginning of his religious crisis leading to the writing of II mon do creato (Luparia 1987), the poet maintains that, "non potendo affisar gli occhi nel sole, rimira ne l'acqua l'imagine de la sua luce" (Lettere, 123). Unlike Paul or Moses, he is denied the privilege of seeing God "a faccia a faccia." Instead, "in guisa d'uomo" [like a man], he is permitted to see the reflection of divine light in the things God created. It is no coincidence that the verb Tasso uses, "rimirare," to explain the way mankind gains knowledge of God-by gazing at the reflected image of his light-is formed from the prefix ri-, whose function is to reiterate the meaning of the verb it accompanies, and from the verb "mirare," to gaze attentively and, often, with wonder, as in Dante's "rimirando in Dio" (Paradiso VIII.90). Therefore, "rimirare," to gaze with admiration (a synonym of "ammirare," to look with admiration), does not merely produce surprise at the magnificence of the created universe; it denotes more than a poetic emotion or an aesthetic pleasure. The verb "rimirare" describes, according to Tasso, the cognitive process of contemplative admiration through which God is revealed. For the poet, to feel wonder is to experience, by analogy, the same enthusiasm and grandeur of the act of creation and, through reflection of wonder, to know the essence of the divine. The act of "rimirare," in other words, combines an intense

16 "O beatific luster, friendly light | of nature and man's mind, sweet image of | divinity." 
and transformative moment of wonder with an experience of enhanced comprehension of transcendence. Within this single experience, Tasso merges the cognitive aspect of Plato's and A ristotle's thaumaston with the Longinian ekstasis ${ }^{17}$ and the Christian experience of religious rapture. ${ }^{18}$ Tasso's artistic creation might be described as a poetics of illumination and, for this reason, Francesco Guardiani has claimed that "light" is the most recurrent word in the poem $(1986,220)$.

Yet, II mondo creato does not culminate in a circuitus spiritual is that unites God with the world. Divine essence is ultimately defined in terms of "invisibil luce" (II mondo creato, 6.1615, 7.375) so much so that the poem concludes with a sublimely tragic prayer to the Deus absconditus: "Dove sei? dove sei, chi mi ti asconde? | Chi mi t'invola, o mio Signore e Padre?" (7.1111-12). ${ }^{19}$ The end of creation engenders a sense of new beginning: this will be the time when the Deus absconditus answers the world's prayer. Tasso's questioning of God is not the result of his individual distress, the voice of a tired and melancholic author at the end of his poetic career. Instead, the end of II mondo creato embodies a more collectiveawareness about the closure of an era affected by religious and social skepticism (Scianatico 1994, 81), a world that Tasso describes as "stanco e veglio" ("weak, aging world" 7.1124).

${ }^{17}$ Ekstasis, for Longinus, occurs when the individual is drawn to a higher level of knowledgethrough intuition. This process of spiritual growth connects the subject with the grandeur of the universe and with a transcendental reality. Cf. Halliwell (2012, 330 ff.).

${ }^{18}$ Erminia Ardissino has eloquently explained thefunction of wonder in Tasso's poetics. Although she refers to Tasso's theorization of wonder in the D iscorsi, her definition of Tasso's poetics of meraviglia also applies to II mondo creato (2003, 23-24): “L'ingresso dell'elemento gnoseologico nei Discorsi dell'artepoetica, [...] si rivela [...] nelleriflessioni sul meraviglioso [...] fondando poesia e sapere. [...] meraviglia implica il superamento dell'ordine puramente estetico delle cose e della storia per congiungerlo con l'ordine metafisico, oltre che etico. La meraviglia è sorpresa per il mistero e desiderio di comprenderlo, risveglia interesse per la dimensione che è velata dietro ciò che la desta. La riflessione sul meraviglioso trova l'al tro in accordo Platone con A ristotele, attenti al valore cognitivo del thaumaston [Cf. Platone, Teeteto 155d; Aristotele, M etafisica 282d], ma apre anche alla fede per la soluzione del «maraviglioso cristiano». La meraviglia pone in concordia verosimile e sublime, verità e fantastico, unità e varietà, sensi e intelletto: è l'incontro della dimensione sensibile con quella intellegibile."

19 "Where are You? Oh, where are You? | Why do You hide from me, or who or what | takes You from meaway, my Lord and Father?" 


\section{The construction of the sublime in Paradise Lost 7}

Tasso's lasting impression of the end as a new beginning lays the foundation for Milton's Paradise Lost, a poem that imagines the creation of the world from the perspective of its end. While one would expect to read about the creation of the world at the beginning of the poem, creation is not fully described until Book 7, after the account of the angelic fall. This inversion of the biblical order is repeated throughout the poem: first it is seen through the angelic fall in Books 1 and 2 followed by Uriel's account of creation in Book 3; then Raphael recalls the war in heaven and the fall of the rebellious angels in Book 6 followed by his creation narrative in Book 7; then the fall of A dam and Eve in Books 9 and 10 is followed by Michael's disclosure of a new creation and the coming of our first parents into the world in the final books (Schwartz 1993, 2-3). As for Longinus's interpolation in the fiat lux passage ("God said" - what?), Milton's variation from the order of the Scriptures foregrounds a process of re-creation. Literary creation is, for Milton, an act of origin, but every poetic act is also a repetition, a re-presentation, a re-production. Therefore, to write about the biblical origin is al so to write about the biblical origins in the Scriptures and to recount the many rewritings that preceded Paradise Lost.

Milton had read Tasso and included the Italian author among his models for epic poetry (The Reason of Church Government in CPW 1, 813). ${ }^{20}$ Certainly, Milton had $\mathrm{II}$ mondo creato in mind when he composed the invocation to light in Book 3 of Paradise L ost: " Hail holy light, offspring of heaven first-born, | Or of the eternal co-eternal beam | May I express thee unblamed?" (3.1-3). The first two verses echo the protasis of Tasso's creation poem, which celebrates the coeternity of the Son to his Father: "Padre del Cielo, etu del Padreeterno | Eterno figlio, e non creata prole" (1.1-2). The style of the passage is very similar to the fiat lux description in II mondo creato:

Hail holy light, offspring of heaven first-born,

Or of the eternal co-eternal beam

May I express thee unblamed? Since God is light,

And never but in unapproached light

\footnotetext{
${ }^{20}$ Many critics have illustrated the debt of Milton to Tasso for epic theory and practice, although they focused on the relation between Paradise Lost and Gerusalemme liberata, see Steadman (1976), Patterson (1971), Kates (1983), Quint (2014). Lehtonen (2019) has recently discussed the presence of the sublime in the two epic poems.
} 
Dwelt from eternity, dwelt then in thee,

Bright effluence of bright essence increate.

Or hearst thou rather pure ethereal stream,

Whose fountain who shall tell? Before the sun,

Before the heavens thou wert, and at the voice

Of God, as with a mantle didst invest

The rising world of waters dark and deep,

Won from the void and formless infinite. (Paradise Lost, 3.1-8)

There are many patterns of repetitions: the alliteration of $h$ in verse 1 ("H ail holy light, offspring of heaven first-born"); epanalepsis ("light" is repeated three times in the first four verses; verse 5: "dwelt: dwelt"; verse 6: "bright: bright"); epistrophe (again "light" at theend of verses 3 and 4 and the prefix in-: "increate," "invest," "infinite"); polyptoton (eternal in verse 2 is repeated with a different function); anadiplosis ("Before the sun" / "Before the heavens"); accumulation of words within the same semantic area (light, beam, effluence; stream, fountain, waters). Similarly, Tasso's description of fiat lux heavily relies on rhetorical and rhythmic repetition, which is in fact a characteristic of the biblical style itself. Like Longinus, whom he names in his tract $0 f$ Education, Milton also recognized the sublimity of the biblical style to convey grand thoughts and images through a condensed and uniformed language. In 0 f R eformation, Milton praised "the sober, plain, and unaffected style of the Scriptures" (CPW 1,568) and in De Doctrina Christiana he favored the author of the Epistle to the Hebrews as the one who proclaims sublimely, "The generation of the divine nature is described by no one with more sublimity and copiousness than by the apostle to the Hebrews, i. 2, 3" (The Christian D octrine, 934-35). Yet, Milton added a further dimension to the bi blical pattern of iteration: he expanded the mechanism of repetition into a repetitive pattern of opposites. While, for Tasso, repetition as diffuse reflection symbolizes how divine essence is revealed in the created world, according to Milton, man experiences transcendence in the form of repeated opposites (Lieb 1970). Therefore, poetic creation in the fallen world does not operate without its opposite: destruction or un-creation. ${ }^{21}$ As soon as Milton addresses the light in Book 3, he dramatically thematizes his possible failure: "May I express thee unblamed?" The process of creation is continuously threatened by

${ }^{21}$ Un-creation threatens the process of creativity at all levels in Paradise Lost, for example, Satan symbolizes un-creation and destruction. Here I choose to focus on creation from an authorial perspective. 
moments of darkness and chaos. Thus, in the invocation to light, Milton raises the specter of his own blindness to express his fear of the failure of language:

[...] but thou;

Revisitst not these eyes, that roll in vain

To find thy piercing ray, and find no dawn

So thick a drop serene hath quenched their orbs,

Or dim suffusion veiled. (Paradise Lost, 3.22-26)

[...] but not to me returns

Day, or the sweet approach of even or morn,

Or sight of vernal bloom, or summer's rose,

Or flocks, or herds, or human face divine;

But cloud instead, and ever-during dark

Surrounds me, from the cheerful ways of men

Cut off, and for the book of knowledge fair

Presented with a universal blank

Of nature's works to me expunged and razed,

And wisdom at one entrance quite shut out. (3.41-50)

Milton's poetic ambition can be fulfilled only by inward illumination: "thou celestial light | Shine inward [...] that I may see and tell | Of things invisible to mortal sight" (3.50-51, 54-55). Yet again, the confidence in his poetic endeavor fades away by the invocation in Book 7, which announces the song of world creation (Schwartz 1993, 61). Light encounters the threat of darkness, the fiat lux narration is created out of fiat obscuritas. Milton's poetic process of re-creation originates under the threat of two vivid images of failure: one is Bellerophon (Paradise Lost, 7.17-20), who was blinded after he had tried to fly to heaven riding Pegasus, the other is Orpheus (7.32-38), whose harp and voice were drowned by the worshippers of Bacchus. Milton's fiat lux struggles against the risks of being unseen or unheard.

Writing in the wake of new worlds and the new science of Galileo, Montaigne, and Descartes, and the epistemological challenges they posed, Milton inherits a skeptical attitude towards the ability of language to convey origins at all (Ramachandran 2015, 183). The sense of ending characterizing Milton's narrative of the beginning corresponds to a cultural change in modernity within the concept of artistic invention. On the one hand, the focal point in the act of creation gradually shifts from God to the human and, for this reason, Teskey has pointed out that "Milton is the last great poet in the European literary tradition for whom the act of creation is centered in 
God" (2006, 29). This change, on the other hand, undermines the analogy between artistic and divine creation: when human inventive power no longer resembles thegreat Maker, theindividual's authority to create is critically put into question. As a result, Milton's creation stories are always mediated by accounts of accounts and by the presence of "divine interpreter[s]" (Paradise Lost, 7.72) such as the archangels. Raphael is the figure of mediation to whom God entrusts the tale of creation. A fter the prologue, A dam demands the archangel inform him, "How first began this heaven which we behold" (7.86). The creation narrative originates from its opposite: Satan's own destruction. By recounting the story of the war in heaven, as narrated in Book 6, Raphael reiterates the idea that creation depends on its opposite, "Good out of evil to create" (7.188). Thus, from Satan's fall, God "in a moment will create| A nother world" (7.154-55). In fact, the divine performative utterance of creation is pronounced by God, but it is given effect through the mediation of his Son, who would later join his nature to mankind in order to redeem their sins (3.82-83): "So spake the almighty, and to what he spakel His Word, the Filial Godhead, gave effect" (7.174-75). In one of his most sublime images, Milton describes the Son who, like an architect, holds "the golden compasses" and sets the bounds of the universe:

He took the golden compasses, prepared

In God's eternal store, to circumscribe

This universe, and all created things:

One foot he centred, and the other turned

Round through the vast profundity obscure,

And said, Thus far extend, thus far thy bounds,

This be thy just circumference, $\mathrm{O}$ world.

Thus God the heaven created, thus the earth. (7.225-32)

While creation necessarily results from fall, and good originates from evil, Raphael demonstrates that, "to create| Is greater than created to destroy" (7.606-7). Sublimity, for Milton, lies in the higher union of opposing arguments. Poetic creation is the re-presentation of a dramatic dialectic, while sublime creation is the attempt to polarize the terms of this dialectic into harmonious synthesis (Radzinowicz 1978). In this regard, Milton understands sublimity in Longinian terms as an agonistic dynamic. Although Longinus describes the author's grandeur as a secularized version of divine inspirationsublimity originates from "Zealous imitation of the great prose writers and poets of the past" ( $0 \mathrm{n}$ the Sublime, 13.2)-he emphasizes 
that emulation does not imply a passive veneration for past models. Longinus's inspirational process to create sublime poetry emerges from the rival ry between the admiration for the past and the creative urge to subvert and exceed the tradition (Doran 2015, 65-67). Theagon between admiration and deviance from the illustrious past represents the essence of sublime creation, for Longinus as well as for Milton. In this regard, David Quint has uncovered, for instance, how Book 3 pivots around the opposition between the poet's internal illumination and the Apollonian light, which inspires pagan poetry as in the Homeric H ymn to A pollo and Callimachus's H ymn to A pollo $(2014,98)$. In one of his most famous early tracts, A reopagitica, Milton affirms that in order to ascertain truth and to gain knowledge, one has to engage in the "sublimest points of controversie" (CPW 2, 557). Therefore, from an ethical standpoint, knowledge advances out of an active engagement with evil. Similarly, on a literary level, sublime poetry emerges out of a dialectical writing that displays oppositions and creates polarities. The construction of a poetics of sublimity depends on a persistent exercise of choice for the author and for the reader alike.22

In Paradise L ost, sublimity originates from the creation of dialectical patterns and, in this light, it differs from Tasso's concept of wonder as an intense emotional moment of transcendence. Indeed, Milton recognizes the importance of sublime inspiration in the poetics of creation. His deep commitment to sublime style is evident in his intention to recount "Things unattempted yet in prose or rhyme" (1.16), as he writes at the beginning of Paradise Lost, but the English author is also very conscious of the risks of flying al oft under the spell of divine inspiration. ${ }^{23}$ For this reason, he distances himself from Tasso's idea of meraviglia as a contemplative and solitary kind of

\footnotetext{
${ }^{22}$ Reading Paradise L ost as a poem about choosing is a traditional hermeneutic strategy; see Lewalski $(2003,460)$ and Fish $(2001,547)$. Yet, what has been overlooked is the relation between the poetics of sublimity and the exercise of choice in Milton's poem. A thorough analysis and discussion of the topic would require a whole book, therefore I will concentrate on the role of the author, rather than the reader, in the construction of the sublime. For the sublime as a theory of reading see Porter $(2016,117-24)$.

23 During the English Restoration, sublimity was also associated with a kind of fanaticism based on a claim of divine inspiration. Milton had polemicized with enthusiasts and fanatics in his prose works. Heshows heis fully aware that enthusiasm is potentially dangerous when associated with the claim of divine inspiration in the images of the fallen Bellerophon and the murdered Orpheus in Book 7. For the relation between enthusiasm and the sublime see Achinstein (2003, 154-81).
} 
Longinian ekstasis-a transformative and enlightening moment of consciousness. Milton's understanding of divine truths emerges from a material sublime: the Son, as the divine architect, creates the universe by number and proportion, marking thelimits of the infinite out of chaos. ${ }^{24}$ Likewise, Adam learns from Raphael that the proper method for understanding the invisible and the incomprehensible is to pore over materiality, reminiscent of Milton's writing in of Education (CPW 2, 368):

Heav'n is for thee too high

To know what passes there; be lowly wise:

Think only what concerns thee and thy being;

Dream not of other worlds, what creatures there

Live, in what state, condition or degree.

[To which A dam replies:]

[N ]ot to know at large of things remote

From use, obscure and subtle, but to know

That which before us lies in daily life,

Is the prime wisdom; what is more, is fume,

Or emptiness, or fond impertinence,

And renders us in things that most concern

Unpracticed, unprepared, and still to seek.

(Paradise Lost, 8.173-76, 191-97)

Raphael's description of creation concludes with an emphasis on the human and the physical world. If Milton is the last great poet, in the Western epic tradition, to write about God's making of the world, he is also the first modern author "for whom the act of creation begins to find its center in the human" (Teskey 2006, 29). For this reason, his sublime poetry represents the most original expression of the analogy between poetic and divine creation, and yet, it also anticipates the profound gulf between God's act of making and the authority of human creativity.

\footnotetext{
${ }^{24} \mathrm{~A}$ long and fruitful relation between sublime poetry and natural philosophy has been recently investigated in Porter's monumental work The Sublime in Antiquity (2016). Lucretius is a fundamental link within this tradition of the natural sublime. For the Lucretian influence on Paradise Lost see Hardie (2009) and Quint (2014), although an account of Lucretius's impact on the topos of poetic creation still needs further investigation.
} 


\section{Conclusion}

The examples taken from II mondo creato and Paradise Lost have illustrated how the two poems are alike in considering the fashioning of the world in the Scriptures as a source of rhetorical and experiential sublimity. In their interpretations of the fiat lux, in particular, Tasso and Milton recognize that the narration of the divine command "Let there be light" is not only an example of sublime, elevated rhetoric, but it is also an occasion to reveal the grandeur of a poet's mind, as for the author of Peri Hypsous (9.2). The source of sublime poetry, for Tasso and Milton, is divine light that works through inner illumination to inspire and elevate the poet to an experience of transcendence. The capacity of the poet to create an intense moment of transport, which shortens "the distance between earth and heaven" (On the Sublime 9.4), has a strong emotional impact also in the reader or listener, as Longinus explains in this tractate (1.4). This elevating and overwhelming effect on the reader is the result of the communication of the writer's magnanimous soul through the power of his sublime poetry. However, Tasso and Milton diverge in the way in which they conceive of the transmission of their inspired grandeur and in their respective formulations of the experience of sublimity.

In Tasso's II mondo creato, meraviglia describes the exceptional contemplative transport of the mind, which experiences the sacred by contemplating the traces of the heavenly in the created world. Divine light descends in the spirit of the poet ("nel mi o cuore al berga" 1.21) whoseartistic creation elevates him to the contemplation of the divine. This singular and individual feeling of momentary transcendence of the human condition, affecting both the poet and the reader, produces meraviglia or ekstasis, as Longinus calls the concomitance of astonishment and wonder ( $\mathrm{n}$ the Sublime, 1 ).

Rather than an exceptional and contemplative moment, in Milton's Paradise Lost, sublimity describes a dialogic, often dialectic, confrontation between opposing images, characters, and narrations. As in Tasso's poem, the Miltonic sublime originates from an extraordinary mind inwardly moved by divine light; yet, Milton's notion of sublimity is also indicative of a certain skepticism towards the Longinian notion of ecstasy. The origins of sublime creation in Paradise Lost lie more in Longinus's idea of mimesis as an agon: representation means emulating and repeating the original text by 
staging opposing values, images and contrasting voices, and then resolving them into a synthesis.

Furthermore, the two kinds of sublimity in II mondo creato and $P$ aradise Lost diverge in the relation between poetic creation and matter. Whereas, for Tasso, wonder represents the tendency to move from matter into the transcendental, Milton's sublimity focuses on the materiality of the created universe to mark its distance from immateriality. According to the English poet, mankind's understanding of the divine should be grounded in the physical world, since the divine can only be reached through its radical otherness from matter.

Despite their differences, Tasso's meraviglia and Milton's sublime are alike in their origins-since the experience of being exalted and overwhelmed passes through the materiality of the created worldand they converge again in their mutual yearning for transcendence. Milton's descent into the very heart of matter at the time of its creation aims to grasp the essence of the immaterial through its opposite. By the same token, Tasso's transcending trajectory recoils from matter into something higher, but then turns back into the physical world in order to retrace the presence of the divine within immanence. The fact that the two authors vacillate between one extreme and the other is not to be understood as a sign of their distance. Instead, the reason for this vacillation lies in the very nature of the Longinian sublime, which resides in the tension between immanence and transcendence, materiality and immateriality. By rewriting thefiat lux scene of biblical creation, these two poems by Tasso and Milton are closely related in their attempt to represent the cosmic gap that measures the distance between earth and heaven.

\section{References}

Achinstein, Sharon. 2003. Literature and Dissent in Milton's England. Cambridge: Cambridge University Press.

Ardissino, Erminia. 2003. “PerchéPlotino." In Tasso, Plotino, Ficino. In margine a un postillato, edited by Erminia Ardissino, 13-30. Rome: Edizioni di Storia e letteratura.

Ariosto, Ludovico. 1997. Orlando Furioso e i Cinque canti. Edited by Remo Ceserani and Sergio Zatti. Torino: UTET. 
Boileau-Despréaux, Nicolas. (1674) 2007. Traité du sublime ou du merveilleux dans le discours. In 0 euvres completes. Paris: Firmin Didot Frères [Elibron Classics Replica].

Boitani, Piero. 2007. Prima lezione sulla letteratura. Rome-Bari, Laterza.

Cheney, Patrick. 2018. English A uthorship and theEarly M odern Sublime. Fictions of Transport in Spenser, M arlowe, Jonson, and Shakespeare. Cambridge: Cambridge University Press.

Doran, Robert. 2015. The Theory of the Sublime from Longinus to Kant. Cambridge: Cambridge University Press.

Fish, Stanley. 2001. H ow M ilton Works. Cambridge, MA: Harvard University Press.

Fumaroli, Marc. 1986. "Rhétoriqued'écoleet théoriqueadulte: Remarquessur la réception européenne du traité ‘Du sublime' au XVI et au XVII' siècle." Revue d'H istoire Littéraire de la France 86: 33-51.

Goyet, Francis. 1991-1992. “Le pseudo-sublime de Longin.” Études Littéraires 243: 105-19.

Graziani, Françoise. 1996. “Le miracle de l'art: le Tasse et la poétique de la meraviglia." Revue des Études I taliennes 42 (1/2): 117-39.

Guardiani, Francesco. 1986. "Torquato Tasso. L'umanità della rivelazionenel M ondo creato." C ritica Letteraria 51 (14): 211-24.

Halliwell, Stephen, Donald Russell, and Doreen C. Innes, eds. 1995. A ristotle: P oetics. Longinus: On the Sublime. Demetrius: On Style. Cambridge (MA): Harvard University Press.

Halliwell, Stephen. 2012. Between Ecstasy and Truth. Interpretations of Greek P oetics from H omer to L onginus. Oxford: Oxford University Press.

Hardie, Philip. 2009. Lucretian Receptions: History, the Sublime, Knowledge. Cambridge: Cambridge University Press.

Kates, Judith A. 1983. Tasso and Milton: The Problem of Christian Epic. Lewisburg: Bucknell University Press.

Lehtonen, Kelly. 2016. "Peri H ypsous in Translation: The Sublime in SixteenthCentury Epic Theory." Philological Q uarterly 95 (3/ 4): 449-65.

Lehtonen, Kelly. 2019. “The Satanic Subl ime in Paradise L ost: Tasso, Charisma, A bjection." M odern Philology 116 (3): 211-34.

Leo, UIrich. 1954. "Torquato Tasso alle soglie del secentismo." Studi Tassiani 4: 3-17.

Lewalski, Barbara Kiefer. 2003. The Life of John M ilton: A Critical Biography. Revised edition. Oxford: Blackwell.

Lieb, Michael. 1970. The Dialectics of Creation. Patterns of Birth and R egen eration in Paradise Lost. Amherst: University of Massachusetts Press. 
Luparia, Paolo. 1987. “II 'Mondo creato' poema sapienziale.” Giornale Storico della Letteratura Italiana 164 (525): 1-33.

Milton, John. 1953. Complete Prose W orks of John M ilton [CPW ]. 8 vols. Edited by Don M. Wolfe. New Haven and London: YaleUniversity Press.

Milton, John. (1957) 1975. The Christian D octrine. In Complete Poems and M ajor Prose, edited by Merritt Y. Hughes, 900-1020. Indianapolis: The Odyssey Press.

Milton, John. (1674) 1993. Paradise Lost. $2^{\text {nd }}$ ed. Edited by Alastair Fowler. Harlow: Pearson Longman.

Morace, Rosanna. 2016. "N ote sulla genesi e sulla lingua del M ondo creato." In "In te son nulla." Studi sulla poesia sacra di Torquato Tasso, edited by Marco Corradini and Ottavio Ghidini, 111-38. Rome: Storia e letteratura.

Patterson, Annabel M. 1971. "Tasso and Neoplatonism: The Growth of his Epic Theory." Studies in the Renaissance 18: 105-33.

Platt, Peter G. 1992. “'N ot before either known or dreamt of': Francesco Patrizi and the Power of Wonder in Renaissance Poetics." The Review of English Studies 43 (171): 387-94.

Porter, James I. 2016. The Sublime in Antiquity. Cambridge: Cambridge University Press.

Quint, David. 2014. Inside Paradise Lost. Reading the Designs of M ilton's Epic. Princeton and Oxford: Princeton University Press.

Radzinowic, Mary Ann. (1978) 2015. Toward Samson Agonistes. The Growth of M ilton's M ind. Princeton and Oxford: Princeton University Press.

Ramachandran, Ayesha. 2015. The Worldmakers. Global Imagining in Early M odern Europe. Chicago and London: The University of Chicago Press.

Schwartz, Regina M. 1993. Remembering and Repeating. On M ilton's Theology and P oetics. $2^{\text {nd }}$ ed. Chicago and London: Chicago University Press.

Scianatico, Giovanna. 1994. “II poema 'meraviglioso'. Per un'ipotesi sul M ondo creato." In Dall'idillio alla visione. Passaggi della differenza tra Rinascimento e Barocco in area napoletana, edited by Raffaele Girardi, Giovanna Scianatico, Raffaele Cavalluzzi and Pasquale Guaragnella, 6198. Manduria: Piero Lacaita Editore.

Steadman, John M. 1976. Epic and Tragic Structure in Paradise Lost. Chicago and London: The University of Chicago Press.

Sylvester, Joshua. (1605) 1979. The Divine Weeks and W orks of Guillaume de Saluste, Sieur du Bartas. Vol. I. Edited by Susan Snyder. Oxford: Clarendon Press.

Tasso, Torquato. 1875. Prose diverse. Vol . 2. Edited by Cesare Gausti. Florence: Le Monnier. 
Tasso, Torquato. 1959. Prose. vol. 2. Edited by Ettore Mazzali. Milano and Napoli: Ricciardi.

Tasso, Torquato. 1973. D iscourses on the H eroic Poem. Translation with notes by Mariella Cavalchini and Irene Samuel. Oxford: Clarendon Press.

Tasso, Torquato. 1982. Creation of the World. Edited by Joseph Tusiani. Binghamton: Center for M edieval \& Early Renaissance Studies.

Tasso, Torquato. (1607) 2007. II mondo creato. Vols. I.i-ii. Edited by Paolo Luparia. Alessandria: Edizioni dell'Orso.

Teskey, Gordon. 2006. Delirious Milton. The Fate of the Poet in M odernity. Cambridge (MA): Harvard University Press.

How to cite this article:

Montori, Irene. "Representing Creation, Experiencing the Sublime: The Longinian

Tradition in Tasso and Milton." SEDERI 30 (2020): 69-89.

https:/ / doi.org/ 10.34136/ sederi.2020.4

A uthor's contact: irene.montori@fondazione.uniromal.it

Postal address: Department of European, American and Intercultural Studies - Piazzale Aldo Moro 5- 00185 Rome - Italy 



\title{
The romance of Nahum Tate's King Lear
}

\author{
Katherine Romack \\ U niversity of West Florida, U S
}

\begin{abstract}
Nahum Tate's History of King Lear (1681) refigures Shakespeare's natural man on a Hobbesian model in order to make the play legible to Restoration audiences. As a way to mitigate Hobbes's ethically hollow conception of human nature as acquisitive and self-interested, Tate provides his viewers with a compensatory romance. Tate's "unaccommodated Man" is governed by self-interest yet capable of transcendent love (3.3.81). The liberties Tate took with Shakespeare catered to his audience's uneasy assimilation of secular and empirical ideas about what it meant to be human that made Shakespeare's original feel both alien and disturbing. The romanticized human nature offered up in Tate's Lear accounts for the success the play enjoyed well into the nineteenth century. As much as we might give the adaptation the side-eye, we are, in fact, affectively and ethically closer to Tate than we are to Shakespeare.
\end{abstract}

KEYWORDS: King Lear; Nahum Tate; Shakespeare; ethics; Christianity; romance.

\section{El romance del King Learde N ahum Tate*}

RESUMEN : La obra History of King Lear de Nahum Tate (1681) reinterpreta al hombre natural de Shakespeare de acuerdo a un modelo hobbesiano para hacer la obra más aceptable para el público de la Restauración. Para aliviar la concepción hobbesiana de la naturaleza humana como algo codicioso y egoísta, Tate le da a su público un romance compensatorio. El "unaccommodated Man" de Tate está gobernado por el egoísmo y sin embargo es capaz de sentir amor trascendente (3.3.81). Las libertades que Tate se toma con Shakespeare atienden a la asimilación incómoda, por parte de su público, de ideas seculares y empíricas acerca de

\section{0 romance de King Learde $\mathrm{N}$ ahum Tate}

RESUMO: History of King Lear (1681), de Nahum Tate, refaz o homem natural de Shakespeare segundo um modelo hobbesiano, a fim de deixar a peça mais ao gosto do público da Restauração. De maneira a polir a conceção de Hobbes da natureza humana como gananciosa e interessada apenas em si, Tate oferece aos seus espectadores um romance compensatório. O "unaccommodated Man" de Tate é governado pelo interesse próprio, mas é capaz de um amor transcendente (3.3.81). A licença que Tate adota em relação a Shakespeare ajusta-se à assimilação desconfortável que o seu público fez de ideias seculares e empíricas sobre o

*Translation into Spanish by Tamara Pérez-Fernández.

** Translation into Portuguese by Miguel Ramalhete.

(5) ederi 30 (2020): 91-115

https:/ / doi.org/ 10.34136/ sederi.2020.5 
lo que significa ser humano, y que hicieron que el original de Shakespeare fuese percibido como algo extraño e inquietante. La naturaleza humana romantizada que se presenta en el Lear de Tate explica el éxito del que disfrutó la obra hasta bien entrado el siglo XIX. Por mucho que menospreciemos la obra, nosotros estamos, de hecho, más alineados con Tate que con Shakespeare desde el punto de vista afectivo y ético.

PALABRAS CLAVE: King Lear; Nahum Tate; Shakespeare; ética; cristianismo; romance. que significa ser humano, eque fez o original de Shakespeare parecer estranho e perturbador. A natureza humana romantizada apresentada em Lear de Tate explica o sucesso que a peça teve até ao sé culo XIX. Por mais que possamos olhar de lado para esta adaptação, estamos, de facto, afetivamente e eticamente mais alinhados com Tate do que com Shakespeare.

PALAVRAS-CHAVE: King Lear; Nahum Tate; Shakespeare; ética; cristianismo; romance.

"This is simply dreadful," the modern reader might be inclined to react on first encountering Nahum Tate's The $\mathrm{H}$ istory of King Lear (1681). In what George Odell refers to as a "mangling" of the original, Tate transforms Shakespeare's tragedy into romance: Cordelia lives, and Lear is restored to his throne (1966, 54). ${ }^{1}$ An amorous entanglement between Cordelia and Edgar is added-along with a parental obstacle (Lear wants her to marry Burgundy). Tate softens the impact of Lear's response to Cordelia in the love trial, stressing that "the Infirmity of his Age" has "unfixed" his temperament, rendering him "Chol'ric" (1.1.55). Edgar assumes his disguise as Poor Tom to watch over Cordelia. Even the blinding of Gloucester is made meaningful (1.1.227). ${ }^{2}$ As Gloucester impeaches the cruelty of Cornwall, Regan, and Gonerill by revealing his blindness to the "pittying Crowd," the thought that his blindness has served the king's cause comforts him: "well have I sold my eyes, if the event prove happy for the injured King" (3.5.86; 4.2.12-13). Tate omits the Fool along with France (eliminating thethorny question of why an English

\footnotetext{
1 "Late eighteenth and early nineteenth-century critics could not have enough fun with the wind and the suns and the spheres that had nothing else to do but wait for Cordelia to ascend the throne" (Odell, 1966, 56).

${ }^{2}$ References to Tate's Lear are drawn from Sandra Clark's Shakespeare M ade Fit: Restoration Adaptations of Shakespeare (1997). I will use the Norton edition of Shakespeare's complete works edited by Stephen Greenblatt throughout, which provides both folio and quarto texts of Lear. Parentheticals with $\mathrm{F}$ or $\mathrm{Q}$ designate Shakespeare's Lear, those with no designation Tate's. For a summary of Tate's strategic use of both editions of Lear see Massai (2000). References to other plays and poems by Shakespeare will be drawn from the Greenblatt edition as well and cited by title in the parentheticals.
} 
King would provide a foreign power with a third of his kingdom). Tate's Bastard is a stock libertine rapist with an insatiable appetite for women, power, and luxury. ${ }^{3}$

What happened to society between Shakespeare and Tate to engender such a Lear? The liberties Tate took with Shakespeare catered to his audience's uneasy assimilation of secular and empirical ideas about what it meant to be human that rendered the Christian morality animating the original play obscure. This made Shakespeare's original feel both alien and disturbing to audiences and critics alike. Tate's conversion of Edmund into a Hobbesian libertine, his addition of a second love trial, and his elimination of the Fool all reflect a reformulation of the relationship between religion and the self, one that necessitates the elevation of amatory love to moral imperative. Tate's radically reconceived vision of "unaccommodated $M$ an" reflects the gradual seventeenth-century transformation of the human subject into an autonomous agent and an attendant transfer of moral authority from God to man (3.3.81). The ethical landscape of Tate's Lear is essentially Hobbesian. The Bastard, for example, is obviously a stock caricature of the vainglorious self-seeker, governed by desire for self-preservation and material increase. Tate also presents more nuanced exemplars of the rational mastery of the passions in the service of the common good. Characters like Cordelia and Edgar model this type of restraint. These characters reflect a broader cultural dissonance, torn, as they are, between passion and self interest in an environment where ethics is increasingly subjective and relativized. Tate resolves this conflict by converting Lear into romance. As much as we might find the romanticized Lear off-putting today, the twenty-first century is, in some crucial respects, more closely aligned with Tate than with Shakespeare.

\section{"The stars in secret influence comment"}

In 1985 William Elton published a famously salutary refutation of optimistic, Christian readings of Shakespeare's Lear. He was correct to assert that empirical evidence of Christian providentialism, redemption, and deliverance is nowhere to be found in Shakespeare's tragedy. Elton's claims about the "skeptical disintegration of

\footnotetext{
${ }^{3}$ For a discussion of the politics of rape in the play see Depledge (2014).
} 
providential belief" and the "breakdown of the medieval analogical relation" are, however, overstated $(1988,335)$. The hand of God is at work in the tragedy, even if it isn't always easy to detect. The stars, that "in secret influence comment" on the action of the play can only be regarded as indifferent from a modern epistemological perspective ("Sonnet 15," 4). Although it's true that the medieval idea of the corporate body was already coming under pressure, Shakespeare's audiences still had one foot in a medieval world that figured the creation as organically whole and unified by a Christian Logos. The self was still primarily regarded as planted by God into a landed or fixed order of things, and obedience to God and stewardship of the creation were still regarded as the chief social and ethical mandates. God is hidden, but nonetheless present in the uncannily sympathetic landscape that so evidently responds to Lear's internal turmoil. Numerous Christian references and images pepper the play-from Lear's initial ex nihilo nihil fit to the remarkable inversion of the Pietà at the close of the play. Every honest word and action in the play, especially Cordelia's "nothings" and Kent's service, are premised upon a devotion to the Christian God. Unfashionable as this claim might be, the play is deeply fideist. Perhaps it is, in part, our own distrust of logocentrism that prevents us from detecting the Christian impulses of the play.

For one thing, it hardly seems likely that a playwright seriously experimenting in agnostic skepticism would-to the horror of critics like Sidney, Jonson, and Puttenham-immediately turn his energies to the manifestly providential romance Pericles (ca. 1607-1608). Trevor Nunn, who directed an adaptation of the romance in 2016, draws the following comparison between Pericles and Lear:

At the end of many of Shakespeare's tragedies there is some sense
that a new order can begin. Attheend of Lear thereis no such feeling.
The Gods have been appealed to countless times, in countless awful
situations and in Lear they never hear, never respond. They never
makeanything better. It's almost astonishing that thenext thing that
he does is a play that has got a fairytale ingredient, a story that
culminates in the kinds of coincidence or luck that you can only
describeas miraculous. (Nunn 2016)

The proximate composition of the plays suggests that Pericles is something of a romantic restorative to Lear and, as such, essentially conservative. As Gower announces in the opening lines of Pericles, "The purchase [of the play is] to make men glorious, | Et bonum quo 
antiquas, eo melius" [the more ancient a good, the better] ("Chorus," 910). Pericles resounds with Marian imagery, Papist symbols, and Catholic rites. The play echoes both medieval hagiography and miracle plays about Mary Magdalene and Tobit (see Fel perin 2000). It is an especially interesting play to compare to Lear, not least because we have a rare piece of documentary evidence that reveals something of the religious reception of these plays in Shakespeare's England. In 1609 , a group of Catholic players, who had been performing under the authority of Sir Richard Chomley were charged before the Star Chamber with staging "a seditious play of Catholic purport, at York's house, Gowthwaite Hall in Nidderdale" (Sisson 1942, 135). Yet in addition to the miracle play about St. Christopher that led to the arrest of the company, the troupe's repertoire included both Pericles and King Lear (see Wood 2006, 441-50). That Shakespeare should follow Lear up with a romance bearing so striking a resemblance to a miracle play is, contra Nunn, unsurprising. ${ }^{4}$ Considering Lear alongside Pericles reveals an overarching generic pattern of suffering and redemption that is a residue of the collision between classical romance and the peregrinations of spiritual biography. As Marina Scordilis Brownlee writes of a thirteenth-century Spanish adaptation of the Latin romance of A polonius:

The antique matter of the original Apolonius biography has thus been radically transformed-serving an extra-textual truth in its Spanish reworking, the extra-textual truth of Christian doctrine. Fortune - the arbitrary, unjust force which tampers with human life in a thoroughly unpredictable manner-has been replaced by God, the arbiter of justice who rewards good and punishes evil accordingly. The multiple adventures - calculated only to provide suspenseful entertainment in the antique text-have acquired a transcendent meaning in the Spanish romance. $(1983,173)^{5}$

Lear's descent from king to wandering exile begins to look a lot more like a test of faith. Wemight wonder why Shakespeare chose to violate the tradition of romance and happy endings that dominate his medieval and Renaissance source texts. It may well be that

\footnotetext{
${ }^{4}$ In as much as Catholics and Protestants shared the same Christian history, the question of whether the play is Catholic or Protestant is immaterial to my argument here.

${ }^{5}$ For other investigations of the structural continuity between hagiography and dramatic romance see Deyermond (1975), Walsh (1977), Brownlee (1983), and Womack (1999).
} 
Shakespeare's tragic subversion of the story of Lear allowed him to interrogate the grounds of love and obligation in a way that the more romantic versions of the Lear story forestalled. ${ }^{6}$ The play is, after all, centrally concerned with putting love on trial.

The exchange between Edmund, Gloucester, and Edgar about the meaning of the eclipses in the second scene, presents us with a stark juxtaposition of the competing views of human nature presented by Shakespeare's play. Gloucester exhibits a belief in the metaphysical power of eclipses that "portend no good to us. Though the wisdom of nature can reason it thus and thus, yet nature finds itself scourged by the sequent effects" (F1.2.95-98). In response, Edmund labels him "credulous" (F1.2.156). The bastard exhibits a purely secular understanding of nature and therefore dismisses Gloucester's honest investment in astrological signs as "foolish."

This is the excellent foppery of the world: that when we are sick in fortune - often the surfeits of our own behavior-we make guilty of our disasters the sun, the moon, and the stars, as if we were villains by necessity, fools by heavenly compulsion, knaves, thieves, and treachers, by spherical predominance, drunkards, liars, and adulterers by an enforced obedience of planetary influence, and all that we are evil in, by a divine thrusting on. An admirable evasion of whoremaster man, to lay his goatish disposition to the charge of a star! (F1.2.108-15)

The thespian Edmund immediately dons the garb of a "sectary astronomical" in his subsequent interaction with Edgar. As his brother enters, Edmund quips, "and on's cue out he comes, like the catastrophe of the old comedy; mine is villainous melancholy, with a sigh like them of Bedlam. - $\mathrm{O}$, these eclipses do portend these divisions" (Q1.2.119-20). Edmund is a purely intellectual creature, relying on the human capacity for the utilization of instruments (in this instance, performance and rhetoric) to manipulate a world he conceives as a resource to be exploited. Yet, even as he mocks his father's belief in an astrological portent-one that is, of course,

\footnotetext{
${ }^{6}$ Shakespeare's most immediate source text, the anonymous True Chronicle $\mathrm{H}$ istory of King Leir (1594), for example, was deeply ideological, deploying pastoral romance didactically to generate support for Elizabeth's foreign policy: "Spectators (and Elizabeth) were offered an idyllic and optimistic view of the conflict, while the menacing figure of a foreign invader was turned into a chivalric hero only willing to save his beloved's father from utter ruin. The succession issue is not even mentioned, and the foreign monarch soon returns to his kingdom" (Álvarez-Recio 2012, 664).
} 
resoundingly vindicated by the play's action-he unwittingly reveals that the genesis of his own villainy was wrought by "a divine thrusting on":

My father compounded with my mother under the Dragon's tail and my nativity was under Ursa Major, so that it follows I am rough and lecherous. Fut! I should have been that I am had the mai denliest star in the firmament twinkled on my bastardy. (F1.2.116-21)

In 1946, Johnstone Parr observed that, having been born under the sign of Ursa Major, "Edmund's career shows him to be in large measure the living embodiment of astral influences exerted by the malignant constellation" (Parr 1946, 183). A sign governed by the conjunction of Mars and Venus, Ursa Major portended depravity, deception, cruelty, fornication, adultery, incest-the very "machinations, hollowness, treachery, and all ruinous disorders" Gloucester attributes to the eclipses (F1.2.103-104). These qualities are identical to the "rough and lecherous" constitution Edmund denies even as he cannot escape it (F1.2.101-103). Edmund is damned, incapable of transforming his erotic and political cupidity into caritas. As he lies dying, he makes a final effort to contravene this nature: "Some good I mean to do, I Despite of mine own nature" (F5.3.21819). Yet even this attempt to escape the moral disposition thrust upon him is destined to fail.

Tate foregrounds the Bastard's "Thou Nature" soliloquy, placing it at the opening of the first act. This deflects attention from Lear's love trial and foregrounds Edmund's transformation from a Machiavel to a Hobbesian villain. Tate cuts all mention of Edmund's nativity, and with it, anything that establishes his evil as unfree or Satanically "thrust on." The Bastard is "cynical, treacherous, lustful and cruel, judging the rightness of a cause by its success, and recognizing no power beyond his own strength" (Black 1967b, 380). He is a self-styled libertine, a conspicuous consumer and dissipated lover of opulence, a creature of self-interest pitting his craftiness against the "right of Law," the only obstacle to the unconstrained pursuit of desire in the world Tate creates (1.1.12-13). Edmund's evil is neither intrinsic nor metaphysical, it is volitional-he chooses self-interest over the common good, and this choice is marked as depraved. His libidinous desire for possession is boundless. In Shakespeare, Edmund is also driven by eros, but this is understood in the Renaissance sense, as the fallen product of an original sin that, at best, inspired a longing for 
God and, at worst, became idolatrously fixated on temporal objects of desire. Critics frequently remark that Shakespeare's Edmund is Hobbesean. This is, of course, an anachronism. The central difference between Edmund and Tate's Bastard is that eros in the Restoration was coming to be understood as natural, inevitable, and morally neutral. This subtle shift in emphasis had titanic ethical implications. As eros is transformed into a valueneutral passion, there is no impetus to sublimate desire from self-interest to a more ethically acceptable form.

The ontology governing Shakespeare's Lear declined in direct proportion to the rise of Hobbesian nominalism and a mechanical and reified post-Cartesian view of the self. Human sense perception was itself radically altered. New gods supplanted the old. Tate wrote on the cusp of the Deist revolution that would reject the superstitions of both revealed religion and church dogma in favor of an outlook in which God's laws are reformulated as intrinsic to nature and rationally discernable. This God is the D eus A bsconditus that Elton misattributes to Shakespeare's L ear. ${ }^{7}$ As Simon May remarks, "It took the genius of Baruch Spinoza to place man so indissolubly in nature that the very idea of transcending it [...] would make no sense" (May 2011,143 ). Ideas of good and evil persist, but they are less fixed and universal and more relative and contingent, a matter of customary agreement, held together by law, and invested with a telos by a remote, though rationally demonstrable, Creator. The human subject that had traditionally understood itself as existing in a metonymic relation to the order of things surrendered to thereign of thesovereign subject. ${ }^{8}$ The modern subject is free and active, exercising subjective dominion over a reified world by rationally weighing the probability of empirical outcomes. This subject interprets the world through the

\footnotetext{
${ }^{7}$ The contributions to this idea of God available to Tate, beyond Hobbes's, include Herbert's D e veritate (first published in England in 1633) and D e religions (1645) as well as Spinoza's Tractatus theologico-politicus (1670). Charles Blount's Anima mundi (1679), G reat is D iana of the Ephesians (1680), and The T wo First Books of Philostratus (1680) were all published in the years immediately preceding the appearance of Tate's Lear.

${ }^{8}$ This subject is "the free, unconstrained author of meaning and action, the origin of history. Unified, knowing, and autonomous, the human being seeks a political system which guarantees freedom of choice. Western liberal democracy, freely chosen, and thus evidently the unconstrained expression of human nature, was born in the seventeenth century with the emergence of the individual and the victory of constitutionalism in the consecutive English revolutions of the 1640s and 1688" (Belsey 1985, 8).
} 
lens of the cost-benefit analysis required to navigate a landscape of competing interests. There is an intensified need to scrutinize the self and others for evidence of motivation. The complex choreography of manners that emerges in this period is only one product of an intensified need to scrutinize the self and others. As N orbert Elias has it, 'In order to be 'courteous' by the standard of civilité, one is to some extent obliged to observe, to look about oneself and pay attention to people and their motives" $(1978,78)$. The ethical constitution or "credit" of the subject could presumably be identified by a careful observation of patterns of social conduct. This emphasis on behavioral observation goes hand-in-hand with the period's widespread fascination with probability.

Tate took A ristotle's dictum about dramatic probability seriously. ${ }^{9}$ He eliminates the loose ends and ambiguities of Shakespeare's play with a surgical precision that renders the action credible and divests the play of its sublime mystery. ${ }^{10}$ Tate's idea of the probable was, unlike Aristotle's or Shakespeare's, conditioned by the idea of the rational calculus. ${ }^{11}$ Mathematical models of probability held out the promise of revealing the mechanics of the natural world, and these were accompanied by new quantitative and utilitarian models of social and moral probability. Tate's Bastard is evil because he is an untrustworthy cheat who refuses to subordinate his immediate selfinterest to the rules of consent that preserve the common good. What this "good" might consist of, however, is rather amorphous and difficult to pin down. The Bastard's evil, his turn away from the laws

\footnotetext{
9 "A poet's object is not to tell what actually happened but what could and would happen either probably or inevitably" (A ristotle, 35 [1451a.36-38]).

10 "Why does Edgar adopt such an uncomfortablealias instead of simply running away? why do both heand Kent retain their disguises after the need for them has passed? why are Lear and Gloucester left straying about rather than being delivered to the French camp? what happens to the fool? who is in command of the French army? Tate's reforms answer or abolish almost all of these questions, and so recover the dramatis personae as active subjects within a syntax of intelligible cause and effect" (Womack 2002, 99).

${ }^{11}$ It is no coincidence that the period that favored Tate's Lear at the expense of Shakespeare's corresponds exactly to the period Lorraine Daston and others have identified with the evolution of Classical probability theory into a reasonable calculus. "Between Roughly 1650 and 1840 mathematicians of the caliber of Blaise Pascal, Jacob Bernoulli, and Pierre Simon Laplace labored over a model of rational decision, action and belief under conditions of uncertainty. Almost all of the problems they addressed were couched in these terms" (Daston 1998, xi). See also Patay (1984).
} 
of the social contract, is marked as an unnatural volition. As he announces, twelvelines in, "Of law I will oppose a bastard's cunning" (1.1.12). Significantly, Shakespeare's Edmund makes no specific reference to law, as the informal communal idea of the Christian bond had not yet been supplanted by the legislative and contractual enforcement of social responsibility. In Shakespeare's age, social relations, even in the marketplace, were still "conceived of in explicitly moral terms, and not those of amoral self-interest" (Muldrew 1993, 177). As the seventeenth century wore on, debt litigation exploded with the erosion of the communitarian Christian ethics that had once guaranteed early modern credit. ${ }^{12}$ Especially distressing to the Restoration subject is the possibility that the laws of nature, and of the market, cannot be unlocked and harnessed by reason, and that the world is essentially amoral, chaotic and meaningless. This universe is the one that critics, from the Restoration on, have erroneously assigned to Shakespeare's Lear. Tate's return to romance attempts to rectify the perceived moral vacuity of Shakespeare's original.

\section{"There's beggary in the love that can be reckoned"}

Describing the royalist romance of the 1650s, Victoria Kahn explains that it depicts "a world of passion and interest" where "honor" and "nobility" serve as a thin veil for "factional self-interest and selfaggrandizement" $(2002,627){ }^{13}$ The writers of the new romance

\footnotetext{
${ }^{12} \mathrm{~N}$ or were people, Muldrew continues, "in any way concerned with interpreting profit as a social good likely to lead to increased future wealth, in the manner of utilitarian ethics" $(1993,177)$.

${ }^{13}$ Christine Lee provides an excellent survey of the problems that inhere in the critical deployment of the term "romance." "Much of what we today call Renaissance 'romance' was, in its own day, a genre without a name-if, in fact, the authors of the new modes of fiction believed they worked with a common genre at all" $(2014,287)$. Like Lee, I am interested in the way that the formalization of "romance" in the 1620s and 30s shifts the generic emphasis of the term from "male heroics," chivalric wandering, and the miraculous to "imagination and the passions" restrained by neoclassical unity and new understandings of probability $(2014,299)$. I am also, like James Grantham Turner, less interested in the way that romance contributed to the rise of the novel than I am in the distinction al ready being drawn in the restoration between the Old Romance and New Romance that is captured perfectly in Turner's epigraph drawn from Pierre-Daniel Huett's 1672 Treatise of Romances: “As our Manners and Peopleare refin'd, Romances also hold pace with us, and by the same degrees arrive to perfection. Giants, Dragons and Enchanted Castles, which made so much noise in
} 
regarded the rational control of self-interest and the restraint of the passions as essential to cultural stability. Yet, they also "resist the complete demystification of the passions - the reduction of the passions to varieties of self-interest" (Kahn 2002, 627). Passionatelove, in particular, becomes synonymous with virtue. In the Restoration and eighteenth century, the deferred and ennobling object of the romantic quest is progressively restricted to the object of amorous love. ${ }^{14}$ The relative moral poverty of virtues such as honor and nobility in the new romance is bound up with the domestication of the romantic object. By the beginning of the twentieth century, romance would become even more strictly conflated with amorous love. Tate regarded his greatest improvement of Shakespeare to be the insertion of a "Love betwixt Edgar and Cordelia," characterizing this as an "Expedient to rectifie what was wanting in the Regularity and Probability of the Tale" ("Dedication"). This "Expedient" makes credible Cordelia's refusal to provide words of love to Lear and explains the intensity of his response to this withholding. It also gives "Countenance to Edgar's Disguise, making that a generous Design that was before a poor Shift to save his Life" and heightens "The Distress of the Story" ("Dedication"). Lear's love trial in Tate is prefaced by an exchange between Edgar and Cordelia in which they lament Cordelia's impending betrothal to Burgundy:

EDGAR Cordelia, royal Fair, turn yet once more,

And e're successfull Burgundy receive

The treasure of thy Beauties from the King,

E're happy Burgundy for ever fold Thee,

Cast back one pitying Look on wretched Edgar.

CORDELIA Alas what wou'd the wretched Edgar with

The more Unfortunate Cordelia;

Who in obedience to a Father's will

Flys from her Edgar's Arms to Burgundy's? (1.1.56-64)

This exchange conditions the meaning of the love trial to come (which Tate lifts almost verbatim from the original). Cordelia's

Romances of former times, are now no longer heard of" (Turner 2012, 58). Complicating this is the fact that theatrical romance has a history distinct from that of poetry or prose.

${ }^{14}$ Patricia Parker characterizes romance as "a form that simultaneously quests for and postpones a particular end, objective, or object" $(1979,4)$. Barbara Fuchs, following Parker, reads romance as a "textual strategy" rather than a collection of generic markers $(2004,9)$. 
communication of an incalculable love, duty, and obligation invested with metaphysical and traditional import is reduced to bargaining and rhetorical maneuvering. Tate's stress is on Cordelia's revulsion at the thought of the "loath'd Embraces" of Burgundy (1.1.95). In the lines that follow, Lear's response is made probable in two ways. His choleric disposition is attributable to age, and he is predictably outraged that Cordelia's fondness for the "Rebel Edgar" has sparked her dissent.

LEAR And goes thy Heart with this?

'Tis said that I am Chol'rick, judge me Gods, Is there not cause? now Minion I perceive

The Truth of what has been suggested to Us, Thy Fondness for the Rebel Son of G loster, False to his Father, as Thou art to my Hopes. (1.1.16-121)

Most modern interpretations of Lear share Tate's investment in Cordelia's motives and intentions. In 1811, Coleridge attributed her refusal to produce a love boast to "some little faulty admixture of pride and sullenness," while W.W. Lloyd characterized Cordelia as "provoking" the tragic outcome of the play by "mistaking the point of moral support where service was most wanted" (Coleridge 1874, 192; Lloyd 1889, 444-45). Shellee Hendricks attributes to Cordelia an incestuous "resistance to exogamy, a resistance which implies a desire to remain in part with King Lear" $(1999,52)$. William Dodd more positively evaluates Cordelia as "a character struggling to possess her dialogic right of access to the world of personhood" (1999, 490). Richard Halpern represents Cordelia as a creature motivated by the intrigues of court. He asserts that she "has more than a little in common with the play's villainous characters," representing her response to her father as calculated, even "cruel" (1991, 248-49). In Halpern's reading, Cordelia "poses a fundamental challenge to [Lear's] authority" and in so doing "releases an aristocratic game of challenge and counter challenge" (1991, 249-50). ${ }^{15}$

The subjective agency that motivates Cordelia in Tate cannot be assumed of Shakespeare's heroine. Autonomy and its derivative discourses of right, the goodness of freedom, self-sufficiency, and selfgovernance do not pertain to a culture in which all are subject.

15 These are only a few examples that are close-to-hand as a comprehensive enumeration would be impossible. One would be hard put to find a critical appraisal of Cordelia that isn't organized around the question of her volition. 
Cordelia's silences in the original do not conceal hidden motives in need of excavation or reveal a naively conceived and abstract "impotent goodness" (Halpern 1991, 248). In the love-trial, Shakespeare dramatizes the force of the qualitative bonds governed by Christian obligation. Cordelia's expression of duty is meaningful only with reference to a subjectivity understood as metonymically related to a corporate unity authored by and subject to God.

CORDELIA Good my lord,

You have begot me, bred me, loved me.

I return those duties back as are right fit-

Obey you, love you, and most honour you.

Why have my sisters husbands if they say

They love you all? Haply, when I shall wed

That lord whose hand must take my plight shall carry

Half my love with him, half my care and duty.

Sure, I shall never marry like my sisters,

To love my father all. (Q1.84-93)

Cordelia's duty is unintelligible outside a context that binds social obligation to obedience. For instance, it is incomprehensible to the transactional attitude to others and the world that is demanded by the economy of primitive accumulation. Lear's tragic flaw is that he fails to understand that love is not a quantity to be accumulated, that "there's beggary in the love that can be reckon'd" (Antony and Cleopatra, 1.1.15). When Cordelia gives half her love away, this will in no way diminish her lovefor her father, for unlike exchange-value her love is unquantifiable. Terence Hawkes has noted that Shakespeare's love test draws on a longstanding pun on two senses of love dating back to the fourteenth and fifteenth centuries, when the Old English lofian (to appraise, value, or state the price of) and lufian (to love) became homonyms. The pun is found in both Wace and Holinshed (Hawkes 1959, 178). Cordelia's "nothings" express her lufian, her faith in the unquantifiableidea of the Christian bond. This idea of the bond was the glue of an economy of informal reciprocal obligation that predated modern credit and contract, and that structured nearly every aspect of social life in the early modern period (see Muldrew 1993, 2001). This idea of obligation was steadily eroded by the selffashioning and desacralized ionotropic displays of secular power that characterized the Elizabethan and Jacobean courts (see Rust 2006). James I's totalizing form of absolutism, which eliminated entirely "the reciprocal duties of dominus and homo," is clearly an important target 
of Shakespeare's play (quoted in Halpern 1991, 220). Like James I, Lear is oblivious to the reciprocity and stewardship informing the Christian bond-they both reduce kingship to a one-sided property relation (1991, 221-23).

Shakespeare regularly wrote of the inadequacy of words to praise the beloved, and commonly presented the poet as a debtor incapable of paying the usurer. Hesimilarly al ways grants genetic reproduction an intrinsic value that poetic production is incapable of capturing. Cordelia's "Love" is a sublime "nothing," inaudible to a father invested in "reckoning" her love. As Hawkes elaborates, "Cordelia's refusal of his world of quantity and calculation had been met by Lear's exasperated parody of theological debate, 'Nothing will come of nothing: speak again.' But human beings never simply 'speak'. Any utterance is always complicated, particularly in a pre-literate society, by the body" (1959, 52). The body's "unignorable presence supplies a living and modifying context" for the nothings spoken by Cordelia (1959, 52). Lear's investment in words of love at the play's opening gives way to an ability to hear the nothings of his poor, hanged fool at the end: "Cordelia, Cordelia: stay a little | Ha? What is't thou sayst? Her voice was ever soft" (F.5.3.246). His final words in the Folio edition suggest that at the moment of his death he sees his daughter's lips parting to speak: “Do you see this? Look on her. Look, Her lips. Look there, look there" (F5.3.285-86). In the quarto edition, this rapprochement is followed by Kent's final words, "I have a journey, sir, shortly to go: | My master calls, and I must not say no" (Q24. 31516).

Love in Shakespeare was still evaluated in terms of its relationship to a transcendent God or fallen temporality. When desire works as a motor for transcendence it is redemptive; when it is idolatrous it is Satanic. In contrast, Restoration literature placed an increased premium on a temporal love that muddies the ethics of affect. Not only did erotic love change from "a potentially tragic to potentially desirable condition," with the rise of such things as companionate marriage, it was well on its way to "achieving what once only divine lovewas thought capable of: to be our ultimate source of meaning and happiness, and of power over suffering and disappointment" (Gorer 1989, 8; May 2011, 1). The royally-sponsored theatre is peopled by characters who openly embrace self-interest while aspiring to the interiority and sincerity of the modern individual. The concealment of 
the self-interest that pervades Restoration amatory discourse is a slippery endeavor that can only be accomplished through an abstraction or, rather a de-referentialization of love's object. Tate's restoration reduction of Cordelia to a woman wrangling to get her man occurs at the same historical moment that freethinking, sincerity, and interiority were being assigned to individual subjects.

Tate's Hobbesian romance exemplifies this transvaluation of eros. Hobbes understood all human behavior to be a product of a perpetual war between self-preservation and power adjudicated by reason. However, reason for Hobbes was not, as it had been for Descartes, conceived of as immaterial substance emanating from a mind conceived of as synonymous with the soul. Instead, "The very rationality of the calculus is defined by the capacity of the passion to guide the imagination and identify the means for reaching the desired objective" (Coli 2006, 75). Reason is refigured "as a system of signs, logical operations, laws and conventions" that are purely immanentthe product of the movement generated by the conflict between warring passions (Coli 2006, 80). The problem with Hobbes's social contract is that there is no eternal guarantee of allegiance to it, nothing to ensure that the impulses generated by individual memories of fear and pain would be enough to hold in check the pleasurable will to power that always threatens to tear the community apart. A stronger incentivization of fealty to the social contract-a "new affective basis for political obligation"-was needed (Kahn 2002, 627). ${ }^{16}$

Love, in Tate's Lear, cements the social order. This love, however, is qualitatively different from the eros, agape, and philia of the Renaissance. It is simultaneously secular and transcendent-either "true" (because free and untainted by interest) or non-existent. After Burgundy rejects Cordelia, she proceeds to throw Edgar into confusion by pretending to reject his love. In thelovetrial orchestrated by Cordelia, passionate love must be certified as untainted by "Int'rest." Edgar must prove his disinterested sincerity before she will grant him her love:

This Baseness of th' ignoble Burgundy

Draws just suspicion on the Race of Men,

${ }^{16}$ The general attempt to navigate the antipodal secular relationship between rational constraint and passion would be formalized seventy years later with Baumgarten's aesthetics. 
His Love was Int'rest, so may E dgar's be

And He but with more Complement dissemble;

If so, I shall oblige him by Denying:

But if his Love be fixt, such Constant flame

As warms our Breasts, if such I find his Passion,

My Heart as gratefull to his Truth shall be,

And Cold Cordelia prove as Kind as He. (1.1.227-33)

Edgar's love must remain disinterested if it is to be freely chosen. Cordelia's faith in the bright flame of freely-chosen romantic love invests it with a spiritual quality capable of suturing over the illogic of figuring disinterested interest as an ethical good.

\section{"This great stage of fools"}

One of the most important revelations about human nature in Shakespeare's Lear is that it is essentially foolish: "When we are born, we cry that we are come | To this great stage of fools" (F4.5.172-73). Fools represent the messiness and ambiguity of the human condition, all of the contradictory attributes of human experience that defy rational explanation and sometimes touch the transcendent. The Fool's resistance to categorical determination is grounded in his liminal, unpropertied status. The Fool, the wandering Lear, and Poor Tom are all creatures who have relinquished their possessions, down to their very self-possession. The progress from identity to liminality requires a complete divestiture of the self and its interests. The deployments of the term "slave" in Lear are interesting in this regard, as they so frequently align slavery not with a lack of self-possession, but with violations of Christian obligation. Oswald is, for example, repeatedly labeled a slave by honest Kent because "Such smiling rogues as these, | Like rats, oft bite the holy cords a-twain | Which are too intrinse t'unloose" (F2.2.67-68). Kent, by contrast, has "ever honour'd [Lear] as my king, I Loved as my father, as my master follow'd, | As my great patron thought on in my prayers" (F1.1.13840). Kent's love of Lear is grounded in a positive ethos of obedience and subjection.

Shakespeare's play was written during the Union Controversy, and James's selective use of feudal precedent to promote a species of absolutism that foregrounded feudal property law and downplayed theological justifications for monarchical power-in effect, converting the power of kingship "from a political into a property relation" (1991, 
221). The landscape of Shakespeare's Lear is thoroughly absolutist on a Stuart model. Lear comes to understand that reducing monarchy to property alone renders it vulnerable. "Lear carves up his patrimony in one bold if misguided stroke, whereas James fritters his away through conspicuous consumption and the inflation of honors," but the result is much the same (231). Lear's abdication initiates the reduction of "an armigerous nobility into a class welding only consumption signs" (242). ${ }^{17}$ Once Lear gives his property away, his authority evaporates. However, this detachment from property grants him (and Edgar, who experiences a similar dispossession) a special access to the metaphysical space occupied by the Fool. To be foolish is to embrace the mysterious inscrutability of human existence.

The Fool is the paragon of unaccommodated man. A figure of paradox and irresolvable contradiction, theFool in Lear is worldly but innocent, young but wise, facile but profound-even male but female. ${ }^{18}$ As we have seen, there is no place for superstitious fools like Gloucester in the self-interested economy of human naturelaid out by Tate. The many references to fools and foolishness that pepper Shakespeare's original (more than 120 altogether) are reduced by Tate to seven. The Fool is simply eradicated from the play, resulting in a Lear whose madness is transformed from a profound philosophical interrogation of the ground of value, truth, and ethics to the solipsistic sickness and infirmity of an increasingly self-interested culture. What Shakespeare depicted as Lear's de-centering through a dispossession that occasions an encounter with the unnamable, is, for Tate, simply a question of mental illness, a "real" versus "pretended" madness

\footnotetext{
${ }^{17}$ One thing that is surprising about Tate's adaptation is just how little it addresses the political content of Shakespeare's play. His play was published in the midst of the Exclusion Crisis yet expresses very littleinterest in engaging the politics of the day. This probably had something to do with the reception of his Richard II. But it was also because signs of kingship in Tate's day had al ready been thoroughly voided of spiritual substance. For examinations of the adaptation that situate Tate's Lear within the Exclusion Crisis, seeHardman (2000), Depledge(2014) and Bender (2016). Other studies of the influence of the Exclusion Crisis on Tate include Wikander (1986), Viator (1988), Johnson (1995), and Álvarez-Recio (2009).

${ }^{18}$ There is a rising critical consensus that the close association between the characters of Cordelia and the Fool was physically accentuated on the stage by the same youthful actor playing each of these characters. See A brams (1985) and Green (1972). For other appraisals of the fool in Lear see Empson (1949), Goldsmith (1955), Strong (1961), and Seiden (1979).
} 
("Dedication"). ${ }^{19}$ Lear is, from the opening of Tate's play, "with wild starts of passion hourly seiz'd" (1.1.51-55). His madness is, in a word, pathological-he is marked as feeble and mentally unstable from the beginning. If Tatedraws a sharp distinction between Lear's "real" and the king's "pretended" madness, Shakespeare elides them in the figure of Edgar who does go out of his head as he relinquishes everything, including his noble name, becoming, apart from the fool, the least "accommodated" of any character in Lear: "Edgar I nothing am" (F2.2.178). It is divestiture that brings Lear closest to the truth of the human condition-that we possess nothing, not even ourselves: "Behold, the heaven and the heaven of heavens is the Lord's thy God, the earth also, with all that therein is" (Deuteronomy 10:14). We are not the owners but the stewards of creation. It is at this moment of recognition that Lear labels Poor Tom a "noble Philosopher" and asks for his companionship (4.4.154), evoking the philia at the heart of philosophy's central existential question. As Sylviane Agacinski observes in "La question de l'autre," the possibility of asking the question of being is al ready bound up with an obligation to others. "If the philosophical question is a shared one, philosophy must already be home to a certain P hilia" (54). It was something likethis conjunction of being with a love grounded in dispossession that Shakespeare had in mind when composing Lear.

\section{The Tatefied Lear}

The cadre of editors and theatre critics that proliferated in the Restoration almost universally took issue with Shakespeare's killing of Cordelia (as well as with the insinuation that Kent would follow Lear to the grave). In his "Remarks on the Plays of Shakespeare" (1710), Charles Gildon expressed a strong preference for Tate's Lear, asserting that the destruction of Cordelia and Kent in Shakespeare's original was so random and unjust that it rendered its audiences too disgusted to achieve the level of "pity and fear" that would allow them to experience the play as tragedy (Gildon 1710, 406). A year later

\footnotetext{
${ }^{19}$ What, Shakespeare seems to ask, is the relationship between the diverse, messy, and transient world of human experience and the transcendent but objective good that grants meaning to this inchoate experience? As it is impossibleto verbally articulate the force animating Christian love, Lear seems to ask: might not the metaphysical nature of obligation be better approached through the performative experience?
} 
Joseph Addison, one of the few holdouts for Shakespeare, protested that the play "lost half its Beauty" when it was forced to conform to this "chymerical Notion of Poetical Justice" $(1739,156)$. As chimerical as many of the critical charges laid against Shakespeare's Lear might have been (the notoriously erratic critical appeals to the dramatic unities are a case in point) Tate's play prevailed. With the exception of occasional purists like Addison, audiences and critics alike found themselves applauding Tate's thoroughgoing "rectification of Lear" ("Dedication"). Even Samuel Johnson added his "general suffrage" to the new Lear-although he grudgingly concurred with Addison that the original was "deservedly celebrated among the dramas of Shakespeare" $(1765,158)$. Johnson believed that the play's ostensible lack of moral probability (the chief criticism of Shakespeare's play from the Restoration on) was a result of "the barbarity and ignorance of the age to which this story is referred" $(1765,158)$. Behind the slew of vague and inchoate seventeenth and eighteenth-century denunciations of Shakespeare's Lear, what the critics are actually conveying is that Shakespeare's supposed elision of the transcendent laws governing man's existence in the tragedy evoked in them the same species of dread that seized Pascal when he contemplated the possibility of eternal silence. ${ }^{20}$ Johnson characterized the play as "unendurable" because the Christian ethics assumed by Shakespeare's Lear were no longer operative (171-72). Such discomfort with Lear could only appear in a culture that had lost the ability to intuit the divine authority suffusing theinscrutablenothings of Shakespeare's play.

Tate himself characterized Shakespeare's play as primitive, "a heap of jewels, unstrung and unpolished" ("Dedication"). ${ }^{21}$ He felt no compunction about bringing Shakespeare up to date and into line with the taste of Restoration audiences, pillaging Shakespeare's play

\footnotetext{
20 "When I consider the short duration of my life, swallowed up in the eternity before and after, the little space which I fill, and even can see, engulfed in the infinite immensity of spaces of which I am ignorant, and which know me not, I am frightened, and am astonished at being here rather than there; for there is no reason why hererather than there, why now rather than then. Who has put me here? By whose order and direction have this place and time been al lotted to me? [...] The eternal silence of these infinite spaces frightens me" (Pascal 1958, 61).

${ }^{21}$ Labeling Shakespeare "unpolished" was, importantly, not a mistake made by Johnson, who therefore found Shakespeare's play all the more disturbing, even, as Frank Kermode puts it, "wounding" $(2005,171)$.
} 
without any misgivings about "so bold a Change" ("Dedication"). What Tate could only describe as a chaotic assemblage of "extravagant Nature (I know not how else to express it)" required him to take the "heap" that was Shakespeare's Lear and polish it into a form that a Restoration audience would find natural and appealing ("Dedication"). This refinement required an aesthetic reformulation of human nature, as Shakespeare had presented it, and a liberation of the unfree subject that constituted Shakespeare's idea of "unaccommodated man." He wagered that making everything in the play plausible to his audiences by presenting characters and outcomes that spectators could find believable would guarantee its success.

And so it did. The Tatefied Lear would dominate the stage at the expense of Shakespeare's well into the nineteenth century. Borrowings from Tate, in fact, continue to render performances of the play more palatable today. ${ }^{22}$ By the time Tate adapted the play sometime around 1681, the "poor, bare, forked, animal" contemplated in Shakespeare's Lear became, for most, less legibleand, consequently, more troubling (F3.4.96-97). Tate was no philosopher: he was a playwright, and his only concern was that the play be "well Receiv'd by my Audience" ("Dedication"). He steered a wide course around the hard existential questions posed by the tragedy- his focus was on the here and now of this world. The neoclassical reformation of the theatre and its reformed romance appealed to a spectator who was no longer

prepared to take therisks of terror and revelation implicit in tragedy. He wished to shudder briefly or dream at ease. When coming from thestreet into the playhouse, hewas not leaving thereal for the more real (as does any man who is willing to encounter the imaginings of Aeschylus, Shakespeare or Racine); he was moving from the fierce

\footnotetext{
22 The process of returning Shakespeare's original to the stage can be seen as early as Garrick's 1756 production which restored much of the original language to the play but left Tate's innovations with plot intact. In the period between Garrick and Macready's thoroughgoing return of Shakespeare's Lear to the stage in 1838, Tate's version continued to dominate the stage. For extended discussions of the adaptation history of Lear see Spencer (1963), and Black (1967a). For an account of the myriad ways in which Tate's adaptation continues to shape contemporary productions of Lear, see Adler (1985).
} 
solicitations of current history and economic purpose into therepose of illusion. (Steiner 1968, 116) ${ }^{23}$

The culture to which Tate's play appealed was one that Pascal violently denounced:

we condemn those who live without thought of the ultimate end of life, who let themsel ves beguided by their own inclinations and their own pleasures without reflection and without concern, and, as if they could annihilate eternity by turning away their thought from it, think only of making themselves happy for the moment. (Pascal 1958, 59)

We are more attracted to than disturbed by what remains of Shakespeare's original, perhaps, because the nihilism dreaded by Tate's audience has become second nature to us. What we find most aesthetically unappetizing about Tate's Lear is the play's romantic innovations; yet, our current reverence for Lear, as well as our distaste for the conservative amatory economy of Tate's adaptation, are each premised upon a refusal to acknowledge the timeworn ethical system that governed Shakespeare's tragedy. Our investment in the moral neutrality of the passions, in fact, goes far beyond Tate's. Instead of converting amorous love into a virtue, we posit choice itself as an unquestionable good. As much as we might try to rationalize our own instinctive subjective volunteerism, it is quite incompatible with any ethical schema. Tate, at least, can be credited with attempting to supply Lear with an ethics.

\section{References}

A brams, Richard. 1985. "The Double Casting of Cordelia and the King's Fool:

A Theatrical View." Texas Studies in Literature and Language 27 (4): 354-68.

Addison, Joseph, and Richard Steele. 1739. The Spectator. $12^{\text {th }}$ ed. London: Printed for J. and R. Tonson and S. Draper.

Adler, Doris. 1985. “The Half-Life of Tate in King Lear." The Kenyon Review 7 (3): 52-56.

${ }^{23}$ Renaissanceaudiences "delighted in clowns, in comic interludes, and in theacrobatics and brutality of physical action. The Elizabethan spectator had strong nerves and demanded that they be played upon" (Steiner 1968, 21). This is just the sort of thing that Tate excises from his adaptation. 
Agacinski, Sylviane. 2004. "The Question of the Other (Critique of Egocentrism)." In French Women Philosophers, A Contemporary Reader, edited by Christina Howells, 39-55. London: Routledge.

Álvarez-Recio, Leticia. 2009. “Nahum Tate's The History of King Richard the Second (1681): Politics and Censorship during the Exclusion Crisis." Restoration and Eighteenth-Century Theatre Research 24 (1): 17-30.

Álvarez-Recio, Leticia. 2012. "Romance, Politics and Money: The French Cause in The TrueChronicleH istory of King Leir." English Studies 93 (6): 65267.

A ristotle. 1932. A ristotle: The Poetics. Longinus: On the Sublime. Demetrius: On Style. Edited by W. Hamilton Fyfe. London: W. Heinemann.

Belsey, Catherine. 1985. The Subject of Tragedy: Identity and Difference in Renaissance D rama. London: Methuen.

Bender, Ashley. 2016. "Rhetorical Bodies in Nahum Tate's King Lear and Ingratitude of a Commonw ealth." Papers on Language and Literature 52 (1): 6390.

Black, James. 1967a. "A n Augustan Stage History: Nahum Tate's King Lear." Restoration and $18^{\text {th }}$ Century Theatre Research 6 (1): 36-54.

Black, James. 1967b. "The Influence of Hobbes on Nahum Tate's King Lear." Studies in English Literature 7 (3): 377-85.

Blount, Charles. 1679. A nima mundi, or, An historical narration of the opinions of the ancients concerning man's soul after this life according to unenlight[e]ned nature. London: Printed by Will. Cademan.

Blount, Charles. 1680a. Great is D iana of the Ephesians, or, The original of idolatry together with the politick institution of the gentiles sacrifices. London.

Blount, Charles. 1680b. The T wo First Books of Philostratus concerning the L ife of A pollonius Tyaneus written originally in Greek, and now published in English: together with philological notes upon each chapter. London: Printed for Nathaniel Thompson.

Brownlee, Marina Scordilis. 1983. "Writing and Scripture in the Libro De A pol onio: The Conflation of Hagiography and Romance." H ispanic R eview 51 (2): 159-74.

Coleridge, Samuel Taylor. 1874. Shakespeare, Ben Jonson, Beaumont and Fletcher: $\mathrm{N}$ otes and Lectures. Edited by Edward Howell. Liverpool: Edward Howell.

Coli, Daniela. 2006. “Hobbes's Revolution." In Politics and the Passions, 15001850, edited by Victoria Kahn, Neil Saccamano, and Daniela Coli, 75-92. Princeton: Princeton University Press.

Daston, Lorraine. 1998. Classical Probability in the Enlightenment. Princeton: Princeton University Press.

Depledge, Emma. 2014. “The Politics of Rape in Nahum Tate's The H istory of King L ear, 1681." In Renaissance Shakespeare: Shakespear eR enaissances, edited 
by Martin Procházka, Michael Dobson, Andreas Höfele, and Hanna Scolnicov, 317-24. Newark: University of Delaware Press.

Deyermond, Alan D. 1975. "The Lost Genre of Medieval Spanish Literature." H ispanic Review 43: 231-59.

Dodd, William. 1999. “Impossible Worlds: What Happens in King Lear, Act 1 , Scene 1." Shakespeare Q uarterly 50 (4): 477-507.

Eagleton, Terry. 1990. Thel deology of the A esthetic. Oxford: Basil Blackwell.

Elias, Norbert. 1978. The Civilizing Process. Vol. 1: The History of M anners. Translated by Edmund Jephcott. N ew York: Urizen Books.

Elton, William R. 1988. King Lear and the Gods. Lexington: University of Kentucky Press.

Empson, William. 1949. "Fool in Lear." The Sewanee R eview 57 (2): 177-214.

Felperin, Howard. 2000. “'This great mirade': Pericles.” In Pericles: Critical Essays, edited by David Skeele, 114-32. New York: Garland.

Fuchs, Barbara. 2004. Romance: A Critical Idiom. New York: Routledge.

Gildon, Charles. 1710. "Remarks on the Plays of Shakespeare." In The W orks of M r. W illiam Shakespear. V olume the Seventh, edited by Nicholas Rowe, 257-444. London; Printed for E. Curll and E. Sanger.

Goldsmith, Oscar James. 1955. Wise Fools in Shakespeare. East Lansing: Michigan State University Press.

Gorer, Geoffrey. 1989. “On Falling in Love.” In Eros, A gapeand Philia: Readings in the Philosophy of Love, edited by Alan Sobel, 6-11. New York: Paragon House.

Green, Lawrence D. 1972. “'Where's my fool?'-Some Consequences of the Omission of theFool in Tate's Lear." Studies in English Literature 12 (2): 25974.

Greenblatt, Stephen. 1980. Renaissance Self-Fashioning: From M ore to Shakespeare. Chicago: University of Chicago Press.

Halpern, Richard. 1991. The Poetics of Primitive Accumulation: English Renaissance Culture and the Genealogy of Capital. Ithaca: Cornell University Press.

Hardman, C. B. 2000. “'Our Drooping Country Now Erects Her Head': Nahum Tate's History of King Lear." The M odern Language Review 95 (4): 913-23.

Hawkes, Terence. 1959. “'Love' in King Lear.” The Review of English Studies 10 (38): 178-81.

Hawkes, Terence, ed. 1995. William Shakespeare, King Lear. Plymouth, U.K.: Northcote House.

Hendricks, Shellee. 1999. "The Curiosity of Nations": King Lear and the Incest Prohibition. PhD diss. McGill University. 
Romack

Herbert of Cherbury, Edward. 1633. D everitate, prout distinguitur a revelatione, a verisimili, a possibili, et a falso. London.

Herbert of Cherbury, Edward. 1645. De causis errorum una cum tractatu de religione laici, et appendice ad sacerdotes. London.

Johnson, Odai. 1995. “Empty Houses: The Suppression of Tate's Richard II." Theatre Journal 47 (4): 503-16.

Johnson, Samuel. 1765. TheW orks of W illiam Shakespeare. Vol. 6. London: J. and R. Tonson et al.

Kahn, Victoria. 2002. "Reinventing Romance, or the Surprising Effects of Sympathy." Renaissance Q uarterly 55 (2): 625-61.

Kermode, Frank. 2005. Shakespeare, Spenser, D onne. London: Routledge.

Lee, Christine S. 2014. "The Meanings of Romance: Rethinking Early Modern Fiction." M odern Philology 112 (2): 287-311.

Lloyd, William Watkiss. 1889. Critical Essays on the Plays of Shakespeare. London: George Bell and Sons.

Massai, Sonia. 2000. "Nahum Tate's Revision of Shakespeare's King Lears." Studies in English Literature 40 (3): 435-50.

May, Simon. 2011. Love: A H istory. New Haven: Yale University Press.

Muldrew, Craig. 1993. "Interpreting the Market: The Ethics of Credit and Community Relations in Early Modern England." Social History 18 (2): 163-83.

Muldrew, Craig. 2001. “'Hard food for Midas': Cash and its Social Value in Early Modern England." Past \& Present 170: 78-120.

Nunn, Trevor. 2016. “Theatre for a New Audience's PERICLES, directed by Trevor N unn." https:/ / www.youtube.com/ watch?v=7N 6RvGMbRQ

Odell, George C. D. (1920) 1966. Shakespeare From Betterton to Irving. Vol. 1. New York: Dover.

Parr, Johnstone 1946. "Edmund's Nativity in King Lear." The Shakespeare A ssociation Bulletin 21 (4): 181-85.

Pascal, Blaise. 1958. Pascal's Pensées with an Introduction by T. S. Eliot. Translated by W. F. Trotter. New York: E.P. Dutton.

Parker, Patricia A. 1979. Inescapable Romance: Studies in the Poetics of a M ode. Princeton: Princeton University Press.

Patay, Douglas Lane. 1984. Probability and Literary Form: Philosophic Theory and Literary Practice in the A ugustan Age. Cambridge: Cambridge University Press.

Rust, Jennifer. 2006. "'Image of Idolatryes': Iconotropy and the Theo-Political Body in The Faerie Q ueene." Religion \& Literature 38 (3): 137-55.

Seiden, Melvin. 1979. "The Fool and Edmund: Kin and Kind." Studies in English Literature 19 (2): 197-214. 
Shakespeare, William. (1608, 1623) 2008. King Lear. In The N orton A nthology of Shakespeare, $9^{\text {th }}$ edition, edited by Stephen Greenblatt et al., 2336-67. N ew York: W.W. Norton.

Sisson, Charles J. 1942. "Shakespeare's Quartos as Prompt Copies. With some Account of Chomley's Players and a N ew Shakespeare Allusion." R eview of English Studies 18 (70): 129-43.

Spencer, Christopher. 1963. "A Word for Tate's King Lear." Studies in English Literature 3 (2): 241-51.

Spinoza, Baruch. 1670.Tractatus theologico-politicus. Hamburg: Henricus Künraht.

Steiner, George. 1968. The D eath of Tragedy. New York: Alfred A. Knopf.

Tate, Nahum. (1681) 1997. The H istory of King Lear. In Shakespeare M ade Fit: Restoration Adaptations of Shakespeare, edited by Sandra Clark, 291-373. London: J. M. Dent.

Tierney-Hynes, Rebecca. 2012. N ovel M inds: P hilosophy and Romance Readers, 1680-1740. New York: Palgrave Macmillan.

Turner, James Grantham. 2012. “'Romance' and the Novel in Restoration England." The Review of English Studies 63 (258): 58-85.

Viator, Timothy J. 1988. "Nahum Tate's Richard II." Theatre N otebook 42 (3): 109-17.

Walsh, John K. 1977. "The Chivalric Dragon: Hagiographic Parallels in Early Spanish Romances." Bulletin of H ispanic Studies (54): 189-98.

Wikander, Matthew H. 1986. "The Spitted Infant: Scenic Emblem and Exclusionist Politics in Restoration Adaptations of Shakespeare." Shakespeare Q uarterly 37 (3): 340-58.

Womack, Peter. 1999. "Shakespeare and the Sea of Stories." The Journal of M edieval and Early M odern Studies 29 (1): 169-87.

Womack, Peter. 2002. "Secularizing King Lear: Shakespeare, Tate, and the Sacred." Shakespeare Survey 55: 96-105.

Wood, Ian. 2006. "Pericles and the Simpsons." Leeds Studies in English 37: 44150.

\footnotetext{
How to cite this article:

Romack, Katherine. “The Romance of Nahum Tate's King Lear." SED ERI 30 (2020): 91-115.

https:/ / doi.org/ 10.34136/ sederi.2020.5

A uthor's contact: kromack@uwf.edu

Postal address: Department of English - University of West Florida -11000 University

Pkwy - Pensacola, FL 32514 - USA 



\title{
Truth and wonder in Richard Head's geographical fictions*
}

\author{
Sonia Villegas López \\ U niversidad de H uelva, Spain
}

\begin{abstract}
In line with the method prescribed by members of the Royal Society for natural history and travel writing, Richard Head explored the limits of verisimilitude associated with geographical discourse in his three fictions The Floating I sland (1673), The W estern W onder (1674) and 0 -Brazile (1675). In them he argues in favor of the existence of the mysterious Brazile island and uses the factual discourse of the travel diarist to present a semi-mythical place whose very notion stretches the limits of believability. In line with recent critical interpretations of late seventeenth-century fiction as deceptive, and setting the reading of Head's narrations in connection with other types of travel writing, I argue that Head's fictions are a means of testing the readers' gullibility at a time when the status of prose, both fictional and non-fictional, is subject to debate.
\end{abstract}

KEYWORDS: Richard Head; Brazile island; truth and wonder; deception in fiction.

Verdad y maravilla en las ficciones geográficas de Richard Head

RESUMEN : En consonancia con el método prescrito por los miembros de la Royal Society para la historia natural y la escritura de viajes, Richard Head explora los límites de la verosimilitud asociada al discurso geográfico en sus tres obras de ficción TheFloating Island (1673), TheW estern W onder (1674) y 0 -Brazile (1675). En ellas se muestra a favor de la existencia de la misteriosa isla de Braziley utiliza el discurso fáctico del viajero para presentar un lugar semi-mítico cuya noción va más allá de los límites de lo verosímil. Acorde con interpretaciones críticas recientes sobre la ficción de finales del

\section{Verdade e M aravilha nas Ficções G eográficas de Richard H ead ${ }^{* *}$}

RESUMO: Seguindo o método prescrito por membros da Royal Society para a história natural e a escrita de viagens, Richard Head explorou os limites de verossimilhança associada ao discurso geográfico em três ficções suas: The Floating Island (1673), The W estern W onder (1674) e 0 -Brazile (1675). Nelas, Head argumenta a favor da existência da misteriosa ilha de Brazile e usa o discurso factual do diarista de viagem para apresentar um lugar semi-mítico cuja própria ideia força os limites da credibilidade. Em consonância com interpretações críticas recentes da ficção do final do século XVII como enga-

\footnotetext{
*This article is one of the results of the research project "Early N ovel in English, 16601700: Database and Textual Editing" (ENEID), financed by MINECO (Ref. FFI201782728-P).
}

** Translation into Portuguese by Miguel Ramalhete.

$$
\text { (5) ederi } 30 \text { (2020): 117-37 }
$$


siglo XVII como engañosa, y situando la lectura de las narraciones de Head en relación con otros tipos de narrativa de viajes de la época, sostengo que las ficciones deH ead son un modo de poner a prueba la credulidad de los lectores en un momento en que el estatus de la prosa, tanto ficcional como no ficcional, está sujeta a debate.

PALABRAS CLAVE: Richard Head; Isla de Brazile; verdad y maravilla; ficción y engaño. nosa, e relacionando a leitura das narrações de Head com outros tipos de escrita de viagem, argumento que as ficções de Head são um meio de testar a credulidade dos leitores num momento em que o estatuto da prosa, tanto ficcional como não ficcional, está sujeito a debate.

PALAVRAS-ChAVE: Richard Head; Ilha de Brazile; verdade e maravilha; engano em ficção.

In the mid-1670s, the Irish hack writer Richard Head published three related geographical fictions on the existence and discovery of an enchanted island-Brazeel, Brazile, or Brasil, in the different versions-situated on the western coast of Ireland. ${ }^{1}$ Under the guise of different fictional personalities, The Floating Island (1673), The W estern W onder (1674), and O-Brazeel, the Inchanted Island (1675) have been all attributed to him. They share their description of a wonderful island, recorded on ancient and more recent maps, which had mysteriously disappeared in the author's time. By exploring the contours of truth and wonder, I argue that he is consciously playing with the limits of believability in fiction, training his readers in distinguishing true from false accounts, by discerning between reliable and unreliable methods of narrative truth-telling. In so doing, Head is inspired by true travel diaries and takes elements from other previous travel fictions, also anticipating later imaginary journeys. My argument is that in the three texts under inspection, Head blurs the boundaries between credibility and deception, instructing his audience in the art of reading skeptically. In the pages that follow, I will briefly refer to the general notions of truth and wonder at work in seventeenth-century philosophical and scientific contexts, to focus more extensively on the ways in which the emerging critical discourse on prose fiction incorporates them, particularly in relation to forms of travel writing. Finally, I will concentrate on the representation and combination of true and wonderful elements in Head's Brazile

\footnotetext{
${ }^{1}$ I reproduce in the article the particular spelling employed in each text, and choose "Brazile" to refer to the island in more general terms. As Robert Fuson claims, thereare more than twenty forms of spelling the name, five of which are of Gaelic origin (1995, 44).
} 
narratives which speak of the hybrid and still unstable nature of late seventeenth-century methods of literary and scientific inquiry.

\section{Truth, wonder and deception in late seventeenth-century fiction}

The interrelated notions of truth and wonder were invariably associated in the Renaissance with the discourses of religion, history and natural philosophy. In A Social History of Truth (1994), Steven Shapin was concerned with "truth-generating practices" (1994, Xxi) at work in the seventeenth century, which he identified with a gentlemanly society, most specifically with institutions of knowledge like the Royal Society, and with the work of some of its members like Robert Boyle. The assumption went that knowledge as truth was in the hands of trustful individuals alone, whereas lying and deception were clear symptoms of moral and social disorder (1994, 9-10). The importance of distinguishing truth from lies was also a priority at a time in which a number of political-cum-religious plots seemed to menace the stability of the state. ${ }^{2}$

On the other hand, wonder has been considered the origin of philosophical inquiry and discourse (Sell 2006, 5). In the sixteenth and seventeenth centuries, it was basically related to any encounter with what caused surprise or astonishment, and was identified with miraculous events that could be found in nature, as Marsilio Ficino contended (Blum \& Blum 2011, 1-2); with the unpredictability of man's behavior, in Pico della Mirandola's view in Oration on the Dignity of $M$ an (1486); or even with the capacity to distinguish true from false religions, using the related principles of belief and authority, in line with Tomasso Campanella's A theism Conquered (1606-1607). In the age of empiricism, wonder was, nonetheless, reassessed as problematic but al so as what fostered the very processes of knowledge-making (Das 2016, 21). Wonder was also appropriated by travel writers, who marveled at the new places and objects they encountered and wanted to elicit similar responses in their readers. In

\footnotetext{
${ }^{2}$ More than fifteen pamphlets and allegorical works on the figure of the informer were published between 1660 and the mid-1680s. Most of them presented the figure of the informer as a controversial character and an unreliable source, especially because they were paid in return for their services. On this figure, see John Dunton's allegorical text The Informer's D oom (1683).
} 
this context, wonder was at the service of the literary market, as it often raised the interest and curiosity of an audience which was developing a taste for the foreign.

Critics of early prose fiction (Davis 1983; McKeon 1987; Hunter 1990) have often engaged with the distinction between truth and wonder in relation to the epistemological systems of romance and novel, following in many respects Ian Watt's developmental theory (Salzman 1999,295). Lennard Davis has proposed a Foucauldian reading of the novel as discourse concerned with "ruptures and transformations" that help us interpret the social and contextual relations that explain the evolution of the genre $(1983,9)$. He claims that romances should enforce verisimilitude, meant not as a technique of formal realism, but only as a means "to defictionalize the work to an acceptable threshold of credibility" (Davis 1983, 31). He argues further that the fact and fiction diatribe is at the heart of the news/ novels discourse, and that the apparent contradictions that define it constitute the very foundation of the genre. Final interpretations are left in the readers' hands, who were most probably unable to say whether what they read was true or not (Davis 1983, 70).

One of the emblematic examples of the characteristic claims to truth in early fiction is Behn's Preface to O roonoko, or the $\mathrm{H}$ istory of the Royal Slave (1688), where the author makes a claim in favor of the true nature of her story, set in two far-away lands, alien to the experience of most English readers. Behn's strategy of suggesting that she has been eye-witness of most narrated events, or that shehad received the story from the protagonist himself, is a ploy to excuse the romantic and improbable details in her tale, pressing her audience to accept its believability (Behn 1994, 6). Alongside seemingly probable events, Behn includes elements of wonder, directly related to the world of romance. Cases in point would be Behn's marvelling at the natural wonders and curiosities that could be found in the colony $(1994,47)$, or the Indians' astonishment at the customs and the aspect of westerners like Behn and her brother, which they referred to as "Tepœeme" or "numberless wonders" (1994, 53).

Michael McKeon has argued that romance was often associated with a broad notion of "history" in the course of the seventeenth century, whereas the novel was generally related to the world of "news," an umbrella term that alluded to very different kinds of material. Behind the variety of labels applied to fiction at the time, the 
ongoing debate was (and still is) how to tell the truth in narrative (M cKeon 1987, 27). Progressively, romances as "histories" began to be differentiated from "true histories," the name often used to refer to shorter specimens of fiction whose plots drew closer to the readers' worlds and everyday experience. However, as seventeenth-century texts demonstrate, a pattern of double reversal in relation to both epistemology and ideology can be applied to romances and novels. A complex epistemological transformation needed to take place before "the novel" was accepted as a distinct category representing prose fiction in the eighteenth century $(1987,27)$. This transformation was gradual and can be traced in the prefaces and dedicatory epistles to the fictional texts themselves, in which their authors address the truth versus falsehood issue mostly in association with the worlds of romance and the novel. ${ }^{3}$

In both genres, though, the aim of prose fiction writers was to gain the reader's credibility (Tieje 1913, 213). Percy Adams has also referred to the credibility of gullible or candid seventeenth- and eighteenth-century readers, who were keen to consume fictional narratives which were either truth-like or passed for truth $(1983,88)$. In a similar vein, Kate Loveman argues that late seventeenth-century authors solicited "candid" readers, with whom to createa relationship of mutual respect and honesty, as their prefaces and dedicatory epistles demonstrate $(2008,19)$. The reader's task, however, was to discern truth from fiction, reading the texts skeptically: "Readers not only suspected that the true meaning of a work had been disguised but also that the writer had a devious, possibly malicious, design upon his audience" (Loveman 2008, 20). Thus, writer and reader negotiated the limits of believability, the role of the writer being to convince the reader of the basic truths of his story and the reader's part to suspect the evidence of truth. Readers dedicated themselves

\footnotetext{
${ }^{3}$ In the epistle to the reader in The Secret $\mathrm{H}$ istory of Q ueen Z arah and the Z arazians (1705), Delarivier Manley distinguishes between romances-or "Iong-winded Performances" whose "Likeness" is "so little managed"-and "little Pieces" which are "much more agreeable to the Brisk and Impetuous Humour of the English" (1705, iv). In the preface to Incognita, or Love and D uty Reconcil'd (1692), William Congreve argues that romances are full of "miraculous Contingencies and impossible Performances" and that they "elevate and surprise the Reader into a giddy Delight," whereas novels are "Intrigues in Practice [...], such which not being so distant from our Belief bring al so the Pleasure nearer us," concluding that "Romances give more of Wonder, Novels more Delight" (1692, A4). In spite of appearances, there are not many differences between the two forms, as the contradictory titles given to novels demonstrate.
} 
on many occasions to "read against the grain," encouraged by the intellectual forays of science and natural philosophy, by religious skepticism (especially of Catholics) and by the alleged testimonies of truth at the court of law. The topic was popular in works like Meric Casaubon's of Credulity and Incredulity in things $\mathrm{N}$ atural, Civil, and D ivine (1668), where the author warned readers against the danger of falling into "unadvised belief, or unbelief," frequently seen as sources of superstition and atheism. In Casaubon's account, the wonder of fiction became associated with the faith of religion, that could not be granted through sensorial apprehension- "not discernible with bodily eyes" (1668, Sig B, 2)-but through rational discernment and "Divine revelation." To read texts skeptically became an extended practice which even reached the new social sphere of the coffee-house and which distinguished good from bad citizens, as Dunton argued in The Informer's D oom (1683), leaving to his readers' "candid View" (Sig A 2) the ability to discern between friends and enemies of thestate.

Not only in the titles of the lives, letters, and journals, but most importantly in the appearance, techniques and reliability of the stories, writers wanted to achieve the credit that historians had been granted in earlier times (Adams 1983, 89). Different kinds of material-and Restoration printed material was indeed variedelicited different responses and allegiances to truth. Gerd Bayer explores this issue, concluding that "questions of representation" were vivid and true to seventeenth-century readers, and that apparently they shared expectations about the degree of truth different types of texts displayed $(2016,190)$. In spite of the Royal Society's promotion of travel accounts which relied on direct experience and individual observation, Adams has noted that the form of travel writing was associated with the shadow of lie and deceit. More often than in other fictional types, they were required to authenticate facts for a growing audience of avid readers who wanted to know what exotic and mysterious places had in store $(1983,94)$.

\section{Seventeenth-century travel narratives: Factual fictions}

The seventeenth century was rife with stories of imaginary journeys and utopian narratives. Encouraged by the voyages of discovery and geographic exploration, and by the travel writings and diaries that illustrated them and supported their credibility, authors wrote tales 
of adventure, sometimes based on true accounts and journeys and others on purely fictional ones. The purpose of the former works was basically informativeand didactic, as they were meant to reinforce the English character in contrast to the rest of the world. According to LeslieB. Cormack, "with theincremental accumulation of information about Europe, patterns of national behavior and trading relations could emerge. Descriptions of the four corners of the world confirmed English sentiments of superiority and otherness" (1991, 650). These "real" narratives, which spurred the thirst for exploration, as well as for nationalistic feeling and for the knowledge of the Other, promoted colonial exploitation and found a growing number of fictional counterparts, in which authors followed very closely the same methods of description and inductive knowledge as found in true travel accounts. Other exemplars of fictional travel writing are at the heart of Richard Head's texts, like Sir John Mandeville's The V oyages and Travels of Sir John $M$ andeville Knight, first published in the late fifteenth century but newly edited in 1657, Francis Bacon's N ew A talantis, re-edited in 1658, or Henry Neville's The Isle of Pines, published in 1668, and its sequel The Hairy-Giants in 1671. Head's fictions, however, are closer to the branch of chorography than to general geography, due to their interest in the local. His nativel reland is behind his Brazile narratives, and London, his city of adoption, is the real location in his allegorical piece The Floating Island. Head's chorographical fictions were "aimed at the armchair traveler and island-bound country gentleman rather than at the practical navigator or merchant" (Cormack 1991, 654), in contrast to real travel diaries.

In Salzman's view, the late seventeenth-century imaginary journey contained a greater narrative interest than the merely utopian, displaying in many cases an important political and allegorical content. However, the voyage imaginaire inevitably included some utopian reminiscences, and the influences of real travel writing and imaginary journeys were mutual. While the two narrative forms coexisted, truth and lies combined in tales which attracted the readers' interest in new lands, their fauna and flora, and their people and organization. These exotic new territories kindled the imagination of an audience that found in these exotic voyages a form of escapism. ${ }^{4}$

${ }^{4}$ Purely fictional travel narratives coincide with other true travel accounts and geographies, propelled by the new explorations and settlements in other parts of the 
Thediscovery of new lands fueled theinterest of the Royal Society, which promoted methods of scientific inquiry based on reports on correspondence as well as on travelers' experiments and anecdotes (Carey 1997, 271). Members of the Society like Boyle even instructed them on how to make their observations of foreign lands (1997, 272). At the same time, these journeys and the travel writings that recorded them, titillated the imagination of writers who told stories about how other lands were sometimes inhabited by strange and monstrous beings. 5 To illustrate this "narrative" interest in geographical explorations, I will briefly mention Margaret Cavendish's The Blazing W orld. Though not a member of the Society, Cavendish showed her scientific and literary interests in its work, by appending her philosophical observations to her utopian tale. She claimed that The Blazing W orld was entirely the product of her imagination, and that it comprised three different forms: the first part romancical, the second part philosophical and thethird part fantastical (Cavendish 1992, 124). These three elements can bealso found in different degrees in Richard Head's Brazile narratives.

Travel accounts kindled the curiosity of scientists and general readers because they proved that "the course of knowledge was radically open to suggestion" (Carey 1997, 276). In fact, natural philosophers accepted the smooth transition from travel to travel literature, as Daniel Carey suggests, "because not every item observed in travel could be delivered for inspection" (1997, 279). Travel narratives of all kinds, therefore, shared a number of common generic features, like the presence of a first-person voice, or of second-hand accounts, describing experiences recorded or memorized in the course of travel, the references to real time coordinates and to a historical context, as well as a wealth of detail. Seventeenth-century travel narratives came gradually to accommodate truth by following the empirical method of knowledge. The writers navigated between the plausible, the imaginary and sometimes the historical, ascertaining truth by developing a still imprecise narrative method. Precisely,

globe, like John Ogilby's A frica (1670) or Gabriel de Foigny's A N ew Discovery of Terra Incognita A ustralis (1693).

${ }^{5}$ Philosophical tracts and imaginary journeys, like those by Giordano Bruno or Francis Bacon, became a matter of controversy from political and religious perspectives (Matytsin 2013, 361-64). All had their own views about thechanging situation of human beings in the universe, as well as about the interrelation of fancy and scientific works with the revealed truths of religion (Cressy 2006, 962). 
McKeon selects Richard Head's Brazile fictions as models for the demystification of historicizing travel narratives from the perspective of extreme skepticism (1987, 111ff.). Head is skeptical of the association of truth with travel narratives and creates travel tales that are representative of the hybrid status granted to travel writing as well as illustrative of the changing nature of prose fiction at the time. Similarly, following the practice of the Royal Society of accepting the existence of monsters and oddities of nature in the travel accounts, Head makes of his texts "oddities" in their combination of truths and lies.

\section{Truth and wonder in Richard Head's fiction}

The son of an Irish protestant preacher, Richard Head left his native country for France and then England, where part of his mother's family lived (Katanka 1975, 6; The English Rogue, 1665, Sig B4v-B5). He would return to Ireland, where he wrote his Jonsonian comedy $\mathrm{H}$ ic et U bique, or the Humours of Dublin, printed in England in 1663 and including a dedicatory epistle to the Duke of M onmouth. ${ }^{6} \mathrm{H}$ is comedy relied on autobiographical data (Katanka 1975, 35) and presented characters who went bankrupt. Their allusive names-Hope-well, Contriver, Trustall and Bank-rupt-remind us of the universe of his own creation in The Floating Island. In 1664, the first edition of The English Rogue saw the light, published by Henry Marsh, and other editions with new parts followed in the coming years. This work in particular has often been read autobiographically, and Meriton Latroon's ominous life has been interpreted as part of the author's own experience. Head was also the author of some miscellaneous writing, including a historical poem on the Anglo-Dutch wars of 1665-1667 at the height of the conflict, The Red-Sea (1666), a book of prophecies, The Life and D eath of M other Shipton (1667), and the three chosen travel narratives.

Only a few spare facts about Head's eventful life are known, as he sometimes appeared and other times disappeared accosted by debts, in a similar fashion to the mysterious Brazile island. Head moved from England to Ireland, to find his death at sea, drowning off the Isle

\footnotetext{
${ }^{6}$ In Act I, Scene 3 in this play, Contriver, a citizen of London, wished to be sent on an expedition to find Obrazeele to avoid his present fears $(1663,8)$. The island is thus situated by Head in the realm of the improbable and utopia.
} 
of Wight in 1686. Together with some spare autobiographical references, these works portray Head's preference for realistic detail mixed with the fictive and the mysterious. This odd combination of truth and wonder is present most significantly in The Life and D eath of $M$ other Shipton. After commending the historical qualities of his improbable piece, the author adds in a Postcript to this work: "Courteous Reader, let me desire thee Candidly to pass over some seemingly Impossibilities in the first sheet, (allowing the Author Licentia Poetica in her description and someActions performed in her Minority); and only to weigh the more serious parts of her Prophecies." Head is committed in these early works to the representation of truth in fiction, that he takes to the limits of believability.

Between 1673 and 1675, Richard Head wrote three short travel narratives, though none of them was expressly signed by him, probably a strategy to induce his audience to believe that what they were reading was true. ${ }^{7}$ Their attribution is unanimous nowadays, endorsed by ESTC, and suggested by the many interrelated references that connect them to other works in Head's production. The Floating Island, published by one Franck Careless, "one of the Discoverers," is about Captain Robert Owe-much, a member of the Bankrupt Society, and his voyage and sighting of Scoti Moria, or "Summer Island," in the course of an allegorical journey through several London scenes which reproduce some well-known sanctuaries for debtors. A board a fleet of three ships, The Paynaught, the Excuse, and the Least-in-Sight, the expedition finds Scoti Moria, situated in the Thame-Isis gulf and hidden from view in winter time (1673, Sig C2, 13). ${ }^{8}$ In The W estern W onder, the first-person voice of the traveler is anonymous, whereas 0 -Brazile, or the Inchanted Island is a long letter signed by one William Hamilton in Londonderry for his cousin in London, dated March 14, 1674. In line with the former texts, Hamilton's letter describes OBrazile as a place associated with legend and hearsay, but now subject to a "wonderful Dis-Inchantment." 9 The recurrence of the same place

\footnotetext{
${ }^{7}$ Donald Johnson considers 0 -Brazile, or the Inchanted Island not one of Head's works, but a real letter (1999, 117-19) and offers an extensive description of the text.

${ }^{8}$ Mythical accounts of the island of Hy-Brazil agree on the fact that it only appeared once every seven years, a symbolic number in several cultures (Johnson 1999, 124).

${ }^{9}$ Only a couple of years after the publication of O-Brazile, William Winstanley, Head's first biographer, also mentions the island in his book Poor Robin's V ision (1677), where
} 
in the three narratives and the accumulation of similar details in different textual accounts-an allegorical voyage, a travel narrative, and a letter-seem to reinforce the believability of the stories.

Head's accounts of the Brazile island are based on seemingly real evidence. The first documentary proof of a voyage to discover it comes from 1480, when a Bristol expedition set out in search of this mysterious place (Fuson 1995, 43). This enigmatic spot had been reproduced in Portolan charts much earlier, around the 1330s, and it continued to appear in maps till the nineteenth century $(1995,46)$. In popular Irish accounts, this mysterious island is variously called "the submarine country," "isle of life," and "land of talents" (Griffin and Mac Suibhne 2006, 122). It was commonly situated off the Irish western coast, or "upon the N orth of Ireland" (0-Brazile 1675, Sig A2, 3). It was also mentioned by Irish legend as "Brendan's Island," in reference to the place that the saint visited on his missions.

In the seventeenth century, Brazile had a hold on the imagination of the members of learned circles. Its existence was acknowledged in Robert Hooke's diary, a reputed member of the Royal Society. In spite of this, however, the name "Brazile" has often been related to lying; as Barbara Freitag notes, "its deceptive nature serves to comment on shifty matters-be they in a political, religious, or social contextgenerally through use of sarcasm, ranging from mild mockery to elaborate hoaxes" (2013, 131). Head's versions of the discovery of Brazile fit this interpretation, since he comments on the hypocritical nature of his society (The Floating Island), and experiments with different narrative forms in which the boundaries between credibility and deception are far from clear (The W estern W onder and 0 -Brazile). I contend that the island became for Head a means to re-connect with his I rish origins, at the same time that his choice of genre gave him a chance to approach his object of study from an external and knowledgeable perspective.

The imaginary voyage had its own method of proving its veracity, consisting, for example, in the citation of travel accounts and testimonies deemed to be authentic (Tieje 1913, 218). Head uses this strategy in 0 -Brazile, but particularly in The W estern W onder, where he

O Brazeel is described as a Fool's Paradise (in Freitag 2013, 133). Johnson points out that Hy-Brazil stood for the Garden of Hesperides of classical mythology (1999, 114). 
reinforces the believability of the incredible elements of his story by detaching his work from previous fictions of travel:

New Discoveries of late, areas much admired as Miracles of old, and as difficultly believed, notwithstanding the variety of apparent proofs which demonstrate their undoubted Verity; and without question this Incredulity proceeds from no other cause, than the abuse of Belief, occasioned by such monstrous Fictions as the Isle of Pines, A N ew W orld in the M oon, with the like Lunatick Stories, by which the credulous World hath been misguided into a Faith wholly preposterously erroneous and ridiculous. (1674, Sig A2)

Exemplars of imaginary travel narratives like the ones mentioned above are described by Head as pure pieces of fiction that cannot be taken seriously, despite the fact that he imitates very closely Neville's The Isle of Pines (Freitag 2013, 139-40). Yet, at the same time, by invoking Neville's work and referring subliminally to the stories about voyages to the moon, he inserted his text within the tradition that he claimed to reject. Though apparently dismissing narratives of voyage and discovery for being products of the imagination, his own stories alternate between rational evidence and fanciful exercise.

In the Epistle to the Reader and through the literary persona of Robert Owe-Much, in The Floating Island Head confesses that this narration is his own corrective response to "errours and fopperies" and in particular to "the debauchery of a Fop-Jaunty Suburbian." In his view, the country in general, and the city of London in particular, are subjected to "insufferable abuses" (1673, Sig A2). Owe-much refers to the creation of this allegorical and satirical piece as a means of escape at a time when he was hiding from his creditors. His text is, therefore, a peculiar imaginary journey "from Lambeth to the Bridge on one side, and back again the other, recounting all remarkables between the two Shores" (1673, Sig A2), narrated by James Standish, stationer, at a special meeting of the Society of Owe-much, and for the benefit of its associates, whose names al so have a clear allegorical meaning. ${ }^{10}$ The expedition sets out with the purpose of avoiding inhospitable places and of founding their own colonies where they could disperse without risking their freedom (1673, Sig B2). It culminates in a mordant critique of London manners. In the course of their voyage, they discover a continent, Terra del Templo-the Temple-and find

${ }^{10}$ To give a few examples, Giles Sweeting is a confectioner, William Whiting the colorman, and Humphry Holland, the linen-draper (1673, Sig B). 
places like the Savoy, part of the Liberty of the Duchy of Lancaster, or Fulwoods Rents in High Holborn, other sanctuaries for those in debt, meticulously described by Standish. Soon, thefloating island is within sight, and the narrator provides its spatial coordinates with a great deal of precision: "The Christian-shore [lies] to the N orward, and the Turkish-shore to the Southward, bounded to the Eastward with PontTroynovant, but to the Westward thereof, you may sail up the Streights till you go as far as $\mathrm{M}$ aiden-head, and farther, crossing the Equinoctialline" (1673, Sig C2, 13).

As the mythical Brazile, this newly-discovered land is inhabited by colossal and fabulous creatures, whose function is to extend the knowledge about this exotic place as much as to entertain readers, at the same time that their very existence creates wonder and suspicion about their credibility. In line with Judy Hayden's claim about the contribution of seventeenth-century travel narratives to the dissemination of knowledgeand the establishment of fact, I argue that Head perfects a method of chorographical analysis in The Floating Island, by providing a detailed account of people, fauna, flora and manners in an allegorical fashion, in thelight of the instructions given to travelers and mariners by members of the Royal Society, who sent them inquiries to improve their methods of observation of foreign lands (Hayden 2012, 8, 10). ${ }^{11}$ In his own words, he recounts "the Character of the Inhabitants" as well as "their Humours, N atures, and Dispositions" (1673, Sig C). Though not a conventional travel narrative, The Floating Island uses the motif of the journey, and above all, the customary descriptions found in travel writing, as an excuse to draw a satirical map of different areas and emblematic London sights. In this way, the allegorical reference to a number of real locations compensates for the unreliability of Standish's narration. In relation to these marvelous travel accounts, Daniel Carey affirms that the acceptance of the wonderful and the monstrous promoted a "fluid exchange between travel, narrative, and natural history" which more often than not "masked rather than exposed problems of belief, testimony, and evidence, perpetuating an economy of error in which knowledge was both advanced and retarded" (1997, 269). In this

${ }^{11}$ In "The House of Experiment in Seventeenth-Century England," Steven Shapin explains how in the seventeenth century literature runs parallel to a systematic experimentation carried out by the natural sciences, and that the convergence of both is what enables the institutionalization of empirical knowledge. Testimony becomes a crucial element in the acquisition of geographical knowledge $(1988,375)$. 
sense, by imitating the principles of chorography using a purely literary discourse, The Floating Island presents very familiar places and social types in disguise, against which its author directs his mordant critique. Thus, Head's use of the procedures and the methods of geographical observation is not ai med at the expansion of knowledge but at expressing stylistic and literary concerns. In this work, rather than scientific interest, Scoti M oria has a chorographical-cum-literary interest, as it appears as an allegorical sanctuary and a refugefor social outsiders like Head or Owe-much's crew, for that matter. The narrative concludes with a fair account of "the manners and dispositions," the "Religion, Laws, and Customs" of the Ramallians (1673, Sig E2), as well as about the practices of their enemies, the London authorities. Anticipating a sardonic Swiftian style, Head concludes this piece by offering a sarcastic portrait of different contemporary types, as shown by his illustration of a cosmographer: "He that boasts of his Travels, and impudently professeth to have been in places he never saw but in a Map" (1673, Sig E2), in a way privileging testimony and first-hand experience over theoretical knowledge.

It is precisely the importance and the credibility of oral testimony that Head emphasizes in the next two fictions, The W estern W onder and 0 -Brazile. In the former, he presents the Brazeel island as a "New Discovery" which he substantiates by applying the scientific method. He points out its material presence in documents-"your own observations out of Strabo, and other ancient Geographers, in whose Maps you may find the Island, its name, and situation" (1674, Sig A2, 2)-, while referring to the unreliability of certain written testimonies. Side by side with cartographic references, $\mathrm{Head}$ also relies on oral testimonies and describes the island as "Inchanted." In the end, it is not a question of material evidence but of belief. Fishermen's testimonies, however, are deemed unreliable by Head himself, since he feared 'those Relations will belook' $d$ on as the Chimera's of a junior Q uixot, or foolish Fictions, undeserving the Registry of a serious and judicious memory, sincethey seem to giveT om Coriat the Lye, and run away with the Whetstone from our famous Knightly M andevil" (1674, Sig A2, 2). Therefore, no matter how wonderful first-hand accounts may seem, Head implies that travel writing is equally unreliable and deceptive. The anonymous narrator of The W estern W onder, though perplexed by the incredible accounts of travelers and seamen, relies on their reports because they coincide in the essential description of 
the island and its inhabitants; this, despite the fact they were not initially veritable sources of information and knowledge, since they are seen by the narrator's acquaintances as "a company of ignorant Fellows, who had neither reason, nor sense enough to distinguish a blue Cloud from Land" (1674, Sig A2, 5). Spurred by these mariners' testimony, the narrator is paradoxically finally confirmed of the isle's existence after a dream, as a result of which he takes a ship "on October the $9^{\text {th }}, 1672$ " $(1674$, Sig B, 8) and sails in search of Brazile.

If The Western $W$ onder tries to foster verisimilitude through firsthand testimony and by constant appeals to truth, in 0 -Brazile Head continues dressing up a fictional motif as if it were non-fictional, and thus, true, by choosing the format of the letter, which was written and posted, it is claimed, a few months before the text's publication, and by suggesting the veracity of the story on seemingly incontestable grounds: firstly, the island has been included on ancient and modern maps, and secondly, the addressee's cousin, "a wise M an, and a great Schollar," has even paid a patent on the island (1675, Sig A2, 4). Hamilton also provides the exact measurements of the place, these being "above 60 miles in length, and above 30 in breadth" (Sig A2, 8). At the same time, the narrator detaches his narrative from imaginary accounts of enchanted islands- "I know there are, in the World, many Stories and Romances, concerning Inchanted Islands, Castles and Towers, \&c." (1675, Sig A2, 3) - , and hebrings his story closer to home by referring to an island on the Irish coast. The narrator also stresses the validity of the story providing historical data, like the fact that a Member of Parliament in Dublin informed the House of Commons about O-Brazeel in 1663. Hamilton claims, though, that the time of enchantment was over, since the island's existence had been proven. Furthermore, the testimony of other reliable witnesses, like Captain John $\mathrm{N}$ isbet and his crew, is meant to add to the truth of his account.

In the three texts under inspection, Head employs similar techniques and reproduces analogous descriptions in respect to wonder. In The Floating Island, the crew of debtors describethestrange beings they find upon coming ashore: a mysterious "thing in glorious habit but with a face as black as hell" which they takefor a "She-D evil," wearing a mask, and also mighty harts, "whose horns are of the comliest branch and spreading that can be; whose dimension and extension is unfathomable" (1673, Sig C2, 11, 12). They also see another monstrous being, identified as Giant Colbron: "we were so 
near that we could look into his very entrals [sic], his belly being wide open, and could perceive a very strange motion within, whilst his arms were continually agitated circularly" (1673, Sig C2, 13). This gigantic being reminds the narrator straightforwardly of the quixotic adventure of the giants and the wind-mills: ${ }^{12}$

Fear did so wing our flight, and the wind so largely contributed to its assistance, that in a little time we found our selves not in a condition to be harm'd or prejudiced by that Gigantick Scare-crow: had we had as much valour as there was in D on-Q uixot, one assault would have prov'd him a meer airy flash, and could do nothing but cry, saw, saw. (1673, Sig C2, 13)

In spite of what senses declare, Head's narrator is convinced that this is only a vision, a "meer airy flash," which would vanish at the wink of an eye, adopting in this way a quixotic personality but also Sancho Panza's clear understanding. In their exploration of the floating summer-island, they also encounter other mythical beings, Christian and Barbarian A mazons, living on each shore; and mating with "their Bully-H uffs and H ectors" once a year (1673, Sig C2, 14). ${ }^{13}$ Furthermore, the crew's descent to the bowels of the earth is similar to Aeneas' descent into hell (1673, Sig C2, 14), whereas in their circumnavigation of the island they spot men-mermaids (1673, Sig D2, 20).

The W estern $W$ onder and 0 -B razile coincide in the representation of wonderful elements. The former reproduces the report of several anonymous mariners, one of whom claimed to have watched the mysterious island from his ship and spotted some monstrous men who looked like "walking Oaks," whose hands waving at him were like "Wind-mill Sails," a new reference to Cervantes's text (1674, Sig A, 3). The Tempest also resonates in this work, as Shakespeare's unnamed island and Head's Brazile are both magical and enchanted, difficult to spot and only discovered after a shipwreck. In The W estern W onder, we are given the testimony of another sailor who claimed to

\footnotetext{
12 Head's travelers refer to the quixotic elements in this adventure, looking at giants who move their arms as if they were windmills. Don Quixote confounded the windmills with the arms of the giant Briareo (D on Q uixote 1998, I, viii, 88), while in The Floating Island, Head situates his mythology closer to home in choosing Colbron, a legendary giant defeated by Guy of Warwick.

${ }^{13}$ Especially in The Floating Island, Head introduces some of the terms and characters he mentions in The Canting A cademy, or, the D evils cabinet opened, like the Bull-H uffs and Hectors (1673).
} 
have seen the place, and who is compared to "the Usurper Trinkelo," in his wish to be appointed Viceroy of Brazile. A thick mist, nonetheless, conveniently blocks their view and they lose sight of the isle. Head's narrator refers to scientific debate, though, in particular to the veracity of the theory about the multiplicity or plurality of worlds, in order to justify the existence of wonderful beings. In his above-mentioned dream, a gigantic eagle transports him to an island, where he was met by "millions of Devils, and horrid Spectrums [...] and other very strange apparitions" (1674, Sig B, 6). He was brought later to a land of milk and honey, and met people who went about stark naked and worshipped the Devil, the Prince of the Air (1674, Sig $B, 7)$. On waking up, he was convinced that he was going to be the discoverer of O Brazeel, the point at which the account of the voyage begins. Stormy weather and a shipwreck prevented him from discovering the desired place and from there on the narration focuses on the particulars of visiting Montecapernia, which has been connected with Irish social types and manners (Freitag 2013, 140). ${ }^{14}$

A similar wonderful event is narrated in 0 -Brazile, or the Inchanted Island. After reaching land, Captain Nisbet and his crew saw a very ancient man who, accompanied by someten others, and in theScottish tongue, invited them to go ashore. He explained how his ancestors had been living under the influence of a Necromancer, who ruled tyrannically and kept the island invisible, as under a spell. Thenatives had been inadvertently rescued by $\mathrm{Nisbet}$ and his mariners upon them kindling a fire on the island. With due regard to their help, they were given immense amounts of gold and silver of an ancient stamp, which they could show on their return as material proof of their miraculous adventure.

\footnotetext{
${ }^{14}$ The language spoken, similar to Gaelic, the staple food of the natives- "a thin Oatcake [... ], a little Sheeps-milk Cheese, or Goats-milk, boyl'd Leeks, and some Roots" (1674, Sig E, 31)-, their inclination for music, and their Christian-most probably Catholic-religion (1674, Sig E2, 35), makethecomparison with I reland feasible. Head's view of Ireland is of a mythical land, a natural place, now in decadence, governed by monstrous rulers, whose influence is lasting on the natives but, at the same time, easily dissipated by virtue of the innocuous actions of strangers. A colonial interpretation of their expedition is also called to mind when considering not only the civilizing and restorative impact of the adventurers-or discoverers-, but also the willing submission and utter generosity of the islanders. They are well-meaning, though vicious and primitive, as backward-Head seems to imply—as their faith.
} 


\section{Conclusion}

In his geographical narratives, Head uses wonder to explore the limits of his readers' credulity, by asking them to believe at the start, only to make them read it as a fiction. Like other writers before him, most notably Cavendish in The Blazing World, Head situates elements of wonder almost on the same level as elements of verisimilitude, and in so doing he relies on a credible context in which some fantastical elements are interspersed. Works like The W estern Wonder and 0 B razeel dwell in the slippery terrain between history and romance, as, to a certain extent, does the allegorical text The Floating Island. This combination of truth and wonder also helps the author to plead for the endless possibilities of fiction-making, since within its "safe" boundaries, even improbable events are possible. Head's purpose, however, is not to deceive but to instruct his readers and to celebrate the all-inclusive nature of fiction. However, he seems to suggest that the existence of Scoti M oria or Brazile island is either as "improvable" or as believable as the wonderful events narrated in ancient and contemporary travel accounts and, by extension, as the marvelous occurrences his narrators and characters reproduce.

Loveman has described two of Richard Head's travel fictions, The Western Wonder and, above all, 0 -Brazile, as shams, a form that imitates truth, a "fraud that takes between genres," to use Carey's words (in Loveman, 2008, 78). At a time when truth was gradually being appropriated by the institutions of knowledge, and was in the hands of a social and intellectual elite, Head invites a skeptical reading of these texts which rival true travel accounts, and privileges individual testimony, regardless of social extraction. His geographical fictions escape clear-cut categorizations and prove that representations of truth in travel narratives can be easily manipulated. More than accessories to knowledge, as members of academic and scientific circles prescribed, fictions of travel becomein Head'sliterary universe vehicles of social critique and entertainment.

\section{References}

Adams, Percy G. 1983. Travel Literature and the Evolution of the Novel. Lexington, Kentucky: The University Press of Kentucky.

Bayer, Gerd. 2016. N ovel H orizons: The Genre M aking of Restoration Fiction. Manchester: Manchester University Press. 
Behn, Aphra. 1994. Oroonoko and O ther Writings. Edited by Paul Salzman. Oxford: Oxford University Press.

Blum, Elizabeth, and Paul Richard Blum. 2011. "Wonder and Wondering in the Renaissance." In Philosophy Begins in Wonder: An Introduction to Early $M$ odern Philosophy, Theology and Science, edited by Michael Funk Deckard and Péter Losonczi, 1-42. Cambridge: James Clarke \& Co.

Carey, Daniel. 1997. “Compiling Nature's History: Travellers and Travel Narratives in the Early Royal Society." A nnals of Science 54: 269-92.

Carey, Daniel. 2012. "Inquiries, Heads, and Directions: Orienting Early Modern Travel." In Travel Narratives, the New Science, and Literary Discourse, 1569-1750, edited by Judy A. Hayden, 25-51. Aldershot: Ashgate.

Casaubon, Meric. 1668. Of Credulity and Incredulity in things $\mathrm{N}$ atural, Civil, and D ivine. London: Printed by T.N. for Samuel Lownds.

Cavendish, Margaret. 1992. TheBlazing W orld \& O ther W ritings. Edited by Kate Lilley. London: Penguin.

Cervantes, Miguel de. (1605) 1998. D on Q uijote dela M ancha. Edited by Alberto Blecua. Madrid: Espasa.

Congreve, William. 1692. Incognita: or, Love and Duty Reconcil'd. A Novel. London: Printed for Peter Buck.

Cormack, Lesley B. 1991. “'Good Fences Make Good Neighbors': Geography as Self-Definition in Early Modern England." ISIS 82: 639-61.

Cressy, David. 2006. "Early Modern Space Travel and the English Man in the Moon." A merican H istorical Review 111 (4): 961-82.

Das, Nandini. 2016. "Romance and the Reinvention of Wonder in the Early Seventeenth Century." In Seventeenth-Century Fiction: Text \& Transmission, edited by Jacqueline Glomski and Isabelle M oreau, 19-33. Oxford: Oxford University Press.

Davis, Lennard J. 1983. Factual Fictions: The O rigins of the English N ovel. New York: Columbia University Press.

Dunton, John. 1683. The Informer's D oom: Or, an A mazing and Seasonable Letter from $U$ toia, Directed to the $M$ an in the $M$ oon. London: Printed for John Dunton.

Freitag, Barbara. 2013. Hy Brasil: The Metamorphosis of an Island. From Cartographic Error to Celtic Elysium. Amsterdam: Rodopi.

Fuson, Robert Henderson. 1995. Legendary I slands of the O cean Sea. Florida: Pineapple Press.

Glomski, Jacqueline, and Isabelle Moreau, eds. 2016. Seventeenth-Century Fiction: Text \& Transmission. Oxford: Oxford University Press. 
Griffin, Michael, and Breandán Mac Suibhne. 2006. “Da's Boat; or, Can the Submarine Speak? A V oyage to O -Brazeel (1752) and Other Glimpses of the Irish Atlantis." Field D ay Review 2: 111-28.

Hayden, Judy A. 2012. "Intersections and Cross-Fertilization." In Travel $\mathrm{N}$ arratives, the $\mathrm{N}$ ew Science, and Literary Discourse, 1569-1750, edited by Judy A. Hayden, 1-21. Aldershot: Ashgate.

Head, Richard. 1663. Hic \& U bique, or the Humours of Dublin. A Comedy. London: Printed by R.D. for the author.

Head, Richard. 1665. The English Rogue. London: Printed for Henry Marsh.

Head, Richard. 1666. The Red-Sea: Or the D escription of a most H orrid, Bloody and never yet paralel'd Sea-Fight between the English and the Dutch. London: Printed by Peter Lillicrap.

Head, Richard. 1667. The Life and D eath of M other Shipton. London: Printed for B. Harris.

Head, Richard. 1673. The Canting A cademy, or, the D evils cabinet open ed, wherein is shown the mysterious and villainous practices of that wicked crew, commonly known by the names of hectors, trapanners, gilts, $\&$ c. London: Printed by $F$. Leach for Matt Drew.

Head, Richard. 1673. [Franck Careless] TheFloating I sland: or, A N ew D iscovery, Relating The Strange Adventure on a late V oyage, form Lambethana to V illa Franca, alias Ramallia, To the Eastward of Terra del Templo. London: s.n.

Head, Richard. 1674. The W estern Wonder: or, O Brazeel, and Inchanted Island discovered; with a Relation of Two Ship-wrecks in a dreadful Sea-storm in that discovery. London: Printed for N.C.

Head, Richard. 1675. 0-Brazile or the Inchanted Island, being a perfect R elation of the late D iscovery, and wonderful D is-Inchantment of an Island on the $\mathrm{N}$ orth of Ireland: With an Account of the Riches and Commodities thereof. Edinburgh: Printed for William Crook.

Johnson, Donald S. 1999. Phantom I slands of the Atlantic: The Legends of Seven Lands that N ever W ere. London: Souvenir Press Limited.

Katanka, Margaret Claire. 1975. Richard Head (1637?-1686?): A Critical Study. Ph.D. diss. University of Birmingham.

Loveman, Kate. 2008. Reading Fictions, 1660-1740: D eception in English Literary and Political Culture. Aldershot: Ashgate.

Manley, Delarivier. 1705. The Secret History of Q ueen Zarah and the Zarazians; Being a Looking-Glass for ------- in the Kingdom of Albigion. Albigion.

Matytsin, Anton. 2013. "Scepticism and Certainty in Seventeenth- and Eighteenth-Century Speculations about the Plurality of Worlds." Science et Esprit 65 (3): 359-72. 
McKeon, Michael. 1987. The O rigins of the English N ovel, 1600-1740. Baltimore: The Johns Hopkins University Press.

Moreau, Isabelle. 2016. "Seventeenth-Century Fiction in the Making." In Seventeenth-Century Fiction: Text \& Transmission, edited by Jacqueline Glomski and Isabelle Moreau, 1-16. Oxford: Oxford University Press.

Salzman, Paul. 1985. English Prose Fiction, 1558-1700: A Critical History. Oxford: Clarendon.

Salzman, Paul. 1999. “Theories of Prose Fiction in England: 1558-1700." In The Cambridge History of Literary Criticism. Vol. III. The Renaissance, edited by Glyn P. Norton, 295-304. Cambridge: Cambridge University Press.

Sell, Jonathan P. 2006. R hetoric and W onder in English T ravel W riting, 1560-1613. Aldershot: Ashgate.

Shapin, Steven. 1988. "The House of Experiment in Seventeenth-Century England." Isis 79(3): 373-404.

Shapin, Steven. 1994. A Social History of Truth: Civility and Science in Seventeenth-Century England. Chicago: University of Chicago Press.

Tieje, Arthur Jerrold. 1913. "A Peculiar Phase of the Theory of Realism in PreRichardsonian Fiction." PM LA 28 (2): 213-52.

\footnotetext{
How to cite this article:

Villegas López, Sonia. “Truth and Wonder in Richard Head's Geographical Fictions." SEDERI 30 (2020): 117-37.

https:/ / doi.org/ 10.34136/ sederi.2020.6

A uthor's contact: villegas@dfing.uhu.es

Postal address: Departamento deFilología Inglesa - Universidad deHuelva - Avda. Tres de Marzo s/ n - 21071, Huelva - Spain 



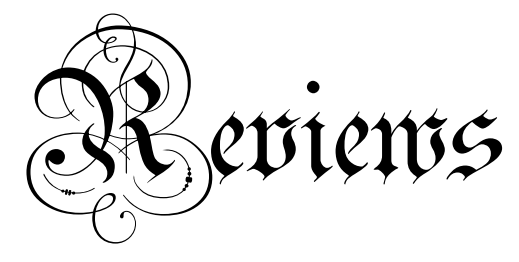





\title{
M agdalena Cieślak, 2019. Screening Gender in Shakespeare's Comedies: Film and Television Adaptations in Shakespeare's Comedies. New York/London: Lexington Books
}

\author{
Coen Heijes \\ U niversity of Groningen, The N etherlands
}

Thefield of academic research on Shakespeare and screen adaptations has been rapidly expanding over the past decades, and Cieślak's interdisciplinary study provides a welcome critical addition. The author has chosen a focused approach, limiting her attention to twenty-first century film and television adaptations of Shakespeare's comedies which she analyses through the lens of gender politics. Rather than choosing a wide angle, she has decided to zoom in on seven productions: four cinematic productions and three television adaptations from the BBC series ShakespeaReT old. In a highly topical book, also considering the ongoing \# explores the tensions and negotiations between early modern attitudes towards gender and the way twenty-first century adaptations relate to those issues in terms of current gender politics. In this process, the study discusses the interpretative strategies that productions employ in accommodating the early modern constructs, how they disregard, apologize for rationalize or even drastically rewrite these constructs, and how that relates to present-day concerns with gender issues.

In the introduction, Cieślak broadly sketches the background of her study and, relying strongly on Phyllis Rackin, she argues how the extent of patriarchal oppression in earlier centuries is often "overdone to highlight the democratic achievements of the present" (11). While acknowledging the disadvantageous position of women in early modern England, she discusses how, in some respects, their society may have been even more liberal than today's. In the remainder of the introduction, she places her research within the field of adaptation studies and feminist and gender studies, mainly as they relate to Shakespeare's comedies. This provides a useful general introduction to the topic, although, in attempting to discuss such a wide range of perspectives in some twenty pages, it is almost inevitable that the introduction tends more towards an overview than towards a critical 
positioning in the field. The author herself also acknowledges this, but argues, perhaps slightly gratuitously, that the very plurality in the field and the many unresolved debates only serveas a propelling force for the dialogue between past and present.

The first section of the study is titled "Doing It 'Straight'" and contains four chapters, each of which discuss a cinematic production: Michael Redford's The M erchant of V enice (2004), Kenneth Branagh's As Y ou Like It (2006), Julie Taymor's The Tempest (2010) and Joss Whedon's M uch A do A bout N othing (2012), respectively. Thetitle of the section refers to the fact that these straight adaptations directly rely on the source in that they use the language of Shakespeare's plays; through the pun on "straight," the author already indicates the problematic nature of the interaction between the gender and fidelity discourse of the films. In these four chapters, the author moves continually between the early modern context of the plays, current readings from a femi nist and gender perspectiveand an interpretation of the films in relation to this context and perspective. In sketching the early modern context and current readings, Cieślak leans heavily on other authors and may be said to be more of a thread that weaves together the many voices that form the tapestry and the discourse behind the four movies. While useful, the real value of the book lies in the parts where Cieślak's own voice is heard more prominently: in the, at times, detailed analysis of the four films and also in her conclusions as to how they accommodate the narrative of the plays in light of today's concerns.

Cieślak's eyefor detail finds for example expression in her analysis of minor characters, such as Caliban, but also in the way she analyzes the silent mini-narratives, such as the end of Radford's M erchant of $V$ enice or the opening of Whedon's M uch A do A bout N othing, and the impact these have on the emotional and political reading of the movies. While there is enough differentiation between the four movies, Cieślak is critical of the quartet, with Branagh's moviebearing the brunt of the criticism, as a simplified, feel-good romantic comedy, ignoring any ambivalence and "not a way to sell Shakespeare anymore" (96). Although she is slightly more sympathetic to the other three movies, sheargues how Radford, whilesympathetic to women's plight, still depoliticizes their subordination. The gender change in Taymor's movie (from Prospero to Prospera) is shown to soften the protagonist's relation with Miranda, Ariel and Caliban, but also turns 
her into a formidable and strong woman, who only manages to survive by adopting the very terms of patriarchal society, thereby foregoing the chance to redefine these power relations. Whedon's movie is today perhaps even more relevant than ever, originating from and set against the background of "leisurely Southern California, [...] buzzing with eroticism and desire" (138). Following one disclosure after another in Hollywood, it is ironic and troubling that this version of $\mathrm{M}$ uch $\mathrm{A}$ do about $\mathrm{N}$ othing almost seems to mirror the context that gave rise to these events. Although never referring directly to this, Cieślak argues how the movie, while sympathizing with the wrong done to women, can do no better than absolve men and praise women for their ability to endure in silence.

The second section contains three chapters, which discuss three 2015 television adaptations in the BBC Shakespea ReTold series: M uch A do about $N$ othing (dir. Brian Percival), The Taming of the Shrew (dir. David Richards) and A M idsummer N ight's D ream (dir. Ed Fraiman), respectively. Rewritten in contemporary language and set in presentday contexts, the series aimed at modernizing the plays and adapting them to suit politically "correct" tastes and concerns, particularly regarding gender politics. Where Whedon's M uch A do A bout $\mathrm{N}$ othing, for example, sympathizes with Beatrice on account of her bad treatment, the BBC version presents a far more self-confident and intelligent woman and paints Benedick as a "[... a loser. Unable to commit, cowardly, and narcissist" (162). It is a pattern that we see recurring in all of the three adaptations, where the female characters are presented as far more mature than their male counterparts (so much so, that one may wonder why on earth someone would ever fall in love with them). In The Taming of the Shrew, by many considered to be the best of the series, Cieślak argues how on the one hand the same, almost apologetic correctness on gender politics seeps through the movie, while on the other hand the heteronormative traditions keep informing this production, as in the ending where a marriage based on love and a happy family life are presented as ultimate ideals. Interestingly, in A M idsummer N ight's $D$ ream, the attention is focused more on the maturer marriages, between Oberon and Titania and Theo (a blend of Theseus and Egeus) and Polly (Hippolyta) rather than on the young lovers. While the film demonstrates that marriage requires wisdom, compromise and respect and shows the gradual change of the obnoxious Oberon and Theo into more caring men, the real issue is their obliviousness to their behavior, and it is here that 
Cieślak rightly draws a parallel with a standard \# \# eToo defense: I never realized my "behavior was abusive or problematic" (218).

In her book, Cieślak analyses many of the problems that cinematic and television productions encounter when adapting Shakespeare's comedies for a present-day audience. While the BBC series is more explicitly and politically "correct" when dealing with gender politics, the author shows how these series also adopt a generally onedimensional vision of relationships and adhere to many of the norms of the romantic comedy. Cieślak rightly challenges the screen adaptations and shows how they fail to explore the variety and extremity in ongoing marital abuse, how they simplify both the problems and the solutions, stereotype women and men, ignore class and ethnicity, and generally recycle heteronormative standards and traditional values. A potential drawback of the book might be the limited choice of these specific seven productions. Cieślak herself is aware of this, and readily points out that her exclusive focus on English language productions is troubling, precisely because they tend to adopt a universalizing tone, projecting a vision and standards that are assumed to be global. Which, of course, they are not. More detailed research into other language screen adaptations of Shakespeare's comedies might offer a fruitful area of further research and possibly unveil more challenging or radical approaches to the plays' gender ideologies than these specific adaptations. With all the insightful analysis in her timely book, Cieślak has hopefully also provided an impetus for further research in this highly topical field.

H ow to cite this review:

Heijes, Coen. Review of Magdalena Cieślak, Screening Gender in Shakespeare's

Comedies: Film and Television Adaptations in Shakespeare's Comedies (New York/

London: Lexington Books, 2019). SED ERI 30 (2020): 141-44.

Author's contact: c.p.a.heijes@rug.nl

Postal address: Faculty of Economics and Business - University of Groningen Nettel bosje 2 - 9747 AE Groningen - The Netherlands 


\title{
N eil Corcoran. 2018. Reading Shakespeare's Soliloquies: Text, Theatre, Film. Bloomsbury A rden Shakespeare. London: Bloomsbury Publishing \\ Efertpi M itsi, ed. 2019. Troilus and Cressida. A Critical Reader. The A rden Shakespeare. London: Bloomsbury Publishing
}

\author{
Jonathan P. A. Sell \\ U niversidad de A Icalá de $H$ enares, Spain
}

TheArden production linecontinues to roll unabated. Neil Corcoran's Reading Shakespeare's Soliloquies: Text, Theatre, Film is a useful guide to what for many are the very essence of Shakespeare's dramatic achievement, the heart of the mystery and, in consequence, Shakespeare being Shakespeare, the holiest of Western literary holies. As Corcoran leads us to the inner sanctum, his hand remains commendably steady, his head admirably lucid and our path uncluttered by thronging theorists (except for the occasional Freudian visitation). Corcoran's book is a minor monument of common-sense with a methodology no more sophisticated than an objective marshalling of the facts coupled with sensitive close-reading and the absence of any axe to grind. For that reason, it has a slightly outmoded feel to it, unless, of course, down-to-earth practical criticism is coming back into fashion. Even the title has a reactionary ring in its initial, Charles Lamb-like prioritizing of reading over performing or viewing in performance; the subtitle, "Text, Theatre, Film" is tagged on rather awkwardly, although Corcoran's book is generous-and perhaps most rewarding - in its attention to theatreand film. It is, then, a study which, unfazed by the cultural magnitude of its subject, eschews the ecstatic and, unimpressed by the -isms of academe, shuns the "theoric." As such, it is ideal for its intended audience of general readers and university and drama-school students.

Part I, "Soliloquies in Practice," is divided into two chapters. The first gives us a feel for what a Shakespearean soliloquy is by walking us through Macbeth's "Is this a dagger?" speech. Although Corcoran doesn't make the point explicitly, his implication is that the trick of the soliloquies lies in their language and in our sympathy with their 
speakers, in connection with which he quotes Thomas de Quincey's famous distinction between "a sympathy of comprehension" (which we feel) and "a sympathy of pity or approbation" (which we do not). Corcoran's take, stretching back via eighteenth-century British ethics and the crucial, psychological-moral systems of Edmund Burke and David Hume, to Philip Sidney and Sebastian Minturno, and, ultimately, to the mutual speaker-audience psychopathologies stimulated by affective rhetoric, is time-honored and traditional. The second chapter emulates Henry Reed's war-time poem, "Naming of parts," in attempting to identify the different attributes of a Shakespearean soliloquy. This anatomical exercise is the least satisfying section of the book: a Shakespearean soliloquy is not an Enfield rifle and some of Corcoran's attributes fail to convince, few are actually common to all the soliloquies, while many are not intrinsic attributes but contingent accidents ("Some soliloquies [...] are exceptionally well-known [... which] makes them particularly difficult for actors to perform" [48] or "Sometimes we may value a particular soliloquy [...] because it contains an intensely memorable line or two" [(51]).

Part II, "Soliloquies in Theory," is more satisfactory. The first of its six (brief) chapters explores the critical (Restoration, Romantic, Victorian) and literary (from Jane Austen's "free indirect speech" to Krapp's Last Tape) reception of the Shakespearean soliloquy. The second sketches the origins of the Shakespearean soliloquy in classical, medieval and Renaissance drama, with particular emphasis on Marlowe (predictably) and Montaigne (less so), who earns a place on the strength of his notion of "the fluctuating self." How early modern authors and audience conceived of the self is treated very summarily in Chapter 3, as well as how Shakespeare's representations of the self have been understood humanistically (Harold Bloom), politically (Stephen Greenblatt, Raymond Williams, Catherine Belsey) and religiously (Brian Cummings). Chapter 4 provides a useful account of how soliloquies have been staged over the centuries. Chapter 5 illustrates threekinds of soliloquy, "choral," "political" and those to do with matters of sexuality or gender: the conceptual problems involved in categorizing according to different criteria (form, interpretations and contents) are overridden by persuasive readings and compelling references to theatrical and cinematic performances. Chapter 6 draws on Erving Goffman-although Thomas Hobbes and others beat him to it by three hundred years-to 
reflect cursorily on the performative nature of identity as it transpires through Shakespeare's characters and their soliloquies.

Corcoran's book is al ways more gripping when it gives theory and history a breather and takes off for the theatre or cinema. Not surprisingly, therefore, Part III, "Soliloquies in Performance," is the most satisfying, consisting as it does of edited interviews with eight contemporary Shakespearean actors. Here we sense the passion, the excitement, the thrill of the soliloquies which Corcoran's measured criticism tends to mute or silence. These are the pages that will have the more bookish academics (like this reviewer) shamefacedly acknowledging with Diderot that we'd be pretty dull and inept creatures indeed if we only knew what we had read. Corcoran's interviewees have been on the rack with Shakespeare's characters, have bared themselves to their audiences with only Shakespeare's words to protect them: they know, they have experienced, the soliloquies like nobody else. What emerges most strikingly is the paradoxically communal nature of soliloquy: Mariah Gale explains how when the actor is most alone, she/ he most needs other people; Pippa Nixon highlights the actor-audience togetherness achieved and required by soliloquy; Jonjo O'N eill, Jonathan Slinger and Alex Waldmann are fascinating on using the audience as a soundingboard, on interacting with it, or on "dip[ping] in and out of your awareness of the audience" (153). Part III alone makes Corcoran's book worth reading.

Part IV, "Soliloquies in Play," offers interpretations of soliloquies as they "work in concert" ([169]) within four plays: Richard III and 3 Henry VI, Romeo and Juliet, and Othello. Corcoran's analyses are thorough and sound, work into the discussion theatrical and film versions, and refer back illuminatingly to some of his actors' comments from Part III. Given the book's compartmentalized organization and disparate material, a conclusion which reinforced main ideas and offered a final synthesis would have been helpful. Overall, Corcoran's Reading Shakespeare's Soliloquies will, one would like to think, be of great value to its intended audience in its demonstration of what can be done with all those speeches-how they can be read or performed. It is just the kind of work this reviewer would have welcomed in his undergraduate days, although that might be uncertain praise as those were the days before social media, Internet and mobile phones, days when British summers were 
occasionally warm, winters al ways cold and snowy, the welfare state was still (just) something to be proud of and thetrade unions still (just) had some muscle. Only time will tell whether Corcoran's book is in tune with the current zeitgeist-one hopes it is, fears it may not be.

A recent addition to the A rden Early M odern Drama Guides series, Efterpi Mitsi's edited collection of essays, Troilus and Cressida: A Critical Reader, is assuredly a child of its times. Its contributors-from Hungary, Wales, Scotland, Greece (four) and Portugal-attest to the geographical decentering of English Studies and are all earnestly professional. But there is no passion, no fire, nothing that might incite new readers to take on a notoriously intractable, inhospitable and difficult work. Troilus and C ressida is a great play, but no one's favorite: like an Almerian desert-scape or a Bruckner symphony, it is very impressive but no place for a picnic, no soundtrack for loving memories-or at least, it would take a very great critic to have readers unpacking their sandwiches or reaching for Spotify. Unfortunately, readers of this volume will carry on their journeys el sewhere, listen to the same music as al ways.

To be fair, the first ten pages of Mitsi's introduction are an exemplary synthesis of some of the play's main themes, its performance and reception history, and its place in the Elizabethan appropriation of the Trojan matter. To be fair, too, Chapter's 1-3 fulfil their respective briefs competently and exhaustively, providing the sort of material to which the Arden editions of the plays have long accustomed us. Kinga Földváry traces in great detail "The Critical Backstory" of the play from John Dryden's 1679 adaptation, through its eighteenth-century editors and nineteenth-century moralizers and psychologizers, to the war-torn twentieth-century's inevitable engagements. Francesca Rayner offers a comprehensive survey of this self-consciously theatrical play's performance history, its threecentury-long absence (1609-1912) from the stage permitting in-depth accounts of most major modern and contemporary performances: not surprisingly, productions tend to highlight issues of sexuality, gender and war. Johann Gregory sketches the interpretative "state of the art" in a series of cameos of current critical perspectives on the play: historical, linguistic and metatheatrical, psychological, feminist and gender criticism, presentism and ecocriticism.

Chapters 4-7, "New Directions," comprise what the series editors, Andrew Hiscock and Lisa Hopkins, describe in their general 
introduction as "cutting-edge scholarly debate." In the context of the deeply equivocal Elizabethan reception of the Trojan matter, Rob Maslen reads the play as a critique of the exemplarity on which humanist conceptions of literary art depended-predictably enough in a play which rips up all notion of value. Miklós Petí's piece on the play's interrogation of Greekness adds little to Spencer (1962) and Nuttall (2004), both cited here, and is sometimes contradictory: "there is [...] no cosmic background [...] the characters' insistence on the divine motivation [...] exposes the large scheme in which these actions receive their significance" (139). Vassiliki Markidou explores how the play uses the topic of relics to "critique early modern configurations of gender, religion and nation" ([147]): Cressida is figured as a relic, Thersites as an anti-relic protestant, and Troy prefigures morally ruinous London. Noticeably absent, especially given the chapter devoted to him elsewhere by this volume's editor (Mitsi 2017, 119-50), is Thomas Coryat's lament for Troy from amidst what he mistakenly took to be its rubble and his prayer that the new Troy of London, "as much polluted and contaminated with extravagant lusts" (1776:3.277), might avoid a similarly tragic end. Absent, too, is Walter Benjamin, whose ruminations on ruins are highly pertinent to Markidou's discussion and to Maslen's, which contemplates Shelley's Ozymandias in its final paragraph. Paschalis Nikolau's analysis of Greek translations and performances of the play will be of limited interest to most readers; what is missing is any sustained exploration, on the one hand, of the particular challenges posed by Shakespeare's language and, on the other, of the constraints imposed on the translators by the target culture, whether in the form of expectations, conceptual frames or ideologies. In Chapter 8, Richard Stacey suggests ways of teaching the play to undergraduates, chiefly through close textual/ lexicographical analysis or through comparison of different performance choices. He appends a list of "Theatre Resources."

The overall quality of the essays is disappointing; none is startling in its newness. Several are vitiated by poor editing: there are a number of prepositional errors, occasional problems with word choice, and even "A chilleus" and "Aias" $(130,139)$ step out of the margins. There is a very heavy Greek slant-off-stage, the Turks might be muttering, "What about us?" 


\section{References}

Coryat, Thomas. 1776. Coryat's Crudities; Reprinted from the Edition of 1611. To which are now added his letters from India, \&c [...] 3 vols. Vol. 3. London: W. Cater.

Mitsi, Efterpi. 2017. Greece in Early English Travel Writing, 1592-1682. Cham: Palgrave Macmillan.

Nuttall, A. D. 2004. "Action at a Distance. Shakespeare and the Greeks." In Shakespeare and the Classics, edited by Charles Martindale and A.B. Taylor, 209-24. Cambridge: Cambridge University Press.

Spencer, T.J.B. 1962. “'Greeks' and 'Merrygreeks': A Background to Timon of A thens and Troilus and Cressida." In Essays on Shakespeare and Elizabethan Drama in $\mathrm{Honor}$ of $\mathrm{H}$ ardin Craig, edited by Richard Hosley, 223-33. Columbia, MI: University of Missouri Press.

How to cite this review:

Sell, Jonathan P. A. Review of Neil Corcoran, Reading Shakespeare's Soliloquies: Text, Theatre, Film (London: Bloomsbury Publishing, 2018); and Efertpi Mitsi, ed., T roilus and Cressida. A Critical Reader (London: Bloomsbury Publishing, 2019). SEDERI 30 (2020): 145-50.

A uthor's contact: jonathan.sell@uah.es

Postal address: Facultad de Educación, $4^{a}$ planta, 24 - Universidad de Alcalá - Calle Madrid 1-19001 Guadalajara, Spain 


\title{
M ark H utchings, ed. 2019. The Changeling. A Critical Reader. The Arden Shakespeare. London: Bloomsbury
}

\author{
Cinta Zunino-Garrido \\ U niversity of Jaén, Spain
}

The Changeling. A Critical Reader, edited by Mark Hutchings, is a remarkable collection of essays aimed at confirming that Thomas Middleton's and William Rowley's The Changeling is still one of the most compelling tragedies in the history of English drama. This guide, which addresses key textual, critical, and staging features of the Jacobean masterpiece, intensifies the debate on the play by putting forward to modern readers interrogations which, as Hutchings suggests, are worth dwelling on. The contributors to this volume engage in these interrogations, from different yet certainly complementary perspectives, thus creating a series of palpable synergies that indubitably contribute to present the book as an effective multifocal and far-reaching continuum, instead of as a mere assembling of unconnected essays.

Since the mid-twentieth century, and especially after its 1961 professional revival at the Royal Court in London, The Changeling has progressively drawn the attention of scholars. Still, it has been during the last two decades that the play and Middleton's playwriting skills have been praised to the level of Shakespeare's, with more focus on Middleton than on Rowley, about whom scholars still have much to say. Proof of this are the publication of modern critical editions (Thomas M iddleton: The Collected W orks, 2007) and the diverse studies devoted to the ideological and cultural context of Middleton's oeuvre. Among others, seminal studies in this field include journal articles and monographs such as Thomas M iddleton in Context (2011), Thomas $M$ iddleton and Early M odern Textual Culture (2007), The 0 xford $H$ andbook of Thomas Middleton (2012), and Thomas Middleton, Renaissance Dramatist (2009). Although these works offer a comprehensive reading of Middleton and his texts, as well as of his collaboration with other playwrights (see also, for example, M iddleton and Rowley: Forms of Collaboration in the Jacobean Playhouse [2012] and $\mathrm{M}$ iddleton and $\mathrm{H}$ is Collaborators [2008]), a thoughtful and erudite examination of The 
Changeling like the one in this volume brings fresh insight into what is perhaps considered Middleton's and Rowley's best play. In this regard, The Changeling. A Critical Reader constitutes a significant contribution to the study of this seminal play in the vein of other recent analyses such as those of Jay O'Berski (2012) or Michael Neill (2019) in his reissued edition of the play.

The book opens with a very informative introduction in which the editor reviews the most significant aspects of The Changeling, setting the scene for the essays that follow. Focusing on the conditions of the collaboration between the two dramatists, Hutchings explores the peculiarities of the tragedy, its historical and political circumstances, and its textual and dramatic features, to end up suggesting that the text still has much to say to modern scholars, as the ensuing eight chapters seek to prove.

In chapter one, "The critical backstory," Sarah D. Luttfring outlines the different critical perspectives from which scholars have approached The Changeling up to the end of the twentieth century. With a special emphasis on the interpretations of the Beatrice and De Flores story, and the connections between the main plot and the subplot, Luttfring calls attention to the evident convergences and continuities that underlie the manifold critical readings and that contribute to turn the play into a permanent object of critical analysis. Chapter two, "A performance history," complements this overview of the critical narrative of The Changeling, as Jennifer Panek demonstrates here that dramatic performances can indeed raise questions about the interpretation of a text just as academic scholarship does. Panek offers a detailed summary of the staging history of Middleton's and Rowley's masterwork and explains that, although the play remained unstaged until the 1960's, it took less than three decades for it to be recognized as a classic which is now regularly performed-in the traditional or more experimental vein-as part of what is considered the Shakespearean canon. The scope of the latest critical approaches to The Changeling during the last two decades is what Patricia A. Cahill condenses in the following chapter, "State of the art." In her essay Cahill examines the six main areas of research that have determined current scholarship on The Changeling, corroborating, as the previous two chapters equally do, that Middleton's and Rowley's tragedy proves an unremitting source of critical analysis. Thus, even though TheChangeling. A Critical Reader offers a table of contents with no other 
subdivision than that of its eight chapters, the first three, as can be inferred from these succinct notes, perfectly function as a unit that helps readers appreciate the play in its academic and performance history.

The following two chapters, "N ew directions: Embodied theatre in The Changeling" by Peter Womack and "New directions: Doubles and falsehoods: The Changeling's Spanish undertexts" by Berta CanoEchevarría, look beyond this exhaustive account of the critical and performance history of The Changeling in an attempt to enlarge the scholarly responses elicited by the Jacobean tragedy. Without losing sight of The Changeling's performance conditions, Peter Womack explores the offstage and onstage action of the play to argue very convincingly that the effects achieved by the combination of these two theatrical modes somehow appear to encapsulate the intricacies of the unconscious. Womack, however, does not justify this assumption from what would appear an anachronistic twentieth-century perspective; rather, he does so within the context of the seventeenthcentury Protestant practice of self-analysis. Alternatively, Berta CanoEchevarría's inspiring essay delves into the textual sources of The Changeling. She maintains that, even if John Reynolds' The Triumphs of Gods R evenge (1621) is considered the main source for Middleton's and Rowley's story, Gonzalo de Céspedes y Meneses' Gerardo the U nfortunate Spaniard (published in Spanish in 1615 and translated into English in 1622) similarly appears to have influenced the plot of The Changeling. Cano-Echevarría's analysis reveals that not only did the story of Gerardo the U nfortunate Spaniard encourage both dramatists to develop key elements of the play absent in Reynolds's tales, but it also provided the English tragedy with authentic Spanish Golden Age literary material that transcended its mere fictional setting.

The following two chapters again attest that The Changeling, like any other early modern play liable to be revived for twenty-first century audiences, still poses intricate staging questions for modern directors. In "N ew directions: Performing The Changeling: 2006-2015," Sarah Dustagheer focuses on four of the most recent and remarkable productions of Middleton's and Rowley's tragedy in order to explain how the disparities between the conditions of Restoration playhouses and modern-day theatres affect contemporary productions. Especially challenging for modern productions are, as her study shows, the combination of the main plot and the subplot, the 
representation of the physical and psychological enclosure of the characters, and the performance of sex, violence and the quite unfamiliar for present-day audiences-use of asides. A nother kind of performance analysis, more in connection with the screen than with the stage, is what Nathalie Vienne-Guerrin undertakes in chapter seven, "New direction: Loving and loathing: Horror in The Changeling from text to screen." Inasmuch as The Changeling largely hinges upon a clear blend of fascination and repulsion, as illustrated in the prominence given to the body, desire, and abjection, Vienne-Guerrin argues that by no means would modern spectators reject a film adaptation of the play highly influenced by the conventions of the horror genre. Vienne-Guerrin thus addresses the anatomy of horror depicted in The Changeling with the purpose of examining modern film versions (especially Marcus Thompson's M iddleton's Changeling [1998]) and their enactment, against the background of the horror genre, of the play's compelling combination of "loathing and loving."

The book closes with an essay meant to capture the essence of the volume. In this concluding chapter entitled "Resources," Nora J. Williams reviews the manifold readings of The Changeling and proposes a series of resources particularly addressed to teachers-and students-who might consider Middleton's and Rowley's drama an excellent option for classroom study and might therefore take an interest in the critical and performance approaches to the tragedy. However, Williams does not simply outline these debates, she also asks genuinely challenging questions about specific aspects of the play (i.e. human rights issues or the politics of performing disability) that would certainly prove exciting for postmodern reactions to the text. Wisely sealed with a useful list of online resources and an annotated catalogue of modern editions, Williams's essay thus puts an end to this inspiring collection of essays.

To conclude, in The Changeling. A Critical Reader Mark Hutchings is therefore in charge of a series of essays that not only bring together a stimulating guide to the play's critical and stage history, but also provide new work on thought-provoking questions never before discussed. Hutchings's previous research on Middleton, and The Changeling in particular $(2008,2011,2012)$, ensures the rigor and coherence of the volume he edits, which proves a very valuable, practical, and instructive manual for those interested in exploring the 
(c) ederi 30 (2020)

textual and performance complexities of this ground-breaking piece of Jacobean drama.

\section{References}

Gosset, Suzanne. 2011. Thomas M iddleton in Context. Cambridge: Cambridge University Press.

Hutchings, Mark, and A. A. Bromhan. 2008. M iddleton and $\mathrm{H}$ is Collaborators. Plymouth: Northcote House.

Hutchings, Mark. 2011. "De Flores between the Acts." Studies in Theatre and Performance 31 (1): 95-111.

Hutchings, Mark. 2012. "The Changeling at Court." Cahiers Élisabéthains 81: 1524.

Neill, Michael, ed. (2006) 2019. The Changeling. London: Bloomsbury.

Nicol, David. 2012. M iddleton and Rowley: Forms of Collaboration in the Jacobean Playhouse. Toronto: University of Toronto Press.

O'Berski, Jay. 2012. The Changeling. A Guide to the Text and the Play in Performance. Basingstoke: Palgrave Macmillan.

O'Callaghan. 2009. Thomas Middleton, Renaissance Dramatist. Edinburgh: Edinburgh University Press.

Taylor, Gary, and John Lavagnino, gen. eds. 2007. Thomas M iddleton: The Collected W orks. Oxford: Oxford University Press.

Taylor, Gary, and John Lavagnino, gen. eds. 2007. Thomas M iddleton and Early M odern Textual Culture: A Companion to the Collected W orks. Oxford: Oxford University Press.

Taylor, Gary, and Trish Thomas Henley, eds. 2012. The Oxford Handbook of Thomas M iddleton. Oxford: Oxford University Press.

How to cite this review:

Zunino-Garrido, Cinta. Review of Mark Hutchings, ed., The Changeling. A Critical Reader (London: Bloomsbury, 2019). SED ERI 30 (2020): 151-55.

Author's contact: czunino@ujaen.es

Postal address: Dpto. Filología Inglesa - Universidad de Jaén - Campus Las Lagunillas 23071 Jaén - Spain 



\title{
M aría José M ora, ed. 2019. Restoration Comedy, 1671-1682. New York: Teneo Press
}

\author{
Sonia Villegas López \\ U niversidad de H uelva, Spain
}

This is the second volume in a series of four, begun in 2014, which inaugurated Restoration Comedy, 1660-1670, also published by Teneo Press. This consolidated team of researchers from the universities of Seville, Cádiz, Vigo, and Córdoba, are in the middle of a paramount enterprise: the cataloguing of all the extant comedies in the Restoration period. This comprehensive approach allows them, as the Foreword announces, to trace "the development of dramatic models and theatre practice" $(2019,3)$, as well as to provide a thorough description of the texts within the selected range at different levels and an analysis of their most relevant findings. Theirs is a decisive attempt at experimenting with the productive scope of Digital Humanities, as the methods of data collection as well as computation, processing and analysis allow for the combination of qualitative and quantitative approaches, which contribute to innovative and challenging readings of the corpus of Restoration comedies as they had never been studied before. ${ }^{1}$ In this second volume, the contributors have chosen the years 1671-1682, in an effort to include the period of coexistence of the two patent companies, the King's and the Duke's, till their merging into the United Company, and the concurrence of political scandals like the Popish Plot and the Exclusion Crisis.

The volume presents a tripartite structure, comprising a thorough theoretical introduction (pages 4-100), a substantial section including the Comedy Files, with all the plays that integrate the corpus of this period (pages 101-574), and a section of A ppendices (pages 575-695) which correspond to the original subsections of the introduction and offer valuable information about specific thematic searches. As the contributors acknowledge, their work stems from the comedy files

\footnotetext{
${ }^{1}$ For an enlightening description of the field of Digital Humanities, see Burdick et al. (2012, 7ff.).
} 
themselves. The first section "Introduction" comprehends relevant categories or subsections. They start by stating the selection criteria for their corpus, most importantly pointing out questions of genrefor example, why in some cases they have chosen tragicomedies and not comedies alone, their choice of premiere for those plays meant to be performed, or the date of publication for closet dramas or for which there is insufficient evidence. That produces a substantial corpus of ninety-seven plays for the period covered in the volume, though some specific subsections pay attention to other prefaces and prologues of lost plays which have been left outside the corpus. This neat explanation devolves an image of the very efficient preliminary work done on the corpus, certainly one of the greatest achievements of the contributors. The rest of the sections reveal important data which analyze the resulting information of computer searches and database work.

Thus, in “TitlePages," María Jesús Pérez-Jáuregui includes staging details such as the number of plays performed by any of the two patent companies, or information about the growing popularity of mottos, but the diminishing reliance on ornaments or vignettes, in comparison to the previous decade. Intricate and fascinating details about play performance are facilitated by Paula de Pando in the subsection "Performances," where she draws interesting conclusions like the short-lived presence onstage of most Restoration comedies, or the company responsible for the most successful ones. Other relevant details appear in "Publication," by Nora Rodríguez-Loro, such as the average number of plays printed yearly, suggesting that more appeared in the early 1670s and fewer did from 1679 onwards. In "Prefatory matter," María José Mora and Ángeles Tomé Rosales reveal that almost all of the plays include either a prefatory address or a dedication to the reader. The kind and nature of dedicatees suggest that patronage was still prevalent in this period, though some changes were enforced, as unusual dedications prove. The contributors point out that the dedicatory epistles reflect partisan strife, in a clear anticipation of the political events to come. Furthermore, they also claim that in prefaces authors often discuss dramatic theory or engage in the poets' wars. They discover that prologues and epilogues become a rule in this new decade, appearing in the $97 \%$ of the plays produced. They also observe that the number of women delivering the prologues increases to $25 \%$ from almost zero in the previous period. 
In "Dramatic Structure," Manuel J. Gómez-Lara concludes that as the location of scenes is concerned, London continues being the most popular setting for the plays, though other distant cities are also included. He also argues that there is not much change with respect to the treatment of the three dramatic unities. In "Genre," Jorge Figueroa Dorrego carries out the difficult task of generic classification. He makes an effort to assign each play to a specific generic type, and in so doing, he distinguishes among ten categories, the most popular of which are the comedy of intrigue, sex comedy, satirical comedy and farce, a distinction made according to the dominant plot and characters in the play. ${ }^{2}$ As Figueroa Dorrego admits, though, the attribution of some plays to a single generic category is a controversial point. Juan A. Prieto-Pablos systematizes in "Characters" the heading as well as the description types, which he reduces to three, out of which type 2, including one or two further details like age, provenance or family relations to the customary nameand title, stands out as the prevailing description in half of the plays. Type 3, featuring details of personality and behavior, was also very popular, since it is found in some 32 comedies. Prieto-Pablos establishes a typology comprising six basic types, resembling very closely the one devised for the first volume in the series: gallants, women of quality, blocking characters, helpers, comic butts, and cheats, with further distinctions for each type. This is a very useful classification in the whole, though it also make us wonder about the criteria used to define them, as some of them seem to be described according to personality, like women of quality, and others according to their dramatic (or narrative) function, like blocking characters and helpers. The contributor comments on some interesting findings, such as the fact that "constant gallants" appear more assiduously in this decade or that blocking characters of the "plotting villain" kind increase in this period, as the logical corollary of the plots and political crisis which were taking place. As might have been expected, many of these categories are heterogeneous, while other types, like "cheats," acquire a category of their own in their classification for the first time. In the next subsection, "Actors," Prieto-Pablos concludes that on average plays

\footnotetext{
2 These are the two categories selected by Brian Corman in his book on genre in Restoration comedies, as being "the most useful and direct means to examine issues of genre and generic change" (1993, xi). It must be admitted, though, that Corman accounts for some eighty-one plays for the whole period of study, while the corpus in Restoration Comedy, 1671-1682 al ready surpasses that number.
} 
contain 13 or 14 individual characters, as did the plays produced in the previous decade. A change is found, however, when approaching the sex of characters and performers. Thus, A phra Behn favors female characters significantly in her plays, but even so, the presence of women is below the company's average. M oreover, data related to the sex of the character, Prieto-Pablos contends, should not be interpreted as a sign of growing gender awareness, since with few exceptions like Behn's works women do not play agentive roles. Progressively, we discover, actors and actresses' names appear in the characters' list, though no explanation for this changeis given. The recurrence of male and female performers in the cast of plays produced by one particular company is stable, and the access of young actors and actresses ends in an exponential growth of the roster. Most of the time, actors and actresses stick to the same character types.

As for "Stage Directions," Manuel J. Gómez Lara and Antonio Rosso claim that they follow the essential dynamics of the previous decade but increase mainly because more plays are intended for the stage. They distinguish five types: references to the acting space, to acting, special effects, props, and non-performative directions, as well as a detailed number of subcategories for each of them. In "Music," Rafael Vélez Núñez studies the presence of music in the chosen decade, which, heclaims, continues being an important element in the comedies. Following the average occurrence of musical turns in this second decade, a high percentage $(91.8 \%)$ of extant plays contain songs; $69.4 \%$ also include dances. As in the former period, dances in particular are concentrated productively in the finale. Last, but not least, in "Sources," María José Mora identifies sources for more than half of the extant comedies in the period, a percentage higher than in the former decade. She explains how sources for comedies are primarily English, especially from Jacobean and Carolean drama, but French sources are also numerous, both from plays and romances or novels, Molière being a favorite by far. Mora argues that this use of foreign sources includes in some cases a second plot more congenial to the English taste. Spanish sources come third in the ranking, with at least nine comedies. Calderón remains the most popular dramatist, while some other Spanish influences come through French versions, 
as in the case of some of Cervantes's stories, María de Zayas' and Castillo Solórzano's. ${ }^{3}$

The most substantial part of the catalogue corresponds to the Comedy Files, which systematize the study of the corpus in a highly efficient way, including the following entries for most of the plays: Title, Author, Publication, Modern editions, Performance details, Preface, Dedication, Prologue, Epilogue, Characters (with the description provided in the printed versions of the plays), Location and Time (including scene divisions and scene locations), Plot summary, Genre, Stage directions, Songs and Dances, Sources and Comments. The plays are alphabetically ordered by author in all cases. The volume concludes with a section of appendices, arranged following the categories specified in the "Introduction": A ppendices 1,2 and 3 on information drawn from title pages, Appendix 4 on performances, Appendix 5 on publication, A ppendix 6 on prefatory matter, Appendix 7 on dramatic structure, Appendix 8 on genres, A ppendix 9 on characters (occurrences following each character type), A ppendix 10 on actors (according to the roles they play, male and female occurrences, and performers for each company), A ppendix 11 on stage directions, Appendix 12 on music (specifying musical pieces), and A ppendix 13 on sources. A final section of References on aspects related to Restoration playwriting, dramatic theory, performance and individual authors is included.

No doubt, this new volume produced by the members of the Restoration Comedy projects is a valuable contribution to the drama of the period, providing important tools for future researchers in the field, as well as shedding light on late seventeenth-century writing as a wholeand on the society and culture of the Restoration, opening the way, for example, for cross-generic and inter-generic analyses, and suggesting that the crossing of data from related categories (and related genres) might yield enlightening results in the long run.

\section{References}

Braga Riera, Jorge. 2010. “The Adaptation of Seventeenth-Century Spanish

Drama to the English Stage during the Restoration Period: The Case of

\footnotetext{
${ }^{3}$ This much could be also affirmed about the prose fiction of the period (Braga Riera $2010,108)$.
} 
Reviews

Cal derón." In Theatre and Culture in Early M odern England, 1650-1737: from Leviathan to Licensing A ct, edited by Catie Gill, 107-18. London: Routledge.

Burdick, Anne, et al. 2012. Digital_H umanities. Massachusetts: MIT Press.

Corman, Brian. 1993. Genre and Generic Change in English Comedy, 1660-1710.

Toronto: University of Toronto Press.

How to cite this review:

Villegas López, Sonia. Review of María José Mora, ed., Restoration Comedy, 16711682 (New York: Teneo Press, 2019). SEDERI 30 (2020): 157-62.

A uthor's contact: villegas@dfing.uhu.es

Postal address: Departamento de Filología Inglesa - Universidad de Huelva - Avda. Tres de Marzo s/ n - 21071, Huelva - Spain 


\title{
Charles N ey. 2019. Directing Shakespeare in America. Historical Perspectives. The Arden Shakespeare. London: Bloomsbury
}

\author{
Víctor Huertas Martín \\ U niversidad de Extremadura, Spain
}

Writing on Shakespearean directing in America is a daunting task. Nonetheless, in recent years, critical works by scholars such as Helene Wickham Koon, Nigel Cliff, Denise Albanese, James Shapiro, Dympna Callaghan and Suzanne Gossett, Katherine Rowe, Alden T. Vaughan and Virginia Mason Vaughan and others on Shakespeare in America have raised scholarly and public interest in sustained examination of the impact of Shakespeare in the USA. Are there specific traces to identify Shakespearean theatrical directing in the USA apart from the fact that the body of recorded productions took place on American soil? Charles Ney proficiently-though not exhaustively-accomplishes the task of presenting clues which help paint the broad picture of directing Shakespeare in A merican theatre with admirable clarity. He does so by starting with a survey of the directors emerging between the 1870s and the 1940s. Then he reviews Shakespearean directors at the Oregon Festival, at the Old Globe, and the New York Shakespeare Festival. He examines the works carried by directors at Shakespeare Festivals and Theatres and, finally, concludes with miscellaneous examples of Shakespearean directors and theatres across the USA.

Ney historicizes the way in which the American theatre industry has mounted and received Shakespeare in the last century and a half. A teacher and a director himself, he takes the emergence of the theatre director in America as his vantage point. Having consulted testimonies, letters, promptbooks, diaries, lectures, academic and newspaper reviews, etc., his methodology consists in explaining the style, prominent features and rationale of most directors' working procedures. Though the book doesn't intend to be steeped in theory, at first sight, he discerns two major tendencies in American theatrical directing of Shakespeare: one intends to serve "the author's voice and intention" and another one embraces "complete artistic freedom in interpretation of the play" (2). After posing this idea, Ney 
attempts to reveal a larger and more complex and nuanced reality. Starting, as said, with the emergence of the theatre director in the US, he reveals the process by which actor-centered artistic policies gave way to director-centered artistic policies in the American theatre. He distinguishes directors definable by their imposing and controlling personalities and those concerned with bringing a respectful and humane approach to directing actors and to interpreting the text. Reading the book, we discover that-though there is room in the USA for directors with strong artistic instinctsA merica's rationale in Shakespearean directing stems from reverence for the text and a series of added principles akin to America's democratic ethos and to the public value that Shakespeare holds in the United States.

Rather than fully describing Ney's book and then looking into the book's results, I will start by highlighting some of such results. As I was reading, I felt that the reader interested in the subject might not only benefit from reading Ney's work alongside other scholarly and historical works on America's Shakespeare, such as Vaughan and Vaughan's Shakespeare in A merica (2012) or James Shapiro's studies on the subject. I also found that, while many sections presented illuminating statements, others tended to privilege summary of what critics and reviews had said over Nay's exposition. Or, at least, exposition seemed to get obscured amidst quotes from reviews whose authors evaluated concrete details of the productions. This does not mean that the book fails. In fact, the findings of Ney's thorough and in-depth research lead to strong points which are worth knowing before reading the book.

From Ney's conclusions, I gather that American directors have been at odds between contemporariness-in its different manifestations-and authenticity when thinking of mise-en-scènes. While varied degrees of interventionism with regards to the plays' interpretations have been identified in directing styles, I infer that a tendency exists to look favorably upon directors who evolve towards deciding to extract what they think lies at the heart of the text, not to rely on "concepts." Thus, evolutionary shifts from concept-based productions towards text-centered productions-balancing director's artistic subjectivity with the author's intentions-seem to appear as natural learning processes. Amongst other evidences that 
Ney seems to lean on this view, we may later on find the way he describes director Michael Kahn's evolution:

[Kahn] matured through his decade working [at the ASF]. A theatrical innovator, he began as a strongly conceptual director, exploring production ideas based on contemporary observations; these became ruling ideas for his powerful evocative productions. When he started directing at AST, all choices were subservient to his concept. [...] As he developed more experience, he let go of the need to impose on the plays. Instead, he sought to reveal what he thought Shakespeare had written. (104)

Also discerned is the fact that directors tend to privilege rapid delivery, speed, physicality, and clarity in performers and that their treatment of actors is also a mark of directorial styles as relevant as stylistic choices. As a matter of fact, a relationship seems to be implicitly established between the way actors are treated and the way texts and author are treated. The volume also appraises the way in which American actors' performances shine whenever their own qualities-athleticism, hard-working habits, ethnic diversity, tendency to realism, etc.-are preferred to the "gloss" of British or European acting conventions. Thus, one may interpret the book, alongside other scholarly works on Shakespeare in A merica-such as the recent James Shapiro's Shakespeare in a Divided America (2020) - as a history of reception of Shakespeare going hand in hand with A merica's sometimes tortuous processes of democratization.

Reading the chapters, such key principles seem to naturally unfold while reading Ney's thorough account. Starting with early directors like August Daly, David Belasco, Arthur Hopkins, Orson Welles, and Margaret Webster, we notice a tendency to privilege erudite but clean, play-centered, gimmick-free, uncluttered, technically proficient, and innovative productions whether such productions embrace naturalistic, pictorial, iconoclastic styles across varied constituencies, public or commercial.

The next two chapters-two and three, on the Oregon Festival and on the Old Globe-study Iden Payne, Angus Bowmer, Jack O'Brien, Tyrone Guthrie, and others. Describing Payne's modified Elizabethan approach, inherited from Sir William Poel, Ney associates the American tradition with a British theatrical model which is adapted for the architecture of the US venues. Indeed, Payne extends the Elizabethan model, establishing stage zones of 
influence to facilitate rapid successions of scenes and defining diverse uses for curtains to augment such speed in the transitions. Free air productions-akin to ritual and overt theatricality-and the director's humility and capacity to learn from others are also highlighted as values in the profession. Continuing through chapters four and five - on American Shakespeare Festival and on The Public Theater-N ey examines the above-mentioned Kahn's trajectory and proceeds to examine John Houseman, Jack Landau, Gerald Freedman, Peter Coe and, importantly, Joseph Papp, creator of The Public Theater, and his successors. Together, these artists progressively move away from the psychologically burdensome "acting method" in favor of language and text and of a democratically-oriented ethos to disseminate Shakespearean performances amongst a diverse public. The sixth and seventh chapters, on festivals and on varied theatres and directors, reveal the quantitative increase of Shakespearean performances in America in the last few decades. Contributions by Kahn-at the Folger Shakespeare Company-, William Ball, Liviu Ciulei, Garland Wright, Mark Lamos, Ellis Rabb, or Julie Taymor are examined. Again, it is noticeable that freedom from the shackles of concept, preference for energetic, vivid, rapid and physical performance lead to interpretations that often-as in the case of Mark Lamos' $\mathrm{H}$ amletrun against the grain of received interpretations. Pluralistic ethnicity and accomplished performance are preferred to concept. Nonetheless, distinct theatrical and aesthetic techniques such as those deployed by Ciulei and Taymor have their own place, as the book reveals, in this rapid development of American Shakespeares.

Ney's work is to be recommended, making a pleasant and informative reading. Rich in detail and with a taste for carefully arranging specificities in logical and organic ways, the volume reveals trends defining director's Shakespeares in America. A priceless document for scholars interested in theorizing Shakespearean performance in the USA, it reveals the fertile American theatrical tradition as a basis on which to broaden our perspectives on the significance of Shakespeare-not just as performance, but as a series of texts and their critical histories-in American popular and public culture. For literary scholars and adaptation scholars, the book rethinks concepts such as faithfulness or fidelity to author's intentions or to text, ideas which are normally looked upon with suspicion in these fields, suggesting the 
(5) ederi 30 (2020)

exploratory eagerness of directors and actors to intensely and passionately read rather than to pigeonhole the texts.

How to cite this review:

Huertas Martín, Víctor. Review of Charles Ney, Directing Shakespeare in A merica. H istorical Perspectives (London: Bloomsbury, 2019). SED ERI 30 (2020): 163-67.

A uthor's contact: cuccioli25@hotmail.com

Postal address: Dpto. Filología Inglesa - Universidad de Extremadura - Avda. Universidad, s/ n. - 10003 Cáceres - Spain 



\title{
Patricia Parker. 2018. Shakespearean Intersections: Language, Contexts, Critical Keywords. Philadelphia: University of Pennsylvania Press
}

\author{
Zenón Luis-Martínez \\ U niversidad de H uelva, Spain
}

Published over twenty years after Shakespeare from the M argins (1996), Patricia Parker's new book, Shakespearean Intersections, brings a highly anticipated sequel in which the paths and crossroads transited in the former volume take the form of unforeseen revisitings and unexpected bifurcations. Between these two extraordinary books, a series of articles and book chapters (see 2001, 2002, 2003, 2004, 2008, 2013), witness to Parker's commitment to her unique approach to Shakespeare's texts. The more than four hundred pages of Shakespearean Intersections-eighty of which are of copious, learned endnotes-give little room to the explication of a methodology that demands from readers a habituation to Parker's characteristic critical idiom and a substantial training in literary theory, Shakespearean criticism, and early modern studies. The book's subtitle — Language, Contexts, Critical Keywords-replicates two terms from the former volume's-Language, Culture, Context-in a clear gesture of continuity. Both the similarities and differences between these subtitles are significant for clarifying Parker's renewed confidence in her distinctive philological practice as an analytical tool that unsettles received assumptions of genre, gender, sexuality, history, and politics in the Shakespearean text. As for similarities ("language," "contexts"), the concision with which Parker states her thesis in Shakespearean Intersections is inversely proportional to the rewards of her critical practice: in Shakespeare's plays, she asserts, "the boundary between language and context is an incontinent divide" (2). Unfolding the encounter of a verbally and ideologically uncontained Shakespearean text with its plural, multilingual early modern contexts has been the aim of Parker's lifelong dedication to Shakespeare studies. Shakespearean texts do not merely reflect their early modern contexts, and those contexts do not comfortably frame the texts. Rather, texts and contexts overflow each other incessantly, stretching Shakespeare's linguistic uses across changing semantic fields, unstable genre conventions, and 
multiple tongues. Echoing scholars like Martin Jay (1998), Parker has elsewhere labelled her method "cultural semantics" (2002). For Parker, the fertile instability of the Shakespearean text is manifested through intricate networks of spellings, pronunciations, collocations, puns, compounds, translingual etymologies, and multilingual intersections. Words do not interpenetrate one another only within the protean dramatic genres of Shakespeare's England. Their semantic quaintness resonates in a rich textual web of literary, rhetorical, moral, historical, political, economic, and religious discourses whose signifiers and referents permeate Shakespeare's practices of naming, characterization, and dramatic design. Attention to these complexities paves the way to a critical practice that turns inside out some of our most confident assumptions about the plays.

Yet Parker's novel use of "critical keywords" validates her method beyond the mere accretion of additional evidence to support old themes in her work. Following the lead of materialist critic Raymond Williams's Keywords: A V ocabulary of Culture and Society (1976), Parker joins the efforts of other recent early modernistsGreene (2013), Mac Carthy (2013) - in their conviction that "important social and historical processes" are shown to "occur within language" $(1976,22)$. In the introductory essay to Mac Carthy's collection, Richard Scholar argues for the need to add to this aim a sensitivity to the complex webs of contradictory cultural notions occurring across the languages of Renaissance Europe. Scholar invokes, among others, Edward Said's epitome of the philological virtues of "reception" and "resistance," combining our accruing of the cultural and historical heritage stored in words with a practice of a "para-doxal mode of thought," always alert to critical questionings of received knowledge (Scholar 2013, 8; Said 2004, 83). Parker's practice in Shakespearean Intersections is exemplary of this much needed commitment to renewed philological methodologies in early modern studies.

Beyond acknowledged affinities, Parker's Introduction does not claim her choice of words to be "key" or essential for the interpretation of Renaissance culture. Rather, their value as keywords is granted by the adjective "critical": these words "are chosen from the language of particular plays themselves" in order to work "as a heuristic methodology for particular critical analyses and 
interventions" (1). Thus, they offer a critical portal into the contexts of the plays, along with "issues and historical intersections that have been marginalized or have gone unnoticed by their editors and critics" (1). Initially, the list of words might seem capricious: terms like "arsy-versy," "awkward," "breach," "change," "cashier," "incontinence," "latter end," "suppose," "quince," or "preposterous," and proper names like "Brabant," "Low Countries," or "Ganymede" may have a more or less iterative presence in Shakespeare's work either in the quoted forms here or in their participation in intersectional semantic fields. Yet, in their shared marginality, these words construct a powerful network illuminating forgotten or consciously ignored corners of Shakespearean meaning with profound repercussions to our understanding of the plays. Of these words, "preposterous" comes foremost as "the most pervasive "keyword' in this book" (9-10). Its suggestions of spatial and temporal transposition, as well as its association with the rhetorical figure of hysteron proteron, enable Parker's scrutiny of the word's conceptualization of multiple forms of inversion including historical chronology, typological structures, biological life, familial lineage and inheritance, socioeconomic order, political hierarchy, sexual identities and practices, rhetorical and social propriety, as well as generic prescriptions and expectations-namely, beginnings, middles, and ends in relation to tragedy, comedy, and mixed genres. Preposterousness fosters an alternative Shakespearean poetics, while a critical practice sustaining its ubiquity in the plays recommends attention to a set of words that other methodologies would condemn to insignificance.

Parker's choice of plays in Shakespearean Intersections, not entirely new to her work, observes a careful arrangement. In what is perhaps the book's only nod to critical correctness, Parker's narrative thread proceeds by genre: Love's Labour's Lost (1594), The Taming of the Shrew (1592) and A M idsummer N ight's D ream (1596) occupy the first three chapters on comedy; Henry V (1599) in the context of the serial history plays is the subject of chapter 4; tragedy is represented by 0 thello (1604) in chapter 5; finally, tragicomic romance is served by Cymbeline (1610) in chapter 6. With the exception of the inverted order in the first two chapters, Parker is also observant to received Shakespearean chronology. Surprising as this may sound in a book so insistent on unsettling temporal structures and lineal orders, this procedure may reveal further subtexts. Although Parker shuns 
explicit biographical narrative or claims to authorial intention, an effect of reading Shakespearean Intersections lineally is an implicit conviction that Shakespeare's knowledge, art, and ideological concerns develop by accumulation of authorial experience.

Parker's analytic procedure combines, in her own words, varying ratios "of attention to language, contexts, and close reading" (2). A balance between these three areas of interest is more rationally observed in the three chapters on comedy opening the book. Chapter 1, "Preposterous Reversals, Latter Ends: Language and Contexts in Love's Labor's Lost" starts on Armado's accusation of Costard's affair with Jacquenetta, which he defines as an "obscene and most prepost'rous event" (1.1.241-42), to argue that the play's preoccupation with the "preposterous," "backward," and "arsyversy" runs counter to a critical tradition that has marginalized its bawdy and scatological subtexts for the sake of a civilizing idea of comedy (32-33). Tracing the word's presence in manuals of orthography, rhetoric, and multilingual dictionaries, Parker reads the play's rich textures of linguistic and sexual inversion, such as the incontinence of its verbal riddling, which transmutes enigmas into "egmas," or enemas (3.1.71); or the calling of Holofernes "Jud-ass" (5.2.628), which plays with current associations of Jews with sodomy; or the references to "latter ends" as tropes for the openendedness of a comedy, whose implicit deviancy exorcises romantic expectations of heterosexual marriage. Cueing on similar arguments, Chapter 2, "Mastering Bianca, Preposterous Constructions and Wanton Supposes: The Taming of the Shrew," challenges the critical tradition that presents Bianca as a potentially tractable maid, particularly through the use in Lucentio/ Cambio's mock Latin lesson of Penelope's complaint about Ulysses' failure to return home in Ovid's Heroides, which projects a view of wifely behavior that is "anything but submissive" (91). Parker's detailed analysis of the play's intimations of sexual deviancy also looks into the language of backwardness in "backare" (2.1.73) and fiddling in relation to Lyly's M idas (1592) (106-109), or the Bianca plot in relation to its multilingual source in A riosto's comedy I Suppositi (1509), translated by George Gascoigne as Supposes (1566), whose original paratext plays on the sodomitical senses of "supposition" (113-22).

Chapter 3, "Multilingual Quinces and A Midsummer Night's D ream: Visual Contexts, Carpenters' Coigns, Athenian Wedding" 
defies the tradition that has associated the name of Peter Quince exclusively with carpenters' coigns-an issue that Parker had examined elsewhere (1996, 83-115). Noting previous editorial failure to find in Quince's name resonances of the fruit that it designates in English, Parker embarks on a fascinating philological excavation of the word's meaning and connotations in classical and modern languages, as well as the rich textual tradition associating the quince with marriage and fertile sexuality, but also with deviant forms through dizzying intimations of swelling organs and open tracts. Attention to a rich emblematic tradition and to the influence of Plutarch's Conjugal Precepts (129-42) reopens the issue of Shakespeare's sources for the D ream, signaling the way to necessary editorial revisions. Her method shines here at its most resourceful and fruitful in terms of the rewards that we traditionally expect from outstanding literary scholarship: a cornucopia of positive, material evidence at the service of persuasive explications of the seldom straightforward courses of the best literary texts.

The move to other genres in the second half of the book shifts emphasis from close reading to contextual analysis. Chapter 4, "'No Sinister Nor No Awkward Claim': Theatrical Contexts and Preposterous Recalls in Henry $V$, , begins at the play's end by invoking its Folio epilogue as the inception of a narrative that simultaneously looks forward into English history and backwards into Shakespearean chronology. Parker argues that recent work on memory in the histories tend to neglect the fact that for London theatregoers the memory of $\mathrm{H}$ enry $\mathrm{V}$ lay preposterously in the historical future of the earlier $\mathrm{H}$ enry VI plays and Richard III as much as it did in Richard II and the two parts of Henry IV. The epilogue's deflating rhetoric stresses the play's faultlines by reference to the first tetralogy. A small-scale approach to significant keywords, echoing Exeter's disclaimer of the "sinister" and "awkward" quality of Henry's dynastic rights to France through female descent (2.4.85), as well as the rhetoric of "marches" and "borders" that serves to contrast Henry's rights to the English throne in opposition to the stronger Mortimer claims suppressed in the Cambridge rebellion, points to a complex narrative of familial and political breaches whose "preposterous recalls" in the Henry VI plays compromise sequential order as the basis for heroic notions of history. 
Chapter 5, "What's in a Name? Brabant and the Global Contexts of 0 thello," replaces interest in the English past with contemporary history leading from the play's traditional focus on EuropeanOttoman conflict around Cyprus to Spanish-Dutch-English wars throughout the sixteenth century by reference to the Spanish devil/ saint "Iago," and the Spanish N etherlands evoked through the "Brabant" that previous criticism has failed to associate with Desdemona's father, Brabantio. Parker's reconstruction of sixteenthcentury warfare contexts through the presence of Brabant in European and English military history is an exemplary exercise in archival research and philological acuteness. One could object that context in this chapter almost entirely swallows the play. Yet Parker's focus on the relevance of Brabant as an "alarum" prefiguring the Armada episode certainly resonates in the "alarums" for Turkish wars in 0 thello in the context of the frequent conflations of Spaniards and Turks found in sixteenth-century English texts. The ultimate reasons for Shakespeare's name Brabantio project 0 thello beyond its plot into "extended global context [...] without having to entail any literalistic one-to-one-to-one relation with the character himself" (258).

Contemporary local history also presides over a final chapter, "Intimations of Ganymede in Cymbeline," which works both as a recapitulation of the book's concerns and as a companion piece to Parker's recent work on this play (Parker 2013). Beginning in a sort of nothing-up-my-sleeves maneuver that seeks to demonstrate the pervasiveness of a name in a play in which it never appears, Parker argues that "Ganymede" enters Cymbeline in the spectacular scene of Posthumus' dream presided over by lupiter's descent "sitting upon an eagle" (5.5.91). Yet this ghostly entrance at the end of the play has been preceded by the earlier suggestion of Posthumus as a Ganymede figure "raised" by Cymbeline in a gesture that evokes King James's "raising" of his favorites Robert Carr and James Hay. Reading through literary and emblematic sources on Jupiter's rape of Ganymede (Drayton, Spenser, Peacham, Beaumont and Fletcher), Parker reconstructs the play's breach of the homo/ hetero divide in its representation of the cross-dressed Innogen as Fidele, and more particularly in its re-elaborations of the ring plot of The $M$ erchant of Venice (1596). Replicating this interest in preposterous venery, Cymbeline builds up a preposterous time in which invasion and peace negotiations speak to James's controversial peace with Spain 
in 1604, thus compounding "a temporal palimpsest" of ancient and contemporary histories around British-European conflicts (296-97).

Numerous other critical narratives that fall out of the scope of this review run through the winding circulatory system of Shakespearean Intersections, a book whose festive tones and often mischievous topics are never at odds with its admirable learning and rigor. Her witty, consciously iterative prose, in which keywords and key phrases reappear with the formulaic persistence of an epic poem, parallels Shakespeare's own penchant for restatement. A lively reminder to early modernists of how much our contextual explanations may gain from attention to the details of language, Parker's magisterial close readings of Shakespeare make of her critical writing a genre in its own right: Shakespearean Intersections is to this date its most accomplished exemplar.

\section{References}

Greene, Roland. 2013 Five Words: Critical Semantics in the A ge of Shakespeare and Cervantes. Chicago: The University of Chicago Press.

Jay, Martin. Cultural Semantics: Keywords of Our Time. Amherst, MA: University of Massachusetts Press.

Mac Carthy, Ita, ed. 2013. Renaissance Keywords. London: MHRA/ Legenda.

Parker, Patricia. 1996. Shakespeare from the Margins: Language, Culture, Contexts. Chicago: University of Chicago Press.

Parker, Patricia. 2001. “What's in a Name: And More." SE D ERI 11: 101-49.

Parker, Patricia. 2002. "Preposterous Conversions: Turning Turk and its 'Pauline' Rerighting." Journal for Early M odern Cultural Studies 2: 1-34.

Parker, Patricia. 2003. "Black Hamlet: Battening on the Moor." Shakespeare Studies 31: 127-64.

Parker, Patricia. 2004. "Barbers and Barbary: Early Modern Cultural Semantics." Renaissance D rama (N ew Series) 33: 201-44.

Parker, Patricia. 2008. "Cutting Both Ways: Bloodletting, Castration/ Circumcision, and the 'Lancelet' of The M erchant of Venice." In A Iternative Shakespeares 3, edited by Diana E. Henderson, 95-118. London: Routledge.

Parker, Patricia. 2013. “Cymbeline: Arithmetic, Double-Entry Bookkeeping, Counts, and Accounts." SEDERI 23: 95-119.

Said, Edward. 2004. "The Return to Philology." In H umanism and D emocratic Criticism, 57-84. New York: Columbia University Press. 
Scholar, Richard. 2013. "The New Philologists." In Renaissance Keywords, edited by Ita Mac Carthy, 1-10. London: MHRA/ Legenda.

Shakespeare, William. 1987. The Riverside Shakespeare $2^{\text {nd }}$ ed. Edited by G. Blakemore Evans. Boston: Houghton Miffin.

Williams, Raymond. 1976. Keywords: A Vocabulary of Culture and Society. London: Fontana Press (revised ed. 1988).

How to cite this review:

Luis-Martínez, Zenón. Review of Patricia Parker, Shakespearean Intersections: Language, Contexts, Critical Keywords (Philadelphia: University of Pennsylvania Press, 2018). SEDERI 30 (2020): 169-76.

Author's contact: luis@dfing.uhu.es

Postal address: Departamento de Filología Inglesa - Universidad de Huelva - Avda. Tres de Marzo s/ n - 21071, Huelva - Spain 


\title{
Ángel-Luis Pujante. 2019. Shakespeare llega a España: I/ustración y Romanticismo. Boadilla del M onte: A. Machado Libros
}

\author{
Jesús Tronch \\ U niversitat de $V$ alència, Spain
}

Regular readers of SEDERI do not need an introduction to ÁngelLuis Pujante, emeritus professor of English at the Universidad de Murcia, and, among other merits, the scholar of reference on the study of the presence of Shakespeare in Spain. The latest attestation to this statement is the book under review, Shakespeare Comes to Spain: Enlightenment and Romanticism, a Spanish-language, 374-page essay that thoroughly examines the early reception of Shakespeare's work in Spain, from the early folios of his plays that reached these latitudes in the seventeenth century until the 1840s. While in previous book-length studies, Pujante collaborated with colleagues from Murcia, such as Laura Campillo, Juan Francisco Cerdá, and Keith Gregor, this monograph is a single-handed venture (like his book EI manuscrito shakespeariano de Herrera Bustamante [2001]), and, instead of focusing on a single play ( $\mathrm{H}$ amlet, $\mathrm{M}$ acbeth, Romeo and Juliet) or on writings on Shakespeare, this essay offers a comprehensive analysis of criticism, translations, adaptations, and theatre productions, the most conspicuous areas in which the cultural reception of a dramatist in a different country and/ or culture can be studied. A precedent can be found in Alfonso Par's 359-page first volume of his Shakespeare en la literatura española (1935), covering the periods "Galoclasicismo" and "Romanticismo," combined with the first volume of his catalogue of theatre productions in Representaciones shakespearianas (1936). Preceded by a preliminary note and introduction, seventeen dense chapters (with suggestive titles) offer both an in-depth survey, in chronological order, of how Shakespeare was received and accepted in the abovementioned areas of Spanish culture, and a critique of the central problems this kind of study has involved. As Pujante clearly states early in his book, he does not shrink from correcting previous scholars' wrong interpretations or inferences (including himself and 
the author of this review), and exposing their errors (8): for instance, he corrects the view that the earliest Shakespeare-related performance, the $1772 \mathrm{H}$ amleto, and the 1838 production of $\mathrm{M}$ acbeth were a fiasco $(50,236)$, and rectifies the misattribution to José Cadalso of a pamphlet, written by Rubín de Celis, that mentions this $\mathrm{H}$ amleto $(49,289)$. What empowers him to do so is his balanced and non-partisan attitude and his rigorous method, characterized by refusing gratuitous speculation, consulting sources directly (from libraries in Spain, France, United Kingdom, Germany, and Austria), painstakingly contrasting assumptions against evidence, and patiently comparing translations with their originals and explaining their differences. As expected in a comprehensive study like this, a good number of chapters are based on, or reuse findings in, Pujante's previous research, which he duly acknowledges.

The Introduction (chapter 2) summarily anticipates the general lines in which the early reception of Shakespeare in Spain can be drawn: in the eighteenth century, Spanish critics became interested in Shakespeare as an element of a French debate over the preeminence of neo-classicism in the Spanish controversy between classicists advocating the aesthetics of Corneille and Racine and traditional ists vindicating the dramatists of the Golden Age. Spanish views of Shakespeare did not fall prey to the Anglomania observed in French circles, and in the nineteenth century, the emergence of Romanticism and liberalism led to the paradoxical phenomenon, exclusive to Spain, of conservatives being Romanticists while liberals were classicists, some of whom, after their exile from Spain, embraced Romanticism and championed Shakespeare.

In chapter 3, Pujante expresses his skepticism as to the existence of a First Folio in the library of Count Gondomar (Spanish ambassador in England between 1613 and 1622) and ventures a hypothesis as to why the Arabist Pascual de Gayangos made up the story of the First Folio he claimed to have seen in Valladolid (29). In chapters 4, 6, 7 and 9, Pujante explains the uses of Shakespeare among Spanish men of letters in the eighteenth century, echoing Voltaire's criticism of Shakespeare's vices and virtues and reflecting the tensions that characterized the early dissemination of Shakespeare in Europe through France: Francophilia and Anglomania, and the rules of classicist French drama versus their disregard by English and Spanish playwrights, later advocated by 
Romantic aesthetics. Thus, in 1764 Francisco Mariano Nifo partially used Voltaire in order to disapprove of the way Shakespeare was performed in France and to oppose the classicist rules, while later in the century exiled Jesuits relied on Voltaire to attack Shakespearean dramaturgy in their treatises. Chapter 9 elucidates the implications that Hugh Blair's influential Lectures on Rhetoric and Belles Lettres had in the Spanish and European reception of Shakespeare by a close analysis of the original and the Spanish translations. Chapter 5 focuses on the four versions of $\mathrm{H}$ amlet that derive from Jean-François Ducis's "imitation," attending to both formal and ideological issues; and chapter 8 on Leandro Fernández de Moratín's complete and direct translation of this tragedy, clarifying its contradictions, revealing how Moratín took some translation solutions from the French translation by Le Tourneur (105), and qualifying the result as "flat" in comparison with the stylistic variety of the original and without the latter's subtleties, ironies, and wordplay (106).

As expected, the nature and quantity of the primary material available determines that more chapters are devoted to Shakespeare in criticism than as translated and performed. Half of the remaining nineteenth-century chapters (10,14, 15, 16 and 19) deal with critical views on Shakespeare. In them Pujante details continuities articulated around the Voltaire-derived notions of vices and virtues, natural genius and art, most in the context of debates between classicist and Romantic positions, and traces the gradual acceptance of Shakespeare's dramaturgy until his position became consolidated once Romanticism took hold in the late 1830s, a trajectory that was immersed both in aesthetics and in politics. As a number of pieces of criticism are translations or are derived from English, French, and German sources, Pujante brings to light even "tendentious conceptual manipulations" (178) that serve the critic's own agenda (for instance, Böhl de Faber translating Schlegel's criticism). Two chapters, 15 and 16, center on exiled liberals such as José Joaquín de Mora and José Blanco White, about whom Pujante agrees with modern critics that deplore the comparatively slight impact of his fascinating, high-quality oeuvre (223).

The remaining chapters deal with Spanish Shakespeares in performance and translation, particularly 0 thello, Romeo and Juliet, Richard III, and M acbeth. Until 1838, they were all versions of French originals. Pujante enlivens his analyses by paying attention to their 
political resonances and paradoxes without losing sight of the European connections. Ducis's "imitation" of 0 thello was translated by Teodoro La Calle, a liberal who nonetheless diluted the allusion to the French revolution in a translation for which Pujante does not spare qualifications such as "mediocre or pedestrian" and "not rigorous" (132). A parody of this Otelo, entitled Caliche 0 el tuno de $M$ acarena, first published in 1823, benefitted from, and at the same time, reinforced the popularity of Shakespeare's tragedy, an "Otelomania" that contributed to the strengthening of Shakespeare's presence in Spain even when this play was not directly translated from Shakespeare (141-42). García de Villalta reflects his liberal ideology in his "free translation" of M acbeth by using the term "tirano" [tyrant] sixteen times, as opposed to nine in the original, and by emphasizing the consequences of Macbeth's usurpation and tyranny more than they are in Shakespeare (249).

Published by A. Machado Libros, the monograph is number 55 in a series that combines essays with fiction and drama, with authors such as Ernst Bloch, Sinclair Lewis and Sergi Belbel. This context might explain Pujante's strategy of selectiveness in his focus on central problems in the main body of the chapters, and copiousness in the detailed endnotes (8), as well as his amenable and fluent style, with vocabulary attuned to the non-specialist in Shakespeare, and with quotations from French, English, and German sources translated into Spanish (with the originals available in the corresponding endnote). In a lengthy study such as this one, an occasional slip is almost inevitable (for instance, Henley for Heylen on page 291 and 367), and an index of names and titles like the generous one provided (361-74) is very helpful. This index somewhat compensates for the absence of a final bibliography, which would have made finding full bibliographic details easier: the endnote system proves awkward when the same source is referred to in different chapters (e.g. Pemble from note 13 on page 314).

To conclude, Pujante's Shakespeare llega a España is certainly a "must read" for those studying the presence of Shakespeare in Spain. In many respects, it supersedes Par's first volumes (1935 and 1936) while offering a sound examination of evidence and problems without the biased perspective often observed in Par. For those working on intercultural reception in general, Pujante's monograph can be recommended for his methodological rigor and transnational 
approach, as this study "shows the extent to which Spanish Shakespeare is European Shakespeare from its inception" (Calvo 2009, 946).

\section{References}

Calvo, Clara. 2009. "Shakespeare in Spain: Current Research Trends." Literature Compass 6 (2): 942-56. https:/ / doi.org/ 10.1111/ j.17414113.2009.00647.x.

Gregor, Keith, and Ángel-Luis Pujante. 2011. Macbeth En España: Las V ersiones N eoclásicas. Murcia: Editum Ediciones Universidad de Murcia.

Par, Alfonso. 1935. Shakespeare en la literatura española. 2 vols. Madrid: Librería General de Victoriano Suárez; Barcelona: Biblioteca Balmes.

Par, Alfonso. 1936. Representaciones shakespeareanas en España. Vol. 1: Época galoclásica, época romántica. Madrid: Librería General de Victoriano Suárez; Barcelona: Biblioteca Balmes.

Pujante, Ángel-Luis. 2001. El manuscrito shakespeariano de Manuel Herrera Bustamante. Santander: Sociedad Menéndez Pelayo.

Pujante, Ángel-Luis, and Juan Francisco Cerdá. 2014. Shakespeare in Spain: A n A nnotated Bilingual Bibliography. Murcia: Ediciones de la Universidad de Murcia; Granada: Editorial Universidad de Granada.

Pujante, Ángel-Luis, and Keith Gregor. 2010. Hamlet en España: Las cuatro versiones neoclásicas. Salamanca: Ediciones Universidad de Salamanca; Murcia: Editum Ediciones-Universidad de Murcia.

Pujante, Ángel-Luis, and Keith Gregor. 2017. Romeo y Julieta en España: Las versiones neoclásicas. Murcia: Universidad de Murcia; Madrid: Universidad Complutense de Madrid.

Pujante, Ángel-Luis, and Laura Campillo, eds. 2007. Shakespeare en España. Textos 1764-1916. Granada: Universidad de Granada; Murcia: Universidad de Murcia.

How to cite this review:

Tronch, Jesús. Review of Ángel-Luis Pujante, Shakespeare llega a España: Ilustración y Romanticismo (Boadilla del Monte: A. Machado Libros, 2019). SEDERI 30 (2020): 177-81.

A uthor's contact: jesus.tronch@uv.es

Postal address: Dep. Filologia Anglesa i Alemana - Universitat de València - Av. Blasco Ibáñez 32 - 46010 València - Spain 



\title{
Performance ReVieWs*
}

\author{
West Side Story (2018-2020) \\ Produced by Som Produce \\ Teatro Calderón, M adrid, 22 D ecember 2018 \\ Teatre Tívoli, Barcelona, 14 February 2020
}

\author{
Víctor Huertas-Martín \\ U niversidad de Extremadura, Spain
}

\section{CAST AND CREATIVE TEAM}

\begin{abstract}
Cast: Talía del Val (Maria), Javier A riano (Tony), Silvia Álvarez (A nita), Víctor González (Riff), Oriol Anglada (Bernardo), Enrique del Portal (Doc/ Glad Hand), Diego Molero (Schrank), Carlos Seguí (Krupke), Guido Balzaretti (Chino), Joana Quesada (Pauline [A nybody's] ${ }^{1}$ ).

Jets cast: Alejandro Fernández (Mike [Diesel]), Miguel Ángel Collado (Jack [Action]), Ernesto Pigueiras (Ian [A-Rab]), Axel Amores (Artie [Snowboy]), Nil Carbonell (Baby John), Julia Pérez (Minnie), Maite Fernández (Velma), Gimena González (Grazziella), Julia Saura (Clarice).

Sharks cast: Teresa Ferrer (Rosalia), Lucía Ambrosini (Consuelo), Estefanía del Pino (Teresita), María Martín (Margarita), Marta Torres (Francisca), Daniel Cobacho (Pepe), José Antonio Torres (Indio), Adrián García (Toro), Gustavo Núñez (Luis).

Director /Choreographer: Federico Barrios.
\end{abstract}

\begin{abstract}
${ }^{*}$ Sederi Y earbook collaborates with www.ReviewingShakespeare.com, the first website devoted to scholarly reviews of and writing about worldwide Shakespearean performance (theatre, film, TV) for a general audience. Reviews about Shakespearean performances worldwide submitted for publication to the Sederi Yearbook are sent to the team of specialists managing ReviewingShakespeare, and they will decide whether the review might also be suitable for publication on their webpage. Inversely, a selection of reviews of Spanish and Portuguese productions of Shakespeare's plays submitted to ReviewingShakespeare are also considered for publication in Sederi.
\end{abstract}

${ }^{1}$ In brackets names appear as in the original text by Arthur Laurents. 
A dapters: David Serrano and Alejandro Serrano

M usical D irector: Gaby Goldman

Stage D esigner: Ricardo Sánchez Cuerda

On 3 October 2018, the Teatro Calderón (Madrid) opened to audiences flocking to see West Side Story. I attended two performances: one in Madrid; later, another one in Barcelona. In both cases, the curtain was forged as an urban steel fence: a threshold between reality and story world. Attached to the proscenium in blood red, the play's title, both an announcement and a warning that, beyond the curtain, the territory was hostile. During the preshow, spectators could look through the asymmetrically arranged lattice and see the Jets, closely watched by the police, invigilating their territory on a hot summer evening. As the overture started, Bernardo (Oriol Anglada) entered carrying an object wrapped in a piece of red cloth. Later, we would discover that the object was Bernardo's gun, used by Chino to shoot his rival Tony. Before the play's tragic end, during Lieutenant Schrank's rendez-vous with the Jets after their "War Council" with the Sharks, the policemanplayed by Diego Molero, an agent of authority, counterpart to Prince Escalus-used his gun to bully the Jets, who refused to reveal the whereabouts of their upcoming rumble with the Sharks. Back to this opening scene: Bernardo hid the object to the right of the proscenium. As he felt the Jets approaching, he took off. The Jets entered the stage, but the originally lively music of the "Prologue," started with a more somber mood and a slower pace than usual. When the play concluded, the procession in which Jets and Sharks carry Tony's dead body together was cut and the play finished with Tony's death, Maria's lament, and a circle of impotent spectators around them. This was, once again, WSS, but the world was a much more violent, less innocent, more traumatic place than we thought it was when the world first saw it on stage in 1957 and later, in 1961, on screen.

A uditions for Som Produce's W SS were announced in early 2018 and the show was produced in record time. Unlike other musical theatre companies, Som rethinks musical plays from scratch (although, following contract requirements, the choreography and score need to be respected). Directed and choreographed by Federico 
Barrios, the production toured through Spain and concluded while on tour in March 2020 as a consequence of Covid-19.

The pre-show publicity capitalized on two main ideas. Firstly, the production's blog didn't fail to inter-connect Som's première with the film's earlier Spanish cinematic première in 1963, a time in which, despite the dictatorship, the emerging entertainment and tourist industries were gaining ground and anticipated emancipation and freedom. WSS, this seemed to be the suggestion, meant that in the Spanish sixties there was, as one of WSS songs says, "a place for us [...] somehow, someday, somewhere." Som's transmedia materials took this political reading as a vantage point. In fact, Talía del Val, who played Maria, affirmed that the play-and her own part-endorsed feminist and emancipatory values. A history of continuity between the 1963 event and Som's première was suggested.

Besides, the media made much of the fact that Som was for the first time bringing the WSS stage play-not the film. The odd English-language touring production had hit the Spanish stage already. Importantly, Ricard Reguant's first Spanish version of W SS (1996-1997) used the film's screenplay, not the stage play.

The two texts are significantly different. The stage play's script is shorter, faster-paced and focused on musical numbers, including a dream ballet sequence which was sacrificed on screen. The different orders of songs in the stage play and screenplay alter the tone of many scenes. On stage, the "Officer Krupke" song took place afternot before - the knife-fight and, consequently, the satire of the song disturbingly came as an anti-climax, at a time of maximum tragic tension, delaying tragic resolution in favor of bitter social critique. On screen, "America" was a bantering piece between Anita and Bernardo, both respectively supported by the Shark girls and boys, exchanging views on the US's combination of opportunity and bigotry. On stage, "America" was sung by the Shark girls and tackled the differences between Puerto Rico-a dangerous, criminal, corrupt and poor wasteland-and the US-by contrast, a promising, welcoming and free land. The dialectics of the play were, for sure, more alienating, less restrained, and less compliant with the classic narrative conventions of Hollywood's Golden Age. Som's publicity strategies strove to bring together audiences nostalgic for the film and audiences hungry for the original Broadway piece. 
The creatives resorted to various strategies to personalize the play. For a start, the Calderón's stage dimensions were too small to accommodate Jerome Robbins' choreography. Designer Ricardo Sánchez Cuerda used the stage depth to display five building blocks which could be arranged differently across and within 15 scenes. A multi-angled and multi-faceted range of combinations afforded opportunities to expand the play's geographic settings and, thus, micro-scenes and interpretive details could be embedded in the story.

David Serrano and A lejandro Serrano's adaptation departed from the original in style as well as in language. Arthur Laurent's register was cautious as became a writer for Broadway shows. The Spanish adapters of Som's production opted for vernacular speech making the play's violence and racism explicit. Dialogue lines were reshuffled and that affected power relations amongst characters. Women were given more prominence through dialogue. For instance, Anybody's-described as a "scrawny teen-age girl" in the stage play script-called herself Paul, her real name being Pauline, which she used to construct an identity fit to stand beside her mates. Similarly, the Jets, originally given nicknames, were given real names so their identities did not appear over-determined. During the balcony scene, Maria-not Tony, as in the original stage playexplains the meaning of Tony's name: "En Puerto Rico, Tony significa A ntonio." Maria wasn't just given the power to ask "What's in a name?"-as in Shakespeare's play-but she appropriated her lover's name to make it part of her own culture.

A similar personalizing style was evident in Barrio's directing style. Unconcerned with replicating a Broadway show, he combined controlled blocking and impromptu actions. Consequently, though the show's pace was not damaged, at times the performance seemed at risk of becoming unruly (as some actors confirm, it almost became so while on tour).

To train the actors-mostly, dancers-to achieve this balance, the first rehearsal week consisted of a workshop to improvise on fragments of Angel-Luis Pujante's translation of $R \& J$. Actors were given Shakespearean fragments according to their character. The exploration moved beyond establishing obvious character parallels-Tony/Romeo, Maria/Juliet, Anita/ Nurse, etc.-and became more complex. All the Jet cast worked on Mercutio's Queen 
Mab speech to find a source of energy on which to ground their group complicity. All the cast worked on Romeo and Juliet's speeches. Thus, every character found herself embedded in the play's tragic love-and-hate dialectic. Supporting roles became less functional, more involved in and committed to the heart of the story. It would take empirical inquiry and interviews to find how Shakespeare-as-safe-conduct ultimately meant anything on stage. Nonetheless, the radically dialectical blocking resulting from the workshop suggests that it was effective. Sometimes, the dialectics was disturbing and emphasized conflict in scenes otherwise taken as mere links between musical numbers. Del Val's Maria's was intensely active, light-hearted, theatrically powerful, vocally impressive, physically masterly in ways approximating Esperanza Campuzano's work in M ontoyas y Tarantos (dir. Vicente Escrivá, 1989), a farccry from Natalie Wood's relatively restrained Maria. Javier Ariano's Tony was relatively boyish but, like Romeo, was sufficiently convinced that the mere strength of his love could transform the world around him. Víctor Gonzalez's Riff was, like Mercutio, at once solid and unstable and, significantly, transformed the "Jet Song" into a persuasion piece-embedded in a leadership conflict-not, as is usually the case, an expository one. The Sharks were unapologetically willing to become the threat the Jets saw in them. The Jets-one of them, Jack, a borderline character who led the "Krupke" song resorting to jazz, modern and contemporary dance moves, which helped both to define character and to estrange audiences-had as much trouble to contain the Sharks as their own brutality. Thus, when they were about to use the youngest member of the gang to rape A nita, the boy was terrified at the event, which, in this case, struck audiences who felt the pain provoked by the Spanish so-called "Manada" (or Wolf Pack)'s collective sexual assault. Poignantly, the scene's musical accompaniment and choreography - a variation on "America" - were simplified and the scene was played as realistic, not stylized.

Overall, Som's WSS brought to Spain the original Broadway production for the first time, but, in the light of production details, Barrios' work breathes with a spirit of its own. It keeps a business-art balance and its mise-en-scène is filled with Shakespearean closereading. Two unfortunate events mark the end of this production's life. Covid-19 forced the company to cancel the Valencian tour. Besides, as members of the crew affirm, it seems that Som will not 
record the show for the Centro de Documentación Teatral. No testimony of this production will be left for students and researchers. Though, as an upcoming screen remake proves, WSS enjoys good health, its production costs will make it difficult for the Spanish theatre industry to stage it again like this in the immediate future.

How to cite this review:

Huertas-Martín, Víctor. Review of West Side Story (2018-2020). Produced by Som Produce (Teatro Calderón, Madrid, 22 December 2018; Teatre Tívoli, Barcelona, 14 February 2020). SED ERI 30 (2020): 183-88.

A uthor's contact: cuccioli25@hotmail.com

Postal address: Dpto. Filología Inglesa - Universidad de Extremadura - Avda. Universidad, s/ n. - 10003 Cáceres - Spain 


\section{Sederi}

\section{Aвоuт SEDERI}

SEDERI, Yearbook of the Spanish and Portuguese Society for English RenaissanceStudies, is an annual publication devoted to current criticism and scholarship on English Renaissance Studies. It is peer-reviewed by external referees, following a double-blind policy. It is published in paper and online, in open-access.

\section{Q uality Assessment and Indexing}

SEDERI is included in the Web of Science, the Arts \& Humanities Citation Index, the MLA International Bibliography, Scopus, Ebsco Host, ProQuest, $\mathrm{ERIH}+$, Annual Bibliography of English Language and Literature (ABELL), Dial net plus, The Spanish Repository for Science and Technology (RECYT), CIRC, Carhus+, Dice (Csic-Cindoc-Aneca), Latindex, and UIrich's Periodicals Directory.

SEDERI's scientific and editorial excellence has been accredited continually by the Spanish Foundation for Science and Technology (FECYT) since 2009. It meets $100 \%$ of the scientific requirements established by Latindex and DiceCindoc.

The Italian National Agency for the Assessment of Research (ANVUR) has ranked SED ERI Y earbook as an «A» journal.

\section{FURTHER INFORMATION}

\section{A reas of interest}

Early Modern English Literature

Early Modern English History and Culture

Early Modern English Language

Restoration English Studies

Early Modern Anglo-Spanish cross-cultural studies

Early Modern Anglo-Portuguese cross-cultural studies 


\section{Editorial process}

Submissions will be sent to two readers for review, following a blind peerreview policy. In case of disagreement, a third report will be decisive. If the paper is accepted for publication, the authors may be asked to consider the readers' suggestions and to bring it into line with our style sheet. The contributions, in its final form, will go through copyediting, layout, and proofreading. Once published, the authors will receive a copy of the issue in which their work is included.

\section{Assessment criteria}

1. Relation to SEDERI areas of interest.

2. Originality and interest of the topic in relation to current research.

3. Knowledge of state of the art and engagement with studies on the topic.

4. Use of methodology of analysis.

5. Depth of discussion of issues, problems and theoretical concerns.

6. Coherence and cohesion in the thread of argument and structure.

7. Interest of data analysed, results obtained, and conclusions reached.

8. Relevance of bibliographical references.

9. Clarity, conciseness and command of the language.

10. Title, abstract and keywords: adequacy, clarity and informative quality.

\section{Submission Information}

Time from submission to decision: 3-4 months Time From decision to publication: 6-9 months Number of readers prior to decision: 2-3 Articles/ notes submitted per year: 20-25 Articles/ notes published per year: 6-10 Information updated on September 2020 
(9) edert

\section{SUBMISSION GUIDELINES FOR SEDERI}

SEDER/ welcomes articles, notes and reviews for its next issue ( $n-31)$ to be published in A utumn 2021.

Submissions should be sent through the SEDERI online submission platform (https:/ / recyt.fecyt.es/ index.php/ SEDY/ about/ submissions). If you are not a user of the SEDERI platform yet, you will need to register as a new user before logging in.

All submissions should be in Word/RTF format.

Please omit any personal information in the file of your paper and make sure the file properties do not show your name.

All the texts submitted must follow SEDERI's style sheet.

Only original research is published by SEDERI. Therefore, we do not consider research pieces that have been published elsewhere (either in print or online) or are under simultaneous consideration with another publisher; translations are not considered either.

Recommended length of contributions:

- Articles: 5,000-8,000 words (including footnotes and references).

- Notes: 2,000-3,500 words (including footnotes and references).

Notes should be pieces of research focusing on a specific point, not needing a broad theoretical or contextual elaboration.

All the submitted ARTICLES and NOTES should include an abstract and $\mathbf{5}$ keywords.

- The abstract (max. 100 words) should convey the essential aspects of your research.

- The 5 keywords (or phrases) are essential to locate your essay in connection with specific topics, authors, periods, and approaches. Avoid being too broad or too narrow.

- They will be published in English, Spanish and Portuguese. If you cannot provide these translations, our translators will do that for you.

- Reviews: 1,000-1,500 words. Books, plays, or films reviewed should have been rel eased in the last two years. 
PeRformance REVIEWS

SEDERI collaborates with www.ReviewingShakespeare.com. Reviews about Shakespearean performances submitted for publication to SEDERI will bealso sent to www.ReviewingShakespeare.com, who will decide on its suitability for publication on their webpage. Inversely, a selection of reviews of Spanish and Portuguese productions of Shakespeare's plays submitted directly to the webpage will be published in SEDERI.

\section{0 riginality and copyright policy}

Only original research is published by SEDERI. Therefore, wedo not consider research pieces that have been published el sewhere (either in print or online) or are under simultaneous consideration with another publisher; translations are not considered either.

Authors will be asked to sign a declaration stating that their contributions have not been previously published, in whole or in part, and do not infringe the copyright or property right of another journal, author or publisher.

Permission for publication of copyrighted material (pictures, photographs, etc.) should be obtained by the author.

The copyright holder of the published contributions is SEDERI .

The hardcopy and an open-access version of the journal will be published simultaneously. The issues will be available online in the SEDERI website (http:/ / www.sederi.org/ yearbook/ ) and other repositories that have signed an agreement with SEDERI.

Those authors who wish to republish or rewrite their contributions for another journal/ book or include the published article in their personal repositories should contact the editors to obtain permission to do so. This will entail citing SEDERI as the original source and sending the editors a copy of the new version.

(2) so

SEDERI, Yearbook of the Spanish and Portuguese Society for English Renaissance Studies

A na Sáez-Hidalgo, Editor

Marta Cerezo Moreno and Isabel Guerrero Llorente, M anaging Editors

María José Mora, Review Editor

Tamara Pérez Fernández, Marta Revilla Rivas, Production E ditors

Dpto. deFilología Inglesa- Universidad deValladolid - Pza. del Campus s/ n

- 47011 Valladolid (Spain)

http:/ / www.sederi.org/ yearbook/

sederiyearbook@yahoo.es 
(9) edert

\section{Style sheet and notes for contributors}

Before sending your manuscript, please make sure that your piece complies with all these requirements:

$\checkmark$ Check the word count (including footnotes and references)

- Articles: 5,000-8,000 words.

- Notes: 2,000-3,500 words.

- Reviews: 1,000-1,500 words.

$\checkmark$ Includean abstract (max. 100 words) and 5 keywords.

Abstracts are published in English, Spanish and Portuguese. If Spanish and/ or Portuguese are not your native language, please let us know.

$\checkmark$ Format, citations, and references follow SED ERI's style sheet.

$\checkmark$ Use American English spelling and punctuation.

$\checkmark$ Remove personal details from the file of the contribution and from the properties of the file.

$\checkmark$ Make sure your name, affiliation, address and other details are only provided separately and NOT included in the file of your essay. During the online submission process, you will be asked to record these details in the platform.

$\checkmark$ Originality: the research piece has not been previously published (either in print or online) and is not under simultaneous consideration with another publisher.

$\checkmark$ Copyright: no copyright of another journal, author or publisher is infringed.

$\checkmark$ Obtain permissions for publication of copyrighted material (pictures, photographs, etc.).

Note that non-standard ASCII characters or unusual fonts, particularly special characters in Old and Middle English, Phonetics or Greek, illustrations, graphics, tables, pictures, etc. must be consulted with the editors. 


\section{FORMAT}

MARGINS: 2,5 cm for all the margins.

Font: Times New Roman 12 throughout the whole text (including title, subtitles, notes, quotations, etc.)

NB: N on-standard ASCII characters or unusual fonts, particularly special characters in Old and Middle English, Phonetics or Greek, illustrations, graphics, tables, pictures, etc. must be consulted with the editors.

HEADINGSAND SUBHEADINGS should be capitalized in the same font and size.

LINE SPACING: 1'5.

UseFootNotes instead of endnotes.

Please avoid HEADERS, FOOTERS, and PAGE NUMBERS.

SPELLING AND PUNCTUATION: American English

QUOTATIONS:

- Short quotations (up to 40 words) should be incorporated into the text, using quotation marks (" ").

- Longer quotations should be indented without quotation marks and no italics.

BIBLIOGRAPHY

SEDERI follows the $17^{\text {th }}$ edition of the Chicago Manual of Style (CMS). For a quick citation guide, see:

http:/ / www.chicagomanual ofstyle.org/ tools_citationguide.html

\section{References within the text and in footnotes}

SEDERI uses the author-date citation system, that is, the identification of sources is given in parenthetical citation in the text as they are mentioned or needed for support in the text.

- The information in parenthesis should include: author + publication year + page number(s).

Example: (Owen 1996, 27)

- If the author's name is mentioned in the text, there is no need to repeat it in the citation.

Example: ... Owen $(1996,27)$ noted the importance of satire... 


$$
\text { (9) ederi }
$$

Footnotes are intended for providing further detail / commentary or for explanatory purposes.

\section{List of bibliographical references}

A list of works cited should be provided at the end of the essay under the heading "References," following the Chicago Manual of Style.

Find below some examples of bibliographical citation for the reference list:

BOOKS

Carnegie, David, and Gary Taylor, eds. 2012. The Quest for Cardenio: Shakespeare, Fletcher, Cervantes, and the Lost Play. Oxford: Oxford University Press.

Fuchs, Barbara. 2013. The Poetics of Piracy: Emulating Spain in English Literature. Philadelphia: University of Pennsylvania Press.

EDITED/ TRANSLATED BOOKS

Sidney, Philip. 1992. A strophil y Stella. Edited by Fernando Galván Reula. Madrid: Cátedra.

JOURNAL ARTICLES

Steggle, Matthew. 2019. “John and Laurence Dutton, Leaders of the Queen's Men." Shakespeare Q uarterly 70 (1): 32-51.

Quinn, William A. 2011. "Red Lining and Blue Penciling The Kingis Q uair." Studies in Philology 108: 189-214. DOI: 10.1353/ sip.2011.0011

BOOK CHAPTERS

Snyder, Susan. 2001. "The Genres of Shakespeare's Plays." In The Cambridge Companion to Shakespeare, edited by Margreta deGrazia and Stanley Wells, 83-97. Cambridge: Cambridge University Press.

See more examples in our latest issues in http:/ / www .sederi.org/ yearbook/

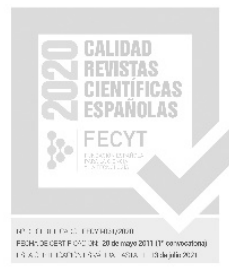

